Prepared in cooperation with the Oklahoma Water Resources Board

\title{
Hydrologic Drought of Water Year 2006 Compared with Four Major Drought Periods of the 20th Century in Oklahoma
}

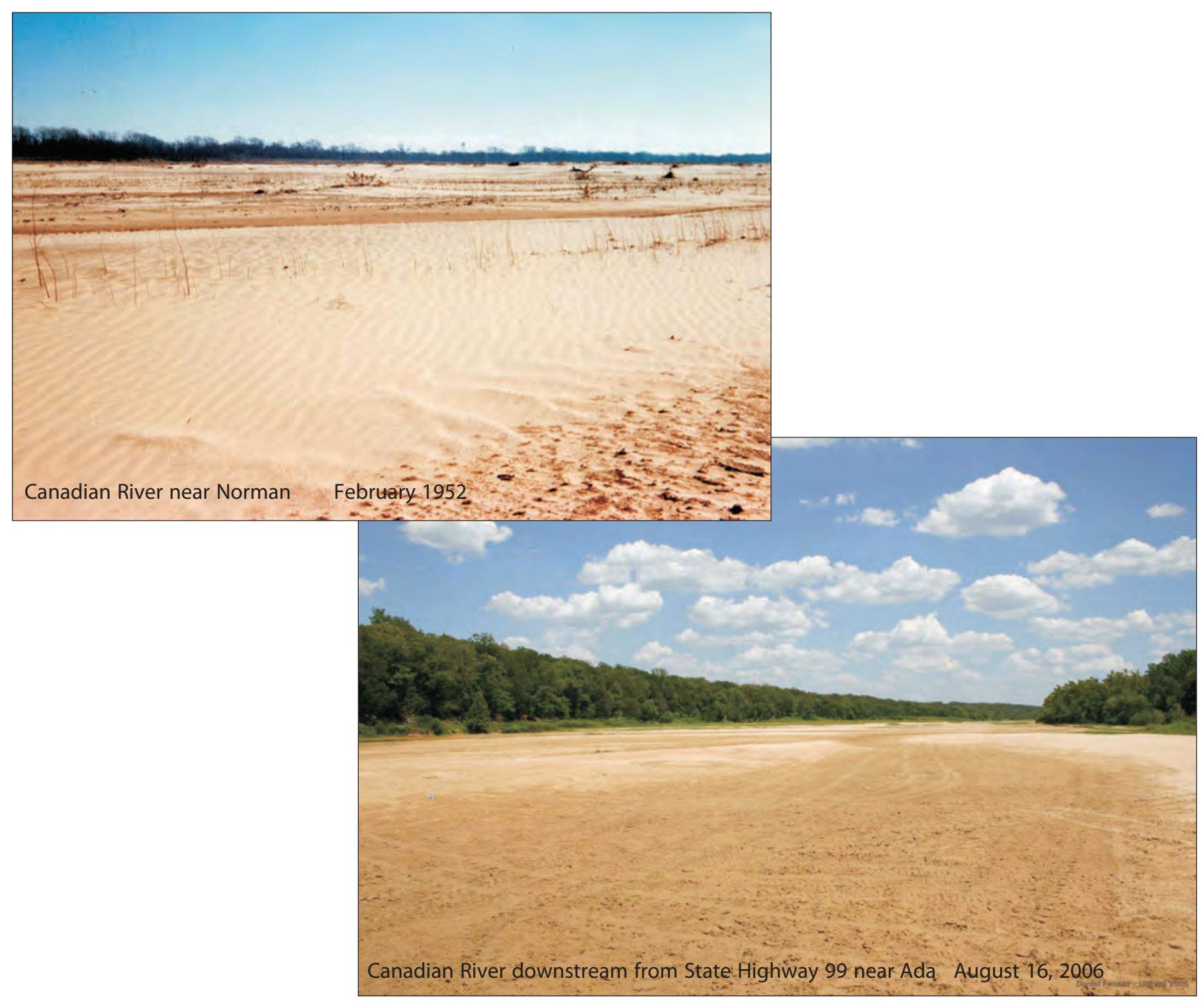

Scientific Investigations Report 2008-5199 
Front Cover: Picture One shows wind ripples and river silts, Canadian River near Norman, Cleveland County, Oklahoma, taken February 1952. Photographer: W.B. Hamilton, from U.S. Geological Survey Photographic Library.

Picture Two shows the dry Canadian River near Ada, Pontotoc County, Oklahoma, downstream from State Highway 99, taken August 16, 2006. Photographer: Daniel Fenner, U.S. Fish and Wildlife Service. 


\section{Hydrologic Drought of Water Year 2006 Compared with Four Major Drought Periods Of the 20th Century in Oklahoma}

By Robert L. Tortorelli

Prepared in cooperation with the Oklahoma Water Resources Board

Scientific Investigations Report 2008-5199 


\section{U.S. Department of the Interior DIRK KEMPTHORNE, Secretary}

\section{U.S. Geological Survey \\ Mark D. Myers, Director}

U.S. Geological Survey, Reston, Virginia: 2008

This and other USGS information products are available at:
http://store.usgs.gov/
U.S. Geological Survey
Box 25286 , Denver Federal Center
Denver, CO 80225
To learn about the USGS and its information products visit http://www.usgs.gov/
1-888-ASK-USGS

Any use of trade, product, or firm names is for descriptive purposes only and does not imply endorsement by the U.S. Government.

Although this report is in the public domain, permission must be secured from the individual copyright owners to reproduce any copyrighted materials contained within this report.

Suggested citation:

Tortorelli, R.L., 2008, Hydrologic drought of Water Year 2006 compared with four major drought periods of the 20th century in Oklahoma: U.S. Geological Survey Scientific Investigations Report 2008-5199, 46 p. 


\section{Contents}

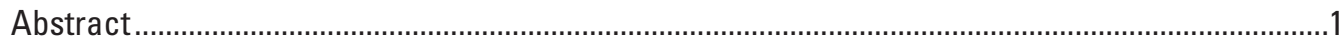

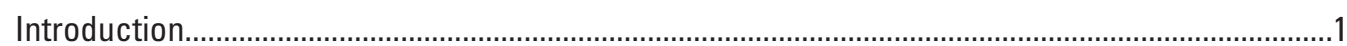

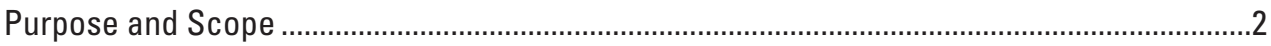

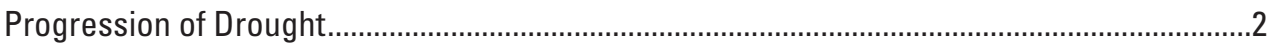

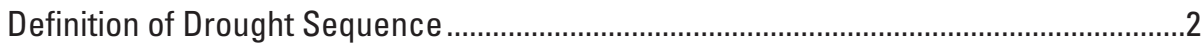

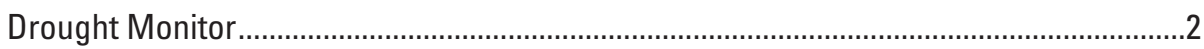

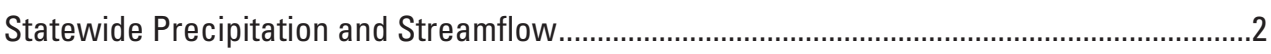

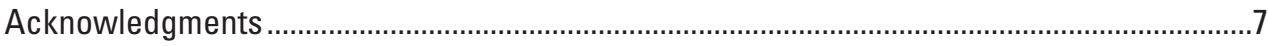

Precipitation by Climate Division ...............................................................................................

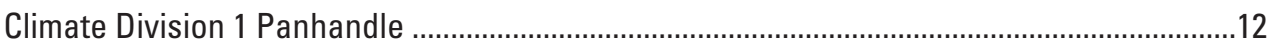

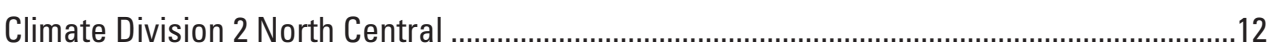

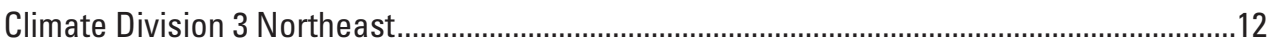

Climate Division 4 West Central .........................................................................................12

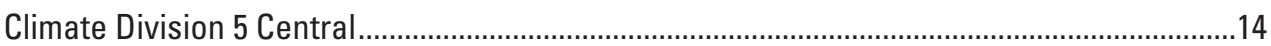

Climate Division 6 East Central .......................................................................................14

Climate Division 7 Southwest ..........................................................................................

Climate Division 8 South Central ..........................................................................................

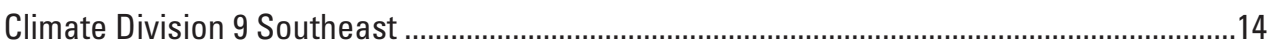

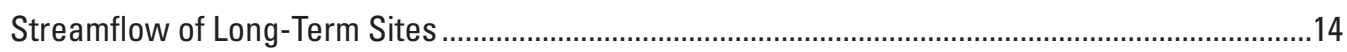

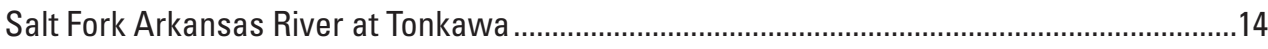

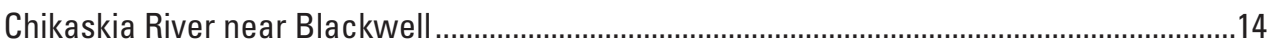

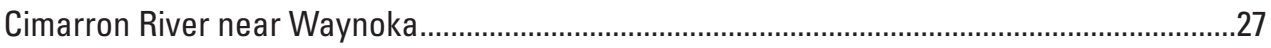

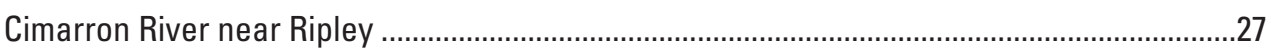

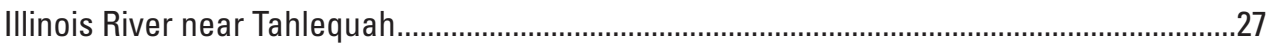

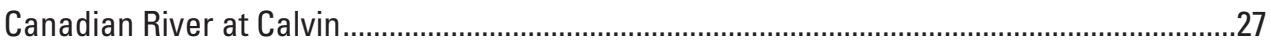

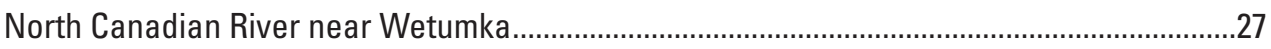

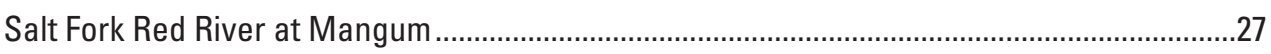

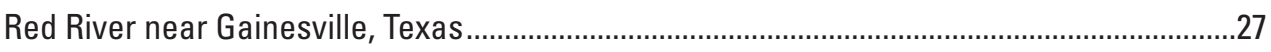

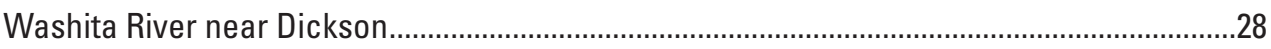

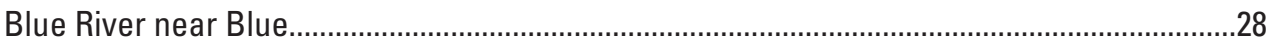

Red River at Arthur City, Texas ......................................................................................28

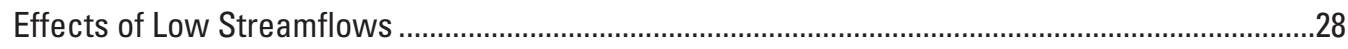

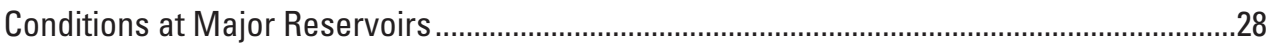

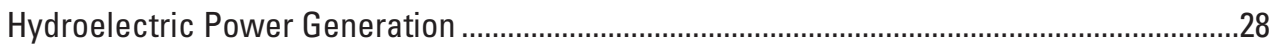

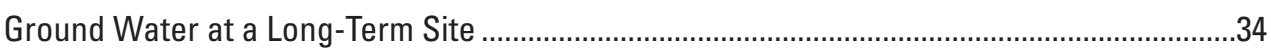

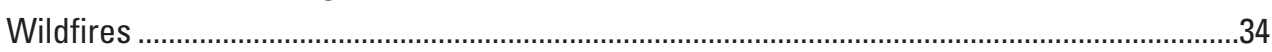

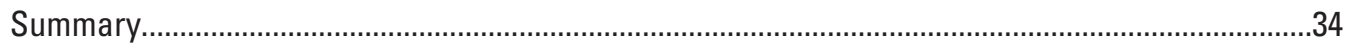

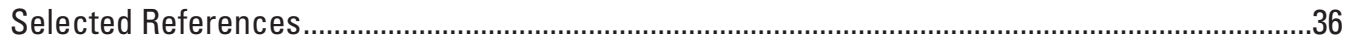

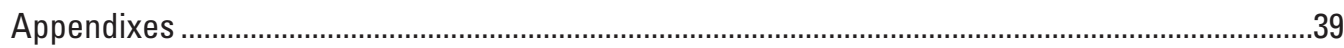

1-7. Photographs showing:

1. Salt Fork of Arkansas River at Tonkawa (0751000), showing low flow, 30 cubic feet per second, looking upstream from U.S. Highway 77 bridge, August 6, 2006..........41 
2. Chikaskia River near Blackwell (07152000), showing low flow, 74 cubic feet per second, looking downstream from State Highway 11 bridge, August 6, 2006.

3. Cimarron River near Waynoka (07158000), showing low flow, 0.17 cubic foot per second, looking downstream from U.S. Highway 281 bridge, August 9, 2006.

4. Cimarron River near Ripley (07161450), showing low flow, 55 cubic feet per second, looking upstream toward State Highway 33 bridge, August 11, 2006

5. Canadian River upstream to downstream, August 11, 2006: $(A)$ near Thomas, showing no flow, looking upstream from State Highway 33 bridge $(B)$ at Bridgeport (07228500), showing low flow and pools, 2.9 cubic feet per second, looking upstream from U.S. Highway 281 bridge

5. Canadian River upstream to downstream, August 11, 2006: (C) near Union City, showing no flow and pools, looking upstream from State Highway 81 bridge $(D)$ at Purcell (07229200), showing low flow and pools, 4.2 cubic feet per second, looking upstream from U.S. Highway 77 bridge.

5. Canadian River upstream to downstream: $(E)$ near Wanette, showing no flow, looking upstream from State Highway 102 bridge, August 11, 2006 (F) near Ada, showing no flow, looking downstream from State Highway 99 bridge, August 16, 2006.

6. Washita River near Dickson (07331000), showing low flow and pools, 5.7 cubic feet per second, looking downstream from U.S. Highway 177 bridge, August 22, 2006

7. Lake Altus at Lugert (07302500), showing very low lake elevation, 7.7 percent of conservation storage, looking upstream from dam, August 22, 2006. 46

\section{Figures}

1. Sequence of drought development

2. Maps showing monthly Drought Monitor Graphs, November 1, 2005, through October 3, 2006

3-4. Graphs showing:

3. Oklahoma statewide precipitation showing the annual departure from the long-term statewide median of 33.51 inches and a 5-year weighted average line for water years $1925-2006$..

4. Oklahoma statewide runoff showing the annual departure from the long-term statewide median of 3 inches and a 5-year weighted average line for water years 1925-2006.

5. Maps showing regional streamflow patterns Water Year 2006

6. Map showing percentage of stations below normal streamflow since January 16, 2001, through February 1, 2008, in Oklahoma

7. Map showing National Weather Service Climate Divisions in Oklahoma.......................12

8-9. Maps showing:

8. Oklahoma (A) percent of normal rainfall, Water Year 2006 (B) departure from normal rainfall, Water Year 2006

9. Selected long-term streamflow-gaging stations in Oklahoma and Canadian River photograph locations. 
10-21. Graphs showing:

10. Salt Fork Arkansas River at Tonkawa $(A)$ annual departure from long-term median annual streamflow, water years 1942-2006 (B) comparing daily-mean streamflow of Water Year 2006 and long-term daily-mean streamflow, water years 1942-2006.

11. Chikaskia River near Blackwell (A) annual departure from long-term median annual streamflow, water years 1937-2006 (B) comparing daily-mean streamflow of Water Year 2006 and long-term daily-mean streamflow, water years 1937-2006.

12. Cimarron River near Waynoka $(A)$ annual departure from long-term median annual streamflow, water years 1938-2006 (B) comparing daily-mean streamflow of Water Year 2006 and long-term daily-mean streamflow, water years 1938-2006.

13. Cimarron River near Ripley (A) annual departure from long-term median annual streamflow, water years 1940-2006 (B) comparing daily-mean streamflow of Water Year 2006 and long-term daily-mean streamflow, water years 1940-2006. Includes streamflow record 1940-87 from nearby station 0716100, Cimarron River at Perkins.

14. Illinois River near Tahlequah (A) annual departure from long-term median annual streamflow, water years 1936-2006 (B) comparing daily-mean streamflow of Water Year 2006 and long-term daily-mean streamflow, water years 1936-2006.

15. Canadian River at Calvin $(A)$ annual departure from long-term median annual streamflow, water years 1939-2006 (B) comparing daily-mean streamflow of Water Year 2006 and long-term daily-mean streamflow, water years 1939-2006.

16. North Canadian River near Wetumka (A) annual departure from long-term median annual streamflow, water years 1938-2006 (B) comparing daily-mean streamflow of Water Year 2006 and long-term daily-mean streamflow, water years 1938-2006

17. Salt Fork Red River at Mangum (A) annual departure from long-term median annual streamflow, water years 1938-2006 (B) comparing daily-mean streamflow of Water Year 2006 and long-term daily-mean streamflow, water years 1938-2006.

18. Red River near Gainesville, Texas, (A) annual departure from long-term median annual streamflow, water years 1937-2006 (B) comparing daily-mean streamflow of Water Year 2006 and long-term daily-mean streamflow, water years 1937-2006.

19. Washita River near Dickson (A) annual departure from long-term median annual streamflow, water years 1929-2006 (B) comparing daily-mean streamflow of Water Year 2006 and long-term daily-mean streamflow, water years 1929-2006.

20. Blue River near Blue $(A)$ annual departure from long-term median annual streamflow, water years 1937-2006 (B) comparing daily-mean streamflow of Water Year 2006 and long-term daily-mean streamflow, water years 1937-2006.

21. Red River at Arthur City, Texas, (A) annual departure from long-term median annual streamflow, water years 1945-2006 (B) comparing daily-mean streamflow of Water Year 2006 and long-term daily-mean streamflow, water years 1945-2006. 
22. Map showing locations of selected major lakes and reservoirs in Oklahoma and percent of Conservation Storage as of October 4, 2006.

23. Graph showing Fittstown ground-water well, comparing daily water levels for Water Year 2006 and long-term mean-daily water levels, water years 1981-2006. 36

\section{Tables}

1. Summary of precipitation at Climate Divisions in Oklahoma comparing the median of mean annual precipitation during water years 1925-2006 with average annual precipitation during periods of previous documented hydrologic droughts and the recent hydrologic drought period.

2. Summary of streamflow conditions at selected long-term streamflow-gaging stations in Oklahoma comparing the median of mean annual streamflow with average annual streamflow during periods of previous documented hydrologic droughts and the recent hydrologic drought period.

3. Storage in selected major Oklahoma lakes and reservoirs during October 4, 2006, by National Weather Service Climate Division, and comparison with December 21, 2005, and May 24, 2006, storage.

4. Comparison of hydroelectric power generation at selected Oklahoma hydroelectric plants between Calendar Year 2005 and Water Year 2006.

\section{Conversion Factors and Datums}

\begin{tabular}{|c|c|c|}
\hline Multiply & By & To obtain \\
\hline \multicolumn{3}{|c|}{ Length } \\
\hline inch (in.) & 2.54 & centimeter $(\mathrm{cm})$ \\
\hline inch (in.) & 25.4 & millimeter (mm) \\
\hline foot $(\mathrm{ft})$ & 0.3048 & meter $(\mathrm{m})$ \\
\hline \multicolumn{3}{|c|}{ Area } \\
\hline square mile $\left(\mathrm{mi}^{2}\right)$ & 2.590 & square kilometer $\left(\mathrm{km}^{2}\right)$ \\
\hline \multicolumn{3}{|c|}{ Volume } \\
\hline acre-foot (acre-ft) & 1,233 & cubic meter $\left(\mathrm{m}^{3}\right)$ \\
\hline \multicolumn{3}{|c|}{ Flow rate } \\
\hline cubic foot per second $\left(\mathrm{ft}^{3} / \mathrm{s}\right)$ & 0.02832 & cubic meter per second $\left(\mathrm{m}^{3} / \mathrm{s}\right)$ \\
\hline \multicolumn{3}{|c|}{ Energy } \\
\hline gigawatt-hour (GWh) & $3.6 \times 10^{12}$ & joule $(\mathrm{J})$ \\
\hline
\end{tabular}

Vertical coordinate information is referenced to the North American Vertical Datum of 1988 (NAVD 88).

Horizontal coordinate information is referenced to the North American Datum of 1983 (NAD 83).

Altitude, as used in this report, refers to distance above the vertical datum.

Water year is the 12-month period October 1 through September 30, designated by the calendar year in which the water year ends. 


\title{
Hydrologic Drought of Water Year 2006 Compared With Four Major Drought Periods of the 20th Century In Oklahoma
}

\author{
By Robert L. Tortorelli
}

\section{Abstract}

Water Year 2006 (October 1, 2005, to September 30, 2006) was a year of extreme hydrologic drought and the driest year in the recent 2002-2006 drought in Oklahoma. The severity of this recent drought can be evaluated by comparing it with four previous major hydrologic droughts, water years 1929-41, 1952-56, 1961-72, and 1976-81. The U.S. Geological Survey, in cooperation with the Oklahoma Water Resources Board, completed an investigation to summarize the Water Year 2006 hydrologic drought and compare it to the four previous major hydrologic droughts in the 20th century.

The period of water years 1925-2006 was selected as the period of record because before 1925 few continuous record streamflow-gaging sites existed and gaps existed where no streamflow-gaging sites were operated. Statewide annual precipitation in Water Year 2006 was second driest and statewide annual runoff in Water Year 2006 was sixth driest in the 82 years of record.

Annual area-averaged precipitation totals by the nine National Weather Service Climate Divisions from Water Year 2006 are compared to those during four previous major hydrologic droughts to show how rainfall deficits in Oklahoma varied by region. Only two of the nine climate divisions, Climate Division 1 Panhandle and Climate Division 4 West Central, had minor rainfall deficits, while the rest of the climate divisions had severe rainfall deficits in Water Year 2006 ranging from only 65 to 73 percent of normal annual precipitation.

Regional streamflow patterns for Water Year 2006 indicate that Oklahoma was part of the regionwide below-normal streamflow conditions for Arkansas-White-Red River Basin, the sixth driest since 1930. The percentage of long-term stations in Oklahoma (with at least 30 years of record) having below-normal streamflow reached 80 to 85 percent for some days in August and November 2006.

Twelve long-term streamflow-gaging sites with periods of record ranging from 62 to 78 years were selected to show how streamflow deficits varied by region. The hydrologic drought worsened going from north to south in Oklahoma, ranging from 45 percent in the north, to just 14 percent in eastcentral Oklahoma, and 20 percent of normal annual streamflow in the southwest.

The low streamflows resulted in only 86.3 percent of the statewide conservation storage available at the end of the water year in major reservoirs, and 7 to 47 percent of hydroelectric power generation at sites in Oklahoma in Calendar Year 2005.

\section{Introduction}

Water Year 2006 (October 1, 2005, to September 30, 2006) was a year of extreme hydrologic drought and the driest year in the recent 2002-2006 drought in Oklahoma. A sense of the severity of this recent drought can be evaluated by comparing Water Year 2006 hydrologic drought with four previous major hydrologic droughts, water years 1929-41, 1952-56, 1961-72, and 1976-81. The effect of the drought varies in different regions of the state. Data from several long-term streamflow-gaging stations are available to assess the effect of the hydrologic drought of Water Year 2006 in Oklahoma.

Hydrologic drought is associated with the effects of periods of precipitation deficits on surface or subsurface water supply. The frequency and severity of hydrologic drought is defined on a watershed or river basin scale. Water in the hydrologic storage systems, rivers and reservoirs, commonly has multiple and competing purposes including flood control, irrigation, recreation, navigation, hydropower, and wildlife habitat. Competition for this water escalates during drought, and conflicts between water users increase substantially (National Drought Mitigation Center, 2006a).

The U.S. Geological Survey (USGS), in cooperation with the Oklahoma Water Resources Board, completed an investigation to summarize the Water Year 2006 hydrologic drought and compare it to the four previous major hydrologic droughts in the 20th century. 


\section{Purpose and Scope}

The purpose of this report is to describe and document the Water Year 2006 hydrologic drought in Oklahoma and compare it to four previous major hydrologic droughts, water years 1929-41, 1952-56, 1961-72, and 1976-81.

A brief introduction includes (1) a definition of drought sequence, (2) a presentation of monthly nationwide drought monitor graphics for Water Year 2006, and (3) a comparison of annual statewide total precipitation and statewide streamflow runoff from water years 1925-2006 in Oklahoma with the four previous major hydrologic droughts in the 20th century highlighted. Annual area-averaged precipitation totals for Water Year 2006 for the nine National Weather Service Climate Divisions in Oklahoma are compared to precipitation during four previous major hydrologic droughts in the 20th century to show how rainfall deficits varied by region. Next the mean annual streamflow during Water Year 2006 at 12 long-term streamflow-gaging sites are compared to streamflow during four previous major hydrologic droughts in the 20th century to show how streamflow deficits varied by region. The effects of low streamflows are discussed to include (1) conservation storage at major reservoirs throughout the state, (2) hydroelectric power generation, (3) ground-water levels at a long-term site, and (4) wildfires.

The effects of the hydrologic drought of Water Year 2006 on agriculture are beyond the scope of this report and a discussion can be found in Oklahoma Agricultural Statistics 2007 (National Agricultural Statistics Service, 2007).

\section{Progression of Drought}

\section{Definition of Drought Sequence}

The drought sequence development is illustrated in figure 1. The start of a drought begins with precipitation deficiency, high temperatures and winds, and low humidity, collectively resulting in "meteorological" drought. As soil moisture is reduced and plants are stressed, "agricultural" drought is experienced. If the drought continues for several seasons, streamflow is reduced to critical levels and "hydrologic" drought results (Oklahoma Water Resources Board, 2007a; National Drought Mitigation Center, 2006a).

\section{Drought Monitor}

The U.S. Drought Monitor is a graphic depiction of broad-scale drought in the United States displayed on the National Drought Mitigation Center web page (National Drought Mitigation Center, 2007). Agricultural and hydrologic drought effects are displayed on a weekly graphic accompanied by tabular data and general regional narratives for that week.

Figure 2 shows the progression of the Water Year 2006 drought with 12 monthly Drought Monitor graphs from
November 1, 2005, to October 3, 2006. The hydrologic drought of Water Year 2006 in Oklahoma is shown getting steadily worse from November through March, improving with some spring and summer rains from April through the beginning of July and then the drought is worst in August. Conditions improved in September and October.

\section{Statewide Precipitation and Streamflow}

Precipitation and runoff plots help to characterize the duration and severity of hydrologic drought by comparing annual statewide precipitation and runoff departures from long-term median values. Annual departures are shown as positive bars when annual departures exceed the long-term median and as negative bars when annual departures are less than the long-term median. Thus departures that are consistently negative over several years provide a measure of drought duration or persistence, while the magnitude of individual departures provides a measure of severity. Negative departure of runoff also can be characterized as runoff deficits.

The period of water years 1925-2006 was selected as the period of record for long-term drought analysis. Few continuous record streamflow-gaging sites existed and there were record year gaps where no streamflow-gaging sites were operated before 1925 (U.S. Geological Survey, 2007a). The four previous major hydrologic drought periods, water years 1929-41, 1952-56, 1961-72, and 1976-81 were identified from the statewide runoff plot and modified from a previous drought report by Tortorelli and others (1991). The 2002-2006 hydrologic drought period was identified from the statewide runoff plot.

Figures 3 and 4 show how annual statewide precipitation and annual statewide median runoff compare during water years 1925-2006. First, the statewide annual mean precipitation for each water year of the period (National Climatic Data Center, 2007a) is plotted as the departure from the median annual precipitation for the period ("normal" annual precipitation, blue line), and a 5-year weighted-average departure precipitation is plotted as a red line (fig. 3). The selected drought periods are indicated by different colored annual bars. Water Year 2006 was second driest in the 82 years of record from 1925-2006.

Second, the statewide annual median runoff for each water year of the period (U.S. Geological Survey, 2007a) is plotted as the departure from the median annual runoff for the period ("normal" annual runoff, blue line), and a 5-year weighted-average departure runoff is plotted as a red line (fig. 4). The selected drought periods are indicated by different colored annual bars. Based on runoff, Water Year 2006 was sixth driest in the 82 years of record from 1925-2006.

Wetter years plot above the median line and drier years plot below the median line. Water Year 2006 then can be compared to the dry years in the four previous major hydrologic droughts by depth of the bars. The length and severity of the water year 2002-2006 drought period also can be compared 


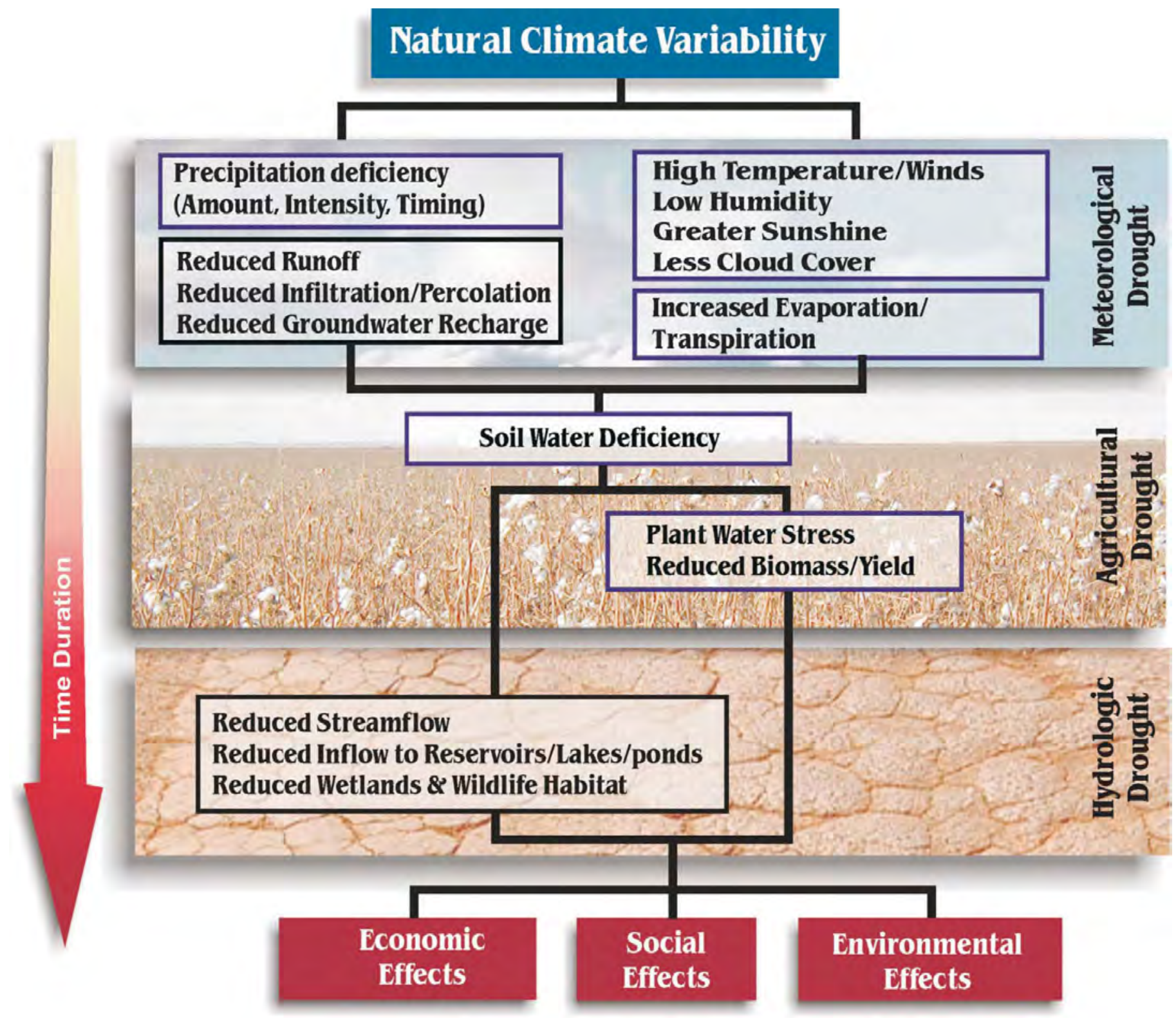

Figure 1. Sequence of drought development (Oklahoma Water Resources Board, 2007a; modified from National Drought Mitigation Center, 2006a) 


\section{U.S. Drought Monitor}

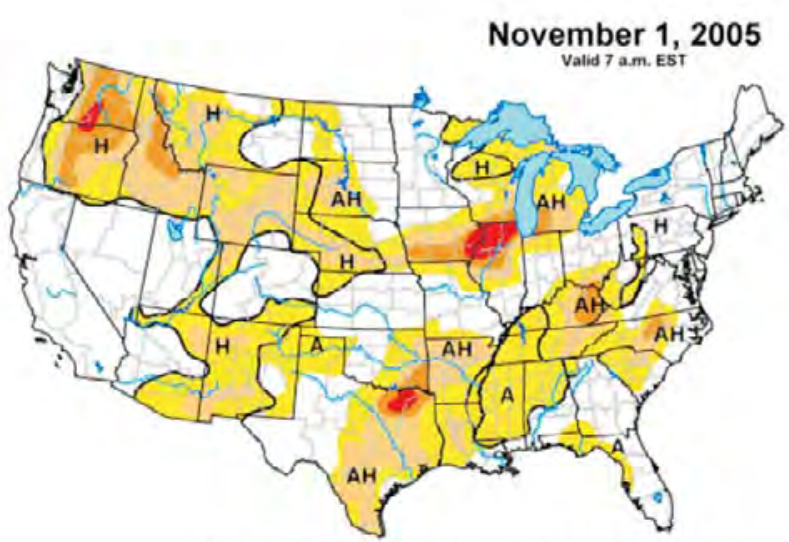

Released Thursday, November 3, 2005 Author: R. Heim/L. Love-Brotak, NOAANESDIS/NCDC

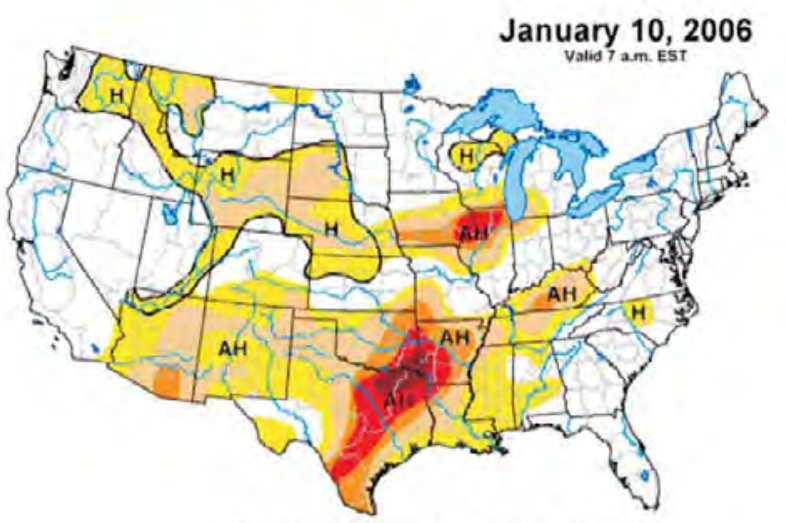

Released Thursday, January 12, 2006 Author: Dougtas Le Comte, CPC/NOAA

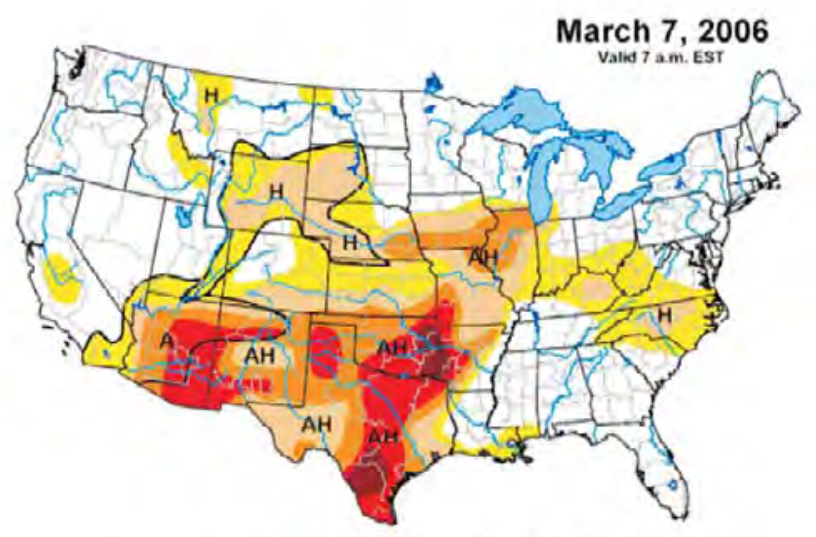

Released Thursday, March 9, 2006 Author: Brian Fuchs, National Drought Mitigation Center

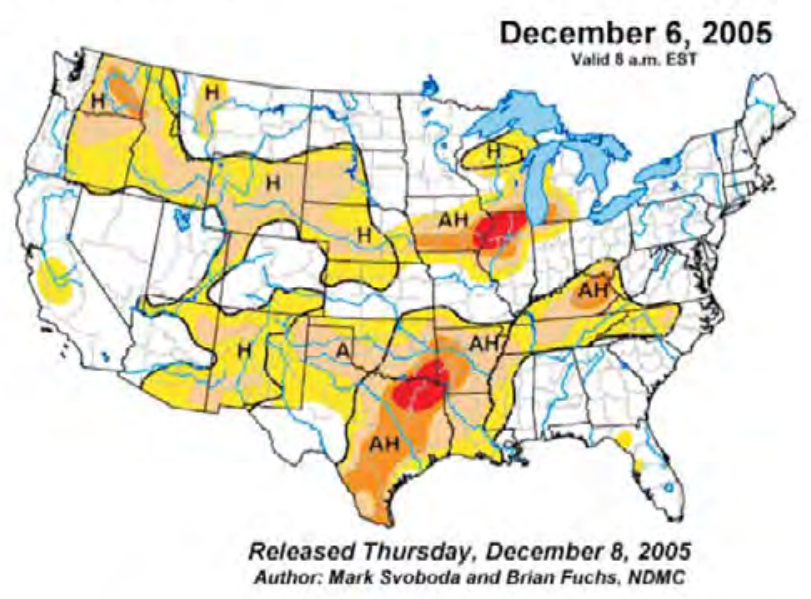

February 7, 2006

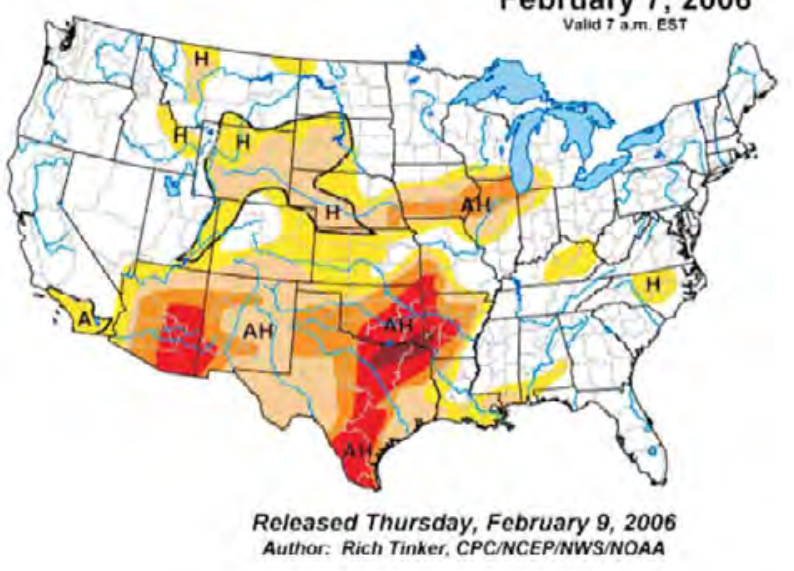

April 4, 2006

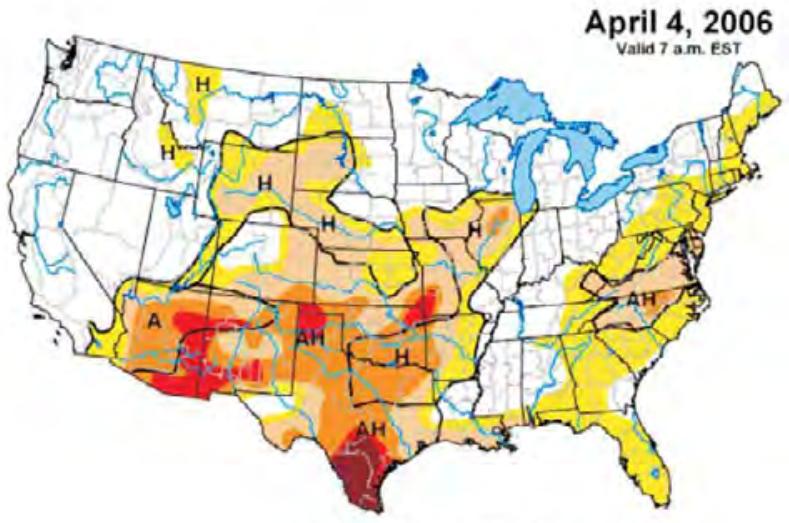

Released Thursday, April 6, 2006 Author: Douglas Le Comte, CPC/NOAA

\section{Drousht Impact Types. \\ $\sim$ Delineates dominant impacts \\ $A=$ Agricultural (crops, pastures \\ $H=$ Hydrological (waster)

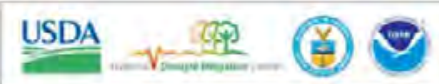

Figure 2. Monthly Drought Monitor Graphs, November 1, 2005, through October 3, 2006, (National Drought Mitigation Center, 2007) - Continued 


\section{U.S. Drought Monitor}

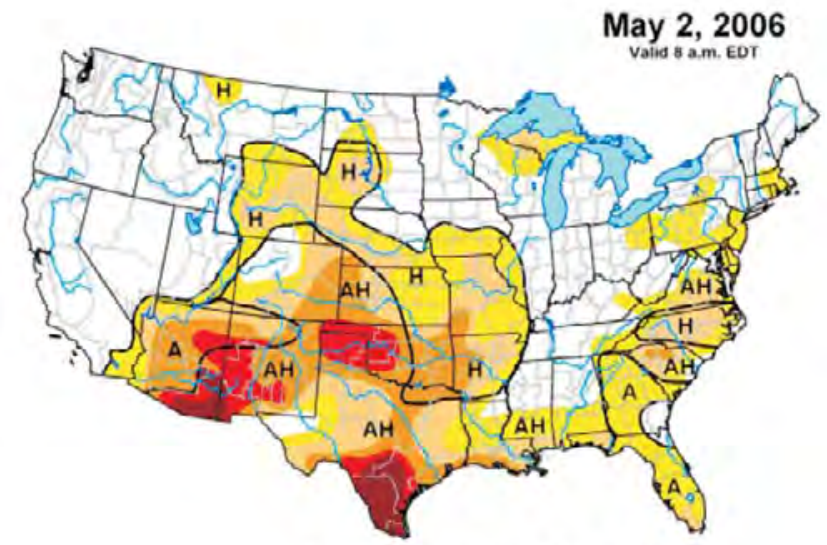

Released Thursday, May 4, 2006

Author: Mark Svoboda, National Drought Mitigation Center

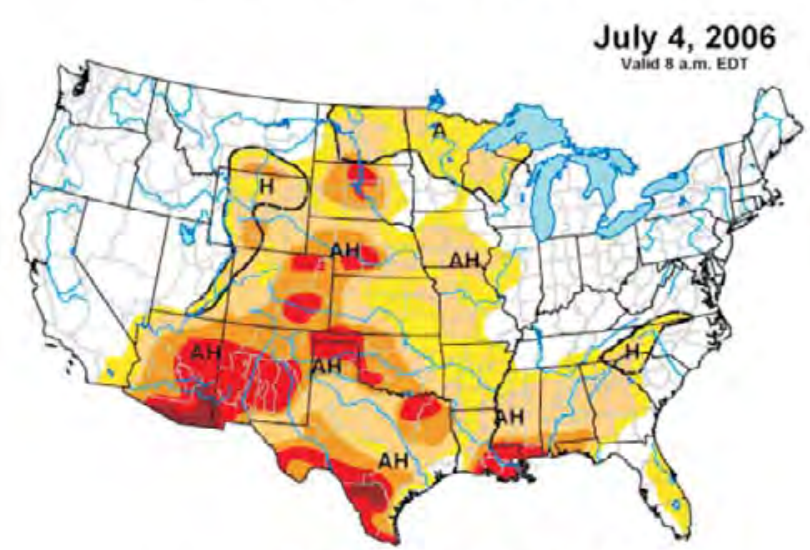

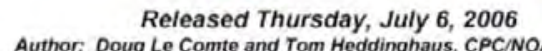

September 5, 2006

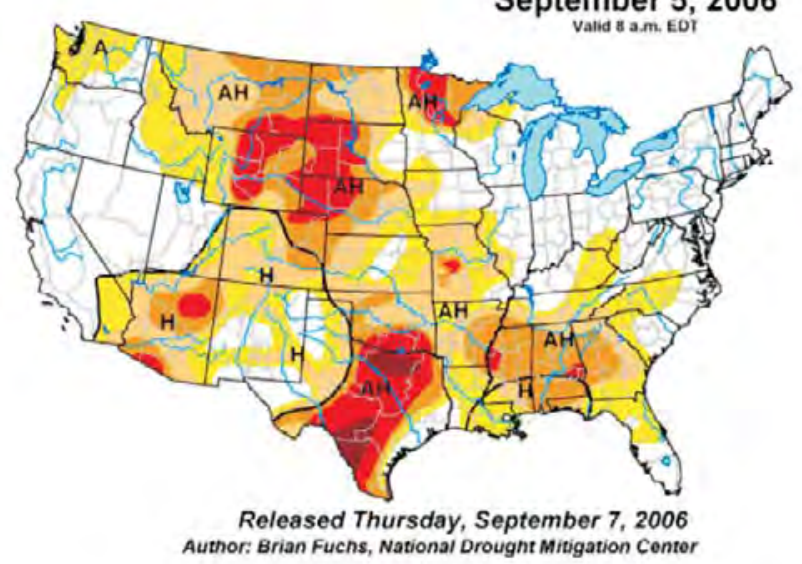
Author: Brian Fuchs, National Drought Mitigation Centor

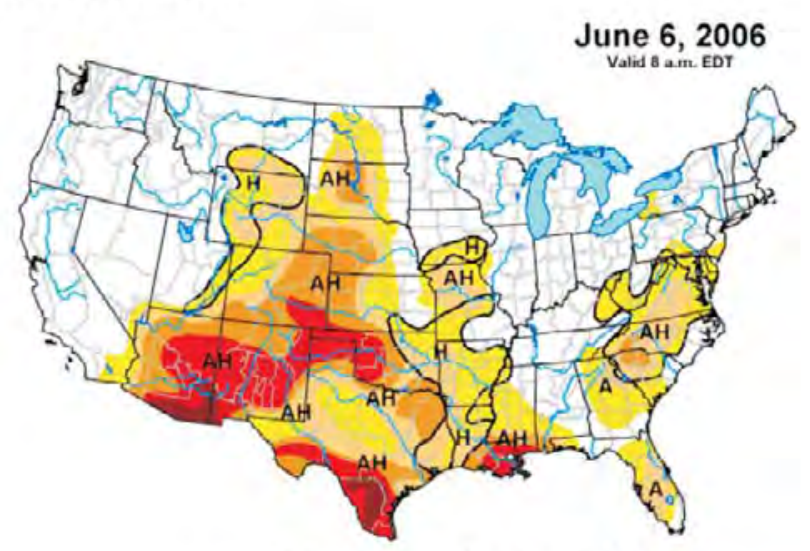

Released Thursday, June 8, 2006 Author: Brian Fuchs, National Drought Mitigation Center

August 8, 2006

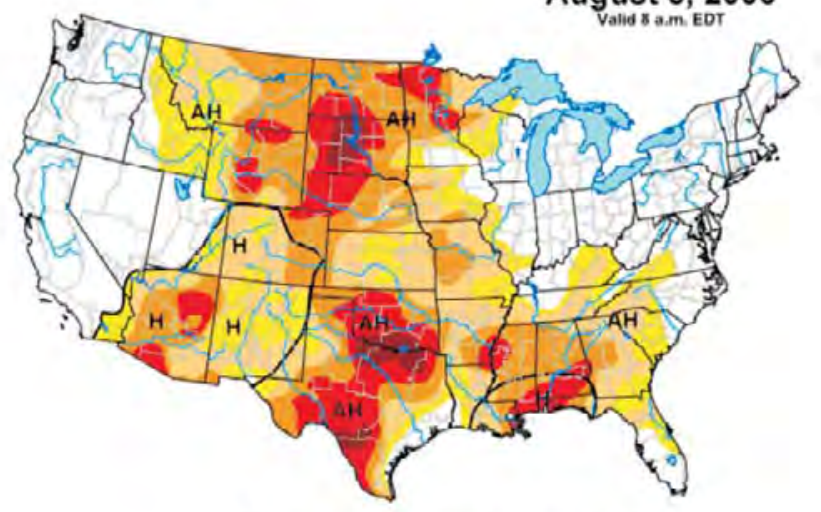

Released Thursday, August 10, 2006 Author: Rich Tinker, Climate Prediction Center, NOAA

October 3, 2006

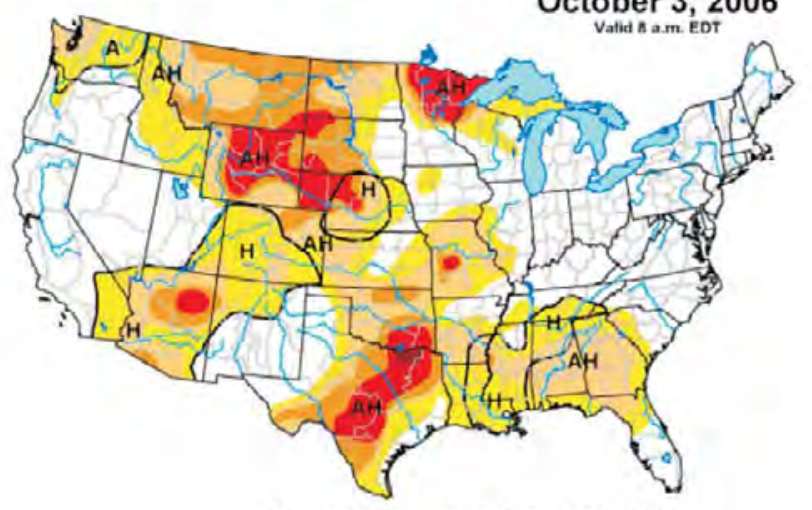

Released Thursday, October 5, 2006 Author: Rich Tinker. Climate Prediction Center. NOAA

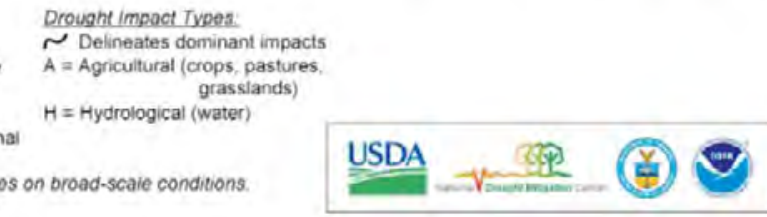

Figure 2. Monthly Drought Monitor Graphs, November 1, 2005, through October 3, 2006, (National Drought Mitigation Center, 2007). 


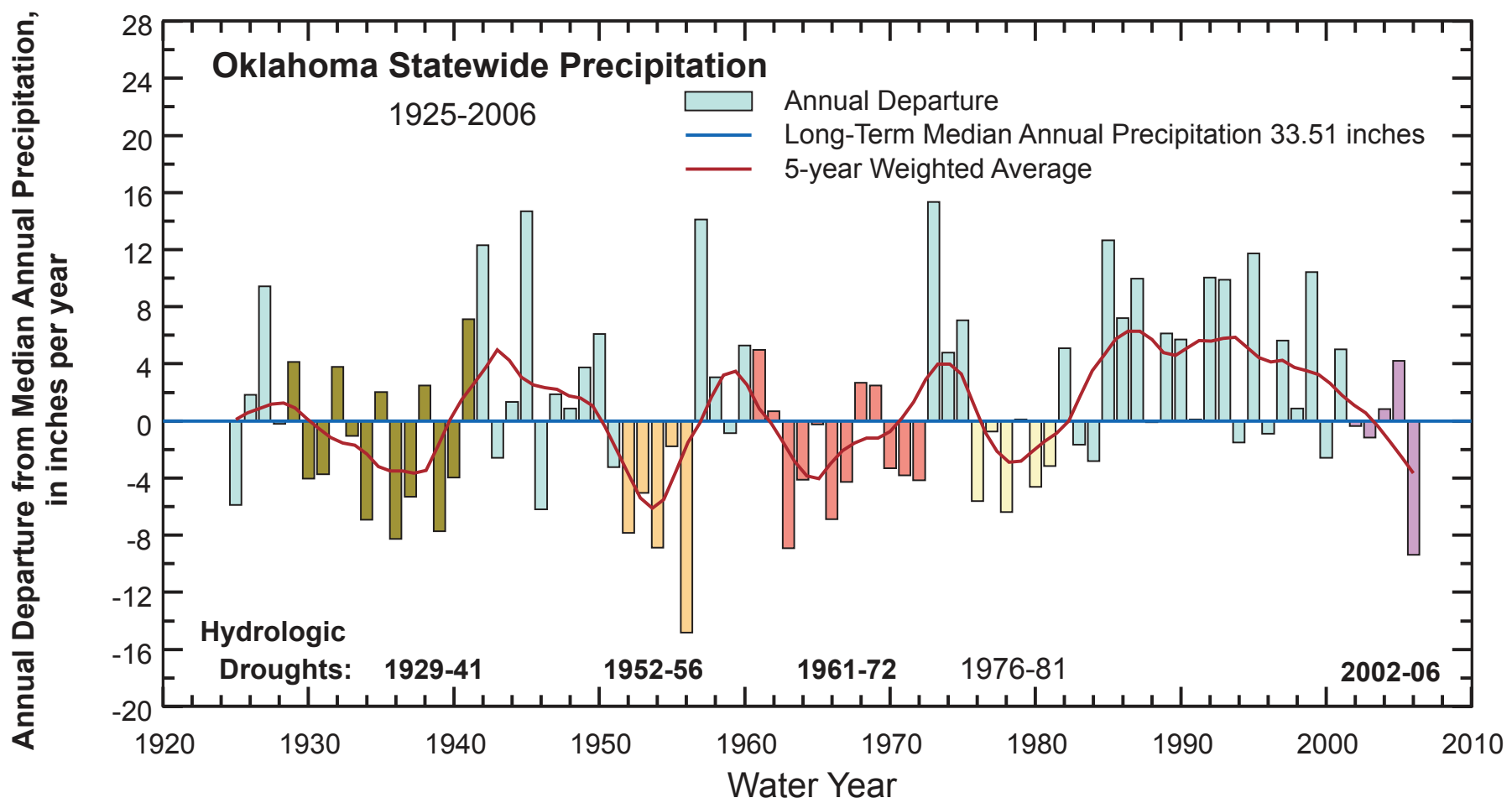

Figure 3. Oklahoma statewide precipitation showing the annual departure from the long-term statewide median of 33.51 inches (blue line) and a 5-year weighted average line for water years 1925-2006 (red line). Wetter years plot above the median line and drier years plot below the median line.

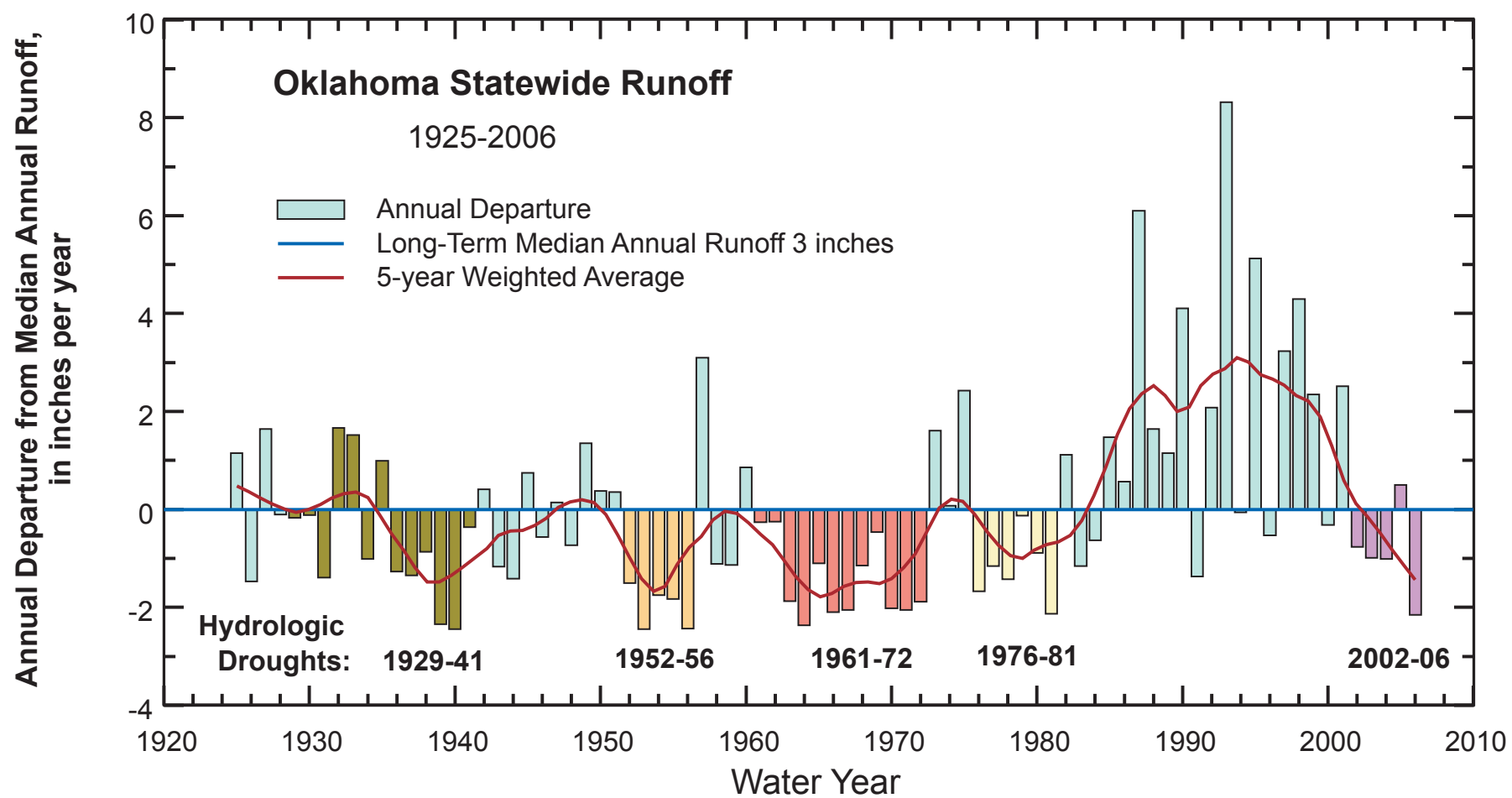

Figure 4. Oklahoma statewide runoff showing the annual departure from the long-term statewide median of 3 inches (blue line) and a 5-year weighted average line for water years 1925-2006 (red line). Wetter years plot above the median line and drier years plot below the median line. 
to the four previous major hydrologic drought periods by the 5-year weighted average line.

The hydrologic drought of water years 1929-41 was known as the "Dust Bowl" years in the Great Plains and is documented in several references (Hoyt, 1936 and 1938; Nace and Pluhowski, 1965; Egan, 2006; National Drought Mitigation Center, 2006b). This drought was particularly severe in western Oklahoma with a deficit runoff in 1934; whereas, major wind erosion happened over the entire state in 1936 (Nace and Pluhowski, 1965). The 1929-41 drought triggered nationwide soil conservation measures (National Drought Mitigation Center, 2006b).

The hydrologic drought of water years 1952-56 was the most widespread and the most severe for all regions of Oklahoma for precipitation and in most regions for runoff than the other hydrologic drought periods (Nace and Pluhowski, 1965; Tortorelli and others, 1991; figs. 3-4). This drought prompted the construction of Atoka Lake to provide a reliable water supply for Oklahoma City (Johnson, 1956) and prompted many Oklahoma communities to plan for long-term water supply.

The hydrologic drought of water years 1961-72 also was widespread and lasted longer than that in 1952-56 but generally was not as severe (Tortorelli and others, 1991; figs. 3-4). By this time many of the major reservoirs in Oklahoma were completed (Vance, 2007).

The hydrologic drought of water years 1976-81 also was widespread, but was not as severe or persistent as the previous three major droughts (Tortorelli and others, 1991; figs. 3-4).

The precipitation and runoff plots in figures 3 and 4 indicate that Water Year 2006 was very dry (second lowest statewide precipitation in the 1925-2006 study period) with very low statewide runoff (sixth lowest in the 1925-2006 study period). On that basis, drought conditions in Water Year 2006 were severe, but drought duration or persistence cannot yet be characterized (October 2006).

Regional streamflow patterns for Water Year 2006 (fig. 5) indicate that Oklahoma was part of the regionwide below-normal streamflow for the Arkansas-White-Red River Basin, the sixth driest since 1930 (U.S. Geological Survey, 2008a). Figure 6 shows the percentage of 82 long-term streamflow stations in Oklahoma (at least 30 years of record) having below normal streamflow during the water year 2002-2006 drought period (U.S. Geological Survey, 2008b). As indicated by the dashed line in figure 6 , about 25 percent of all stations can be expected to have streamflow below normal at any given time, where normal streamflow is considered to be within the $25^{\text {th }}$ and $75^{\text {th }}$ percentile at each site. Figure 6 shows that for some days in August and November 2006, the percentage of long-term stations having below-normal streamflow reached 80 to 85 percent.

\section{Acknowledgments}

The author thanks many people for their contributions to the data collection and data analysis presented in this report.
Deke Arndt of Oklahoma Climatological Survey supplied Water Year 2006 precipitation maps and Brian Vance of the Oklahoma Water Resources Board provided a modified Drought Sequence diagram from the National Drought Mitigation Center. Additional special thanks go to Daniel Fenner of the U.S. Fish and Wildlife Service for providing photographs of low flow in August 2006 at numerous sites along the reach of the Canadian River above Calvin. Rachel Esralew of the Oklahoma Water Science Center compiled site maps. USGS personnel provided low flow photographs in August 2006 at USGS streamflow gages. The Oklahoma Publishing Company provided the photograph of Thunderbird Lake shoreline on the back cover.

\section{Precipitation By Climate Division}

Oklahoma has nine National Weather Service Climate Divisions (fig. 7) for which monthly area-averaged precipitation data are available (National Climatic Data Center, 2007b). These data were totaled for each water year from 1925-2006. These totals give a sense of annual precipitation in Oklahoma on a regional basis.

Table 1 shows how Water Year 2006 precipitation compares with that during the driest year from each of the four previous major hydrologic droughts within each of the nine National Weather Service Climate Divisions to show how rainfall deficits in Oklahoma varied by region. Table 1 also shows how the annual precipitation for the selected years compares with the long-term median annual precipitation values for water years 1925-2006 ("normal") and the ranking (lowest ranking associated with driest year). Precipitation in water year 2006 was slightly less than the long-term climate division median in two of the nine climate divisions, Climate Division 1 Panhandle and Climate Division 4 West Central (minor rainfall deficits of 85 percent or more of normal precipitation). In all other climate divisions, Water Year 2006 precipitation was substantially less then the long-term climate division medians, with severe rainfall deficits ranging from only 65 to 73 percent of normal annual precipitation. Table 1 also shows that statewide precipitation Water Year 2006 was second driest in the 82 years of record from 1925-2006 and was only 72 percent of the normal precipitation. Only one year in the 1925-2006 period was drier, Water Year 1956 with only 56 percent of normal precipitation.

The Oklahoma Mesonet, a statewide network of environment monitoring stations, consists of 115 automated stations covering Oklahoma and provides 5-minute precipitation data. At least one station is located in each of 77 Oklahoma counties. Oklahoma Mesonet climate data are available since 1994, but were not used for this report so that data from one source (National Climatic Data Center, 2007b) for the period 1925-2006 would be used. In addition, Mesonet data uses mean annual precipitation from calendar years 1971-2000 as "normal" instead of median annual precipitation from 


\section{Regional Patterns}

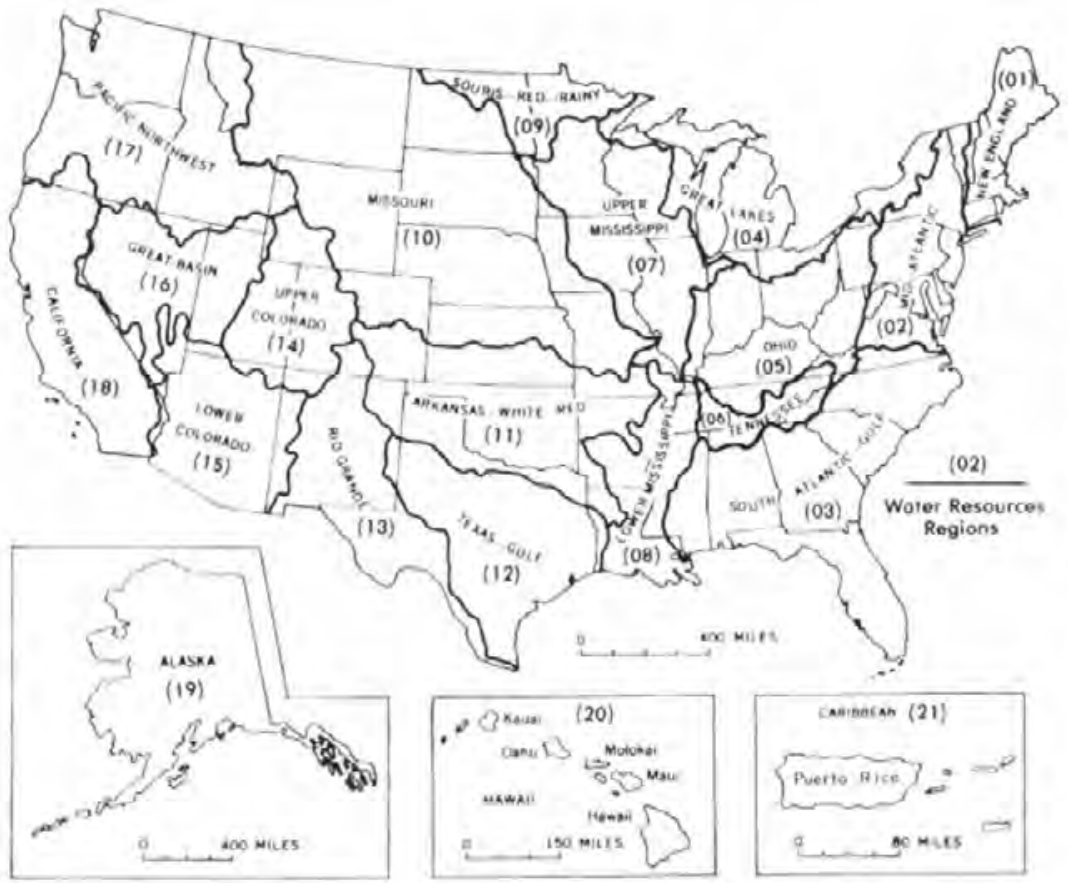

The United States (including Puerto Rico) is divided into 21 large drainages, or water resources regions. These hydrologic areas are based on surface topography and contain either the drainage area of a major river, such as the Columbia, the combined drainage areas of a series of rivers, such as the Texas-Gulf region which includes a number of rivers draining into the Gulf of Mexico, or the area of an island or island group. Water resources regions provide a coherent, watershed-based framework for depicting streamflow variations.

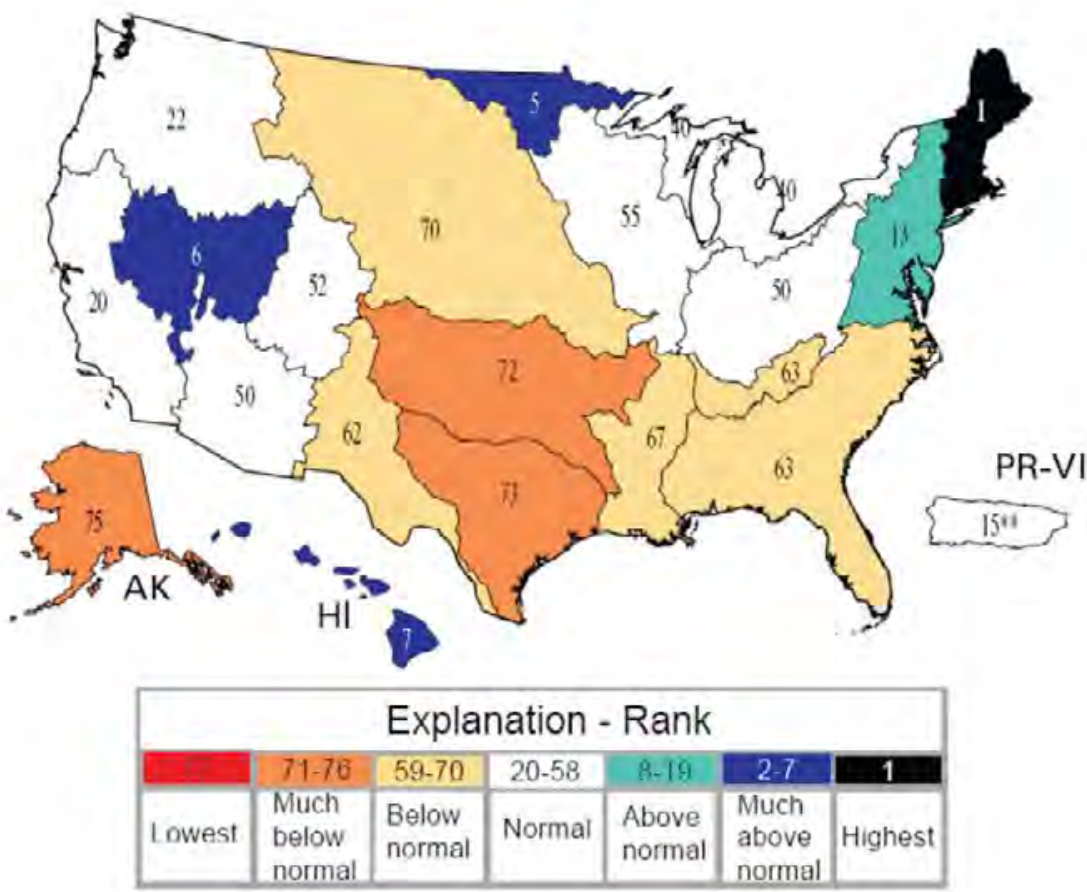

In 2006, notable regional streamflow differences were observed along the East Coast. The New England region, for example. recorded its highest annual flow since 1930 , reflecting the record high precipitation that fell on this area during the year. The SouthAtlantic Gulf region, in contrast, was below normal. Below-normal conditions also were prevalent for most the Great Plains regions and Alaska.

** Out of 63 years of historical data.

Figure 5. Regional streamflow patterns Water Year 2006 (U.S. Geological Survey, 2008a). 


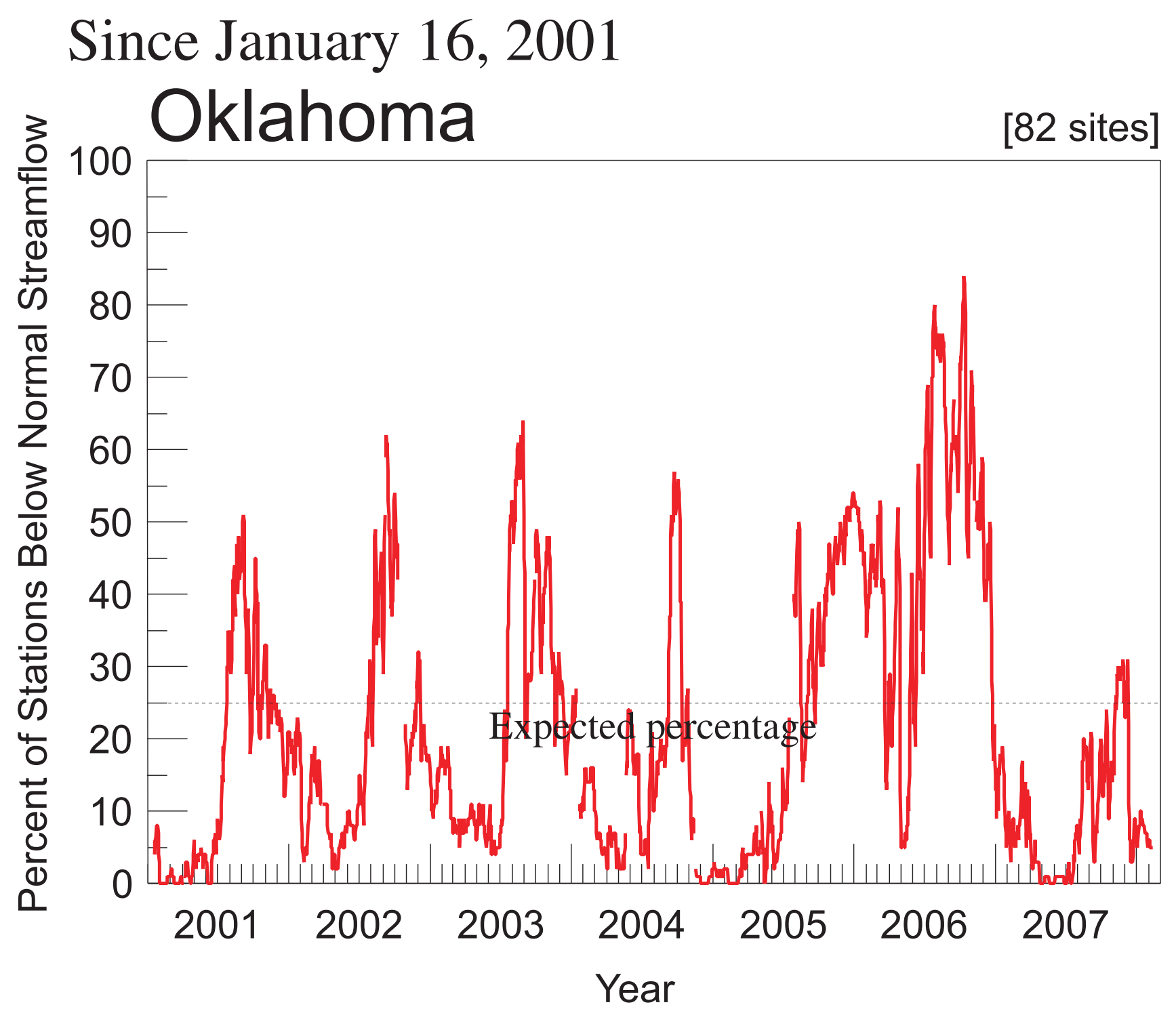

\section{EXPLANATION}

The Percent of Stations Below Normal Streamflow, plotted as the red line on the above graph, is calculated each day as the percent of streamflow gages having below normal flow, where the lower bound for normal is the 25th percentile value (dotted line) among all historical values for all days of the year. The percent of stations below normal is based only on streamflow gages in the state having at least 30 years of record

Figure 6. Percentage of stations below normal streamflow since January 16, 2001, through February 1, 2008, in Oklahoma (U.S. Geological Survey, 2007c). 
Table 1. Summary of precipitation at Climate Divisions in Oklahoma comparing the median of mean annual precipitation during water years 1925-2006 (measure of "normal" precipitation) with average annual precipitation during periods of previous documented hydrologic droughts and the recent hydrologic drought period.

[avg, average; \%, percent; Rank, rank of driest year of drought period out of period WY 1925-2006; WY, water year; SW, statewide]

\begin{tabular}{|c|c|c|c|c|c|c|}
\hline \multirow[b]{4}{*}{$\begin{array}{l}\text { Climate } \\
\text { Division } \\
\text { number }\end{array}$} & \multirow[b]{4}{*}{ Climate Division name } & \multirow[b]{4}{*}{$\begin{array}{l}\text { Long-term } \\
\text { annual } \\
\text { median } \\
\text { (inches) }\end{array}$} & \multicolumn{4}{|c|}{ Hydrologic Drought Periods } \\
\hline & & & \multirow{2}{*}{\multicolumn{2}{|c|}{$\begin{array}{c}\text { 1929-41 }^{3} \\
\text { Lowest year / Rank }\end{array}$}} & \multirow{2}{*}{\multicolumn{2}{|c|}{$\begin{array}{c}1952-56^{3} \\
\text { Lowest year / Rank }\end{array}$}} \\
\hline & & & & & & \\
\hline & & & $\begin{array}{c}\text { WY avg } \\
\text { annual } \\
\text { precipitation } \\
\text { (inches) }\end{array}$ & $\begin{array}{l}\text { Percent long- } \\
\text { term median }\end{array}$ & $\begin{array}{c}\text { WY Avg } \\
\text { annual } \\
\text { precipitation } \\
\text { (inches) }\end{array}$ & $\begin{array}{l}\text { Percent long- } \\
\text { term median }\end{array}$ \\
\hline \multirow[t]{2}{*}{ SW } & Statewide $^{1}$ & 33.51 & 1936 & 5 & 1956 & 1 \\
\hline & & & 25.24 & $75 \%$ & 18.68 & $56 \%$ \\
\hline \multirow[t]{2}{*}{1} & Panhandle ${ }^{2}$ & 19.54 & 1937 & 2 & 1956 & 1 \\
\hline & & & 12.24 & $63 \%$ & 11.34 & $58 \%$ \\
\hline \multirow[t]{2}{*}{2} & North Central $^{2}$ & 28.94 & 1936 & 6 & 1956 & 1 \\
\hline & & & 20.16 & $70 \%$ & 15.10 & $52 \%$ \\
\hline \multirow[t]{2}{*}{3} & Northeast $^{2}$ & 38.96 & 1939 & 8 & 1956 & 1 \\
\hline & & & 30.59 & $79 \%$ & 22.90 & $59 \%$ \\
\hline \multirow[t]{2}{*}{4} & West Central $^{2}$ & 26.55 & 1940 & 8 & 1952 & 1 \\
\hline & & & 20.14 & $76 \%$ & 15.98 & $60 \%$ \\
\hline \multirow[t]{2}{*}{5} & Central $^{2}$ & 33.73 & 1936 & 2 & 1956 & 1 \\
\hline & & & 24.03 & $71 \%$ & 19.74 & $59 \%$ \\
\hline \multirow[t]{2}{*}{6} & East Central $^{2}$ & 42.91 & 1936 & 3 & 1956 & 1 \\
\hline & & & 28.11 & $66 \%$ & 23.86 & $56 \%$ \\
\hline \multirow[t]{2}{*}{7} & Southwest ${ }^{2}$ & 27.56 & 1939 & 4 & 1956 & 1 \\
\hline & & & 18.75 & $68 \%$ & 17.45 & $63 \%$ \\
\hline \multirow[t]{2}{*}{8} & South Central ${ }^{2}$ & 36.63 & 1939 & 2 & 1956 & 1 \\
\hline & & & 24.19 & $66 \%$ & 16.46 & $45 \%$ \\
\hline \multirow[t]{2}{*}{9} & Southeast ${ }^{2}$ & 48.51 & 1934 & 2 & 1956 & 1 \\
\hline & & & 30.86 & $64 \%$ & 25.10 & $52 \%$ \\
\hline
\end{tabular}

\footnotetext{
${ }^{1}$ Ranks from Statewide Monthly Precipitation Totals, National Climatic Data Center (2007a)

2 Ranks from Climate Division Monthly Precipitation Totals, National Climatic Data Center (2007b).

${ }_{3}^{3}$ Documented drought periods are modified from Tortorelli and others, 1991.
} 
Table 1. Summary of precipitation at Climate Divisions in Oklahoma comparing the median of mean annual precipitation during water years 1925-2006 (measure of "normal" precipitation) with average annual precipitation during periods of previous documented hydrologic droughts and the recent hydrologic drought period.

[avg, average; \%, percent; Rank, rank of driest year of drought period out of period WY 1925-2006; WY, water year; SW, statewide]

\begin{tabular}{|c|c|c|c|c|c|c|c|c|}
\hline \multirow[b]{4}{*}{$\begin{array}{l}\text { Climate } \\
\text { Division } \\
\text { number }\end{array}$} & \multicolumn{8}{|c|}{ Hydrologic Drought Periods } \\
\hline & \multirow{2}{*}{\multicolumn{2}{|c|}{$\begin{array}{c}1_{1961-72}^{3} \\
\text { Lowest Year / Rank }\end{array}$}} & \multirow{2}{*}{\multicolumn{2}{|c|}{$\begin{array}{c}\text { 1976-1981 }{ }^{3} \\
\text { Lowest Year / Rank }\end{array}$}} & \multirow{2}{*}{\multicolumn{2}{|c|}{$\begin{array}{c}\text { 2002-2006 } \\
\text { Lowest Year / Rank }\end{array}$}} & \multirow{2}{*}{\multicolumn{2}{|c|}{2006}} \\
\hline & & & & & & & & \\
\hline & $\begin{array}{c}\text { WY avg } \\
\text { annual } \\
\text { precipitation } \\
\text { (inches) }\end{array}$ & $\begin{array}{l}\text { Percent } \\
\text { long-term } \\
\text { median }\end{array}$ & $\begin{array}{c}\text { WY avg } \\
\text { annual } \\
\text { precipitation } \\
\text { (inches) }\end{array}$ & $\begin{array}{l}\text { Percent } \\
\text { long-term } \\
\text { median }\end{array}$ & $\begin{array}{c}\text { WY avg } \\
\text { annual } \\
\text { precipitation } \\
\text { (inches) }\end{array}$ & $\begin{array}{l}\text { Percent } \\
\text { long-term } \\
\text { median }\end{array}$ & $\begin{array}{c}\text { WY avg } \\
\text { annual } \\
\text { precipitation } \\
\text { (inches) }\end{array}$ & $\begin{array}{l}\text { Percent } \\
\text { Iong-term } \\
\text { median }\end{array}$ \\
\hline \multirow[t]{2}{*}{ SW } & 1963 & 3 & 1978 & 10 & 2006 & 2 & & 2 \\
\hline & 24.60 & $73 \%$ & 27.11 & $81 \%$ & 24.12 & $72 \%$ & 24.12 & $72 \%$ \\
\hline \multirow[t]{2}{*}{1} & 1970 & 4 & 1976 & 29 & 2002 & 15 & & 22 \\
\hline & 13.05 & $67 \%$ & 17.58 & $90 \%$ & 15.34 & $79 \%$ & 16.69 & $85 \%$ \\
\hline \multirow[t]{2}{*}{2} & 1966 & 5 & 1976 & 14 & 2006 & 7 & & 7 \\
\hline & 20.15 & $70 \%$ & 23.24 & $80 \%$ & 20.23 & $70 \%$ & 20.23 & $70 \%$ \\
\hline \multirow[t]{2}{*}{3} & 1963 & 2 & 1981 & 14 & 2006 & 5 & & 5 \\
\hline & 24.81 & $64 \%$ & 32.89 & $84 \%$ & 28.29 & $73 \%$ & 28.29 & $73 \%$ \\
\hline \multirow[t]{2}{*}{4} & 1970 & 3 & 1976 & 24 & 2002 & 19 & & 28 \\
\hline & 18.00 & $68 \%$ & 22.23 & $84 \%$ & 21.90 & $82 \%$ & 23.46 & $88 \%$ \\
\hline \multirow[t]{2}{*}{5} & 1972 & 6 & 1976 & 7 & 2006 & 3 & & 3 \\
\hline & 25.08 & $74 \%$ & 25.41 & $75 \%$ & 24.17 & $72 \%$ & 24.17 & $72 \%$ \\
\hline \multirow[t]{2}{*}{6} & 1963 & 4 & 1980 & 6 & 2006 & 2 & & 2 \\
\hline & 28.24 & $66 \%$ & 30.30 & $71 \%$ & 27.70 & $65 \%$ & 27.70 & $65 \%$ \\
\hline \multirow[t]{2}{*}{7} & 1967 & 2 & 1980 & 23 & 2006 & 3 & & 3 \\
\hline & 17.46 & $63 \%$ & 23.40 & $85 \%$ & 18.59 & $67 \%$ & 18.59 & $67 \%$ \\
\hline \multirow[t]{2}{*}{8} & 1963 & 4 & 1978 & 8 & 2006 & 3 & & 3 \\
\hline & 25.15 & $69 \%$ & 27.78 & $76 \%$ & 24.45 & $67 \%$ & 24.45 & $67 \%$ \\
\hline \multirow[t]{2}{*}{9} & 1963 & 7 & 1978 & 3 & 2006 & 6 & & 6 \\
\hline & 35.02 & $72 \%$ & 31.95 & $66 \%$ & 34.89 & $72 \%$ & 34.89 & $72 \%$ \\
\hline
\end{tabular}




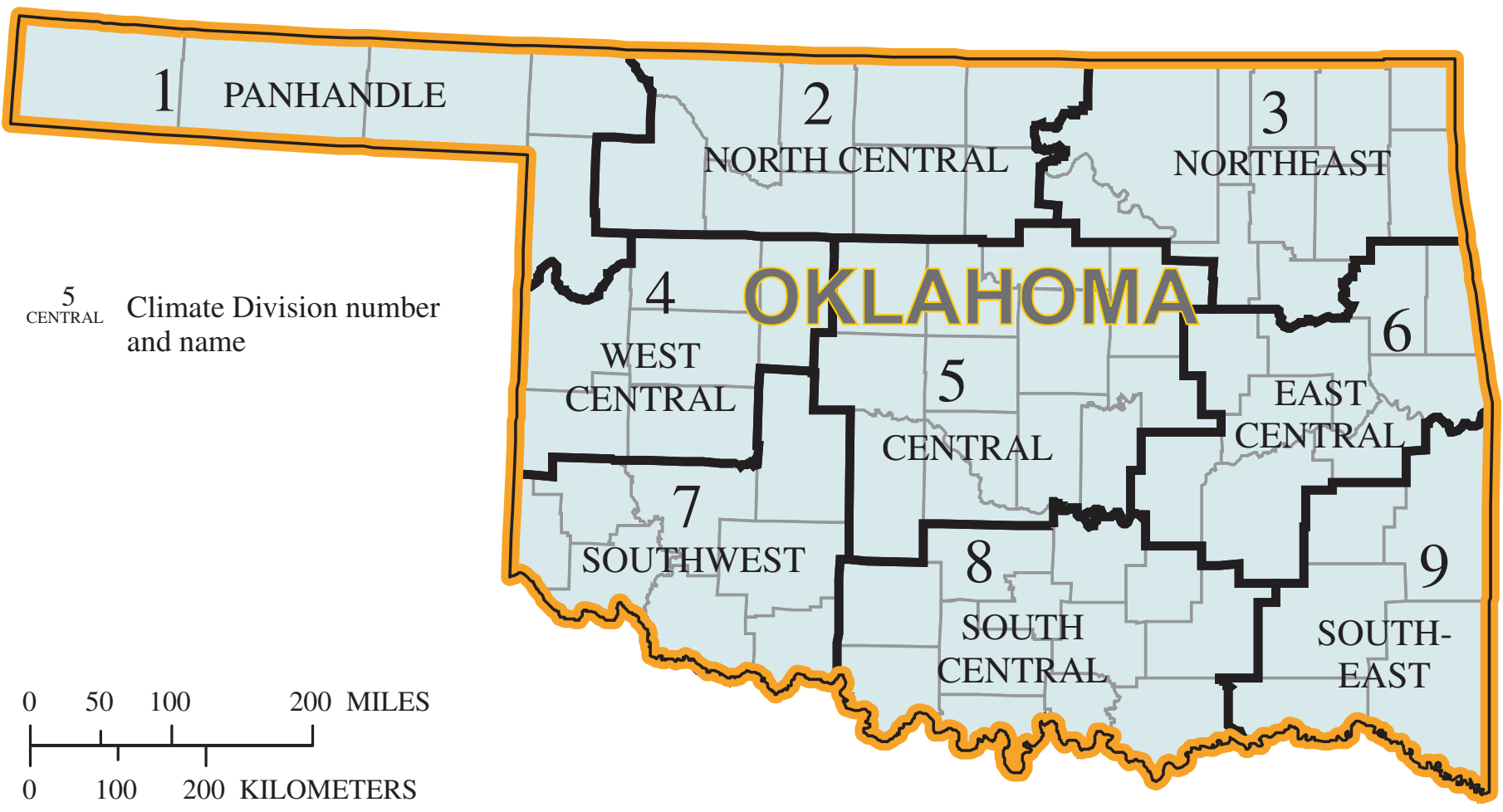

Albers Equal Area Conic Projection

Figure 7. National Weather Service Climate Divisions in Oklahoma.

water years 1925-2006. This period contains an extremely wet period (fig. 3); therefore, data presented on the Mesonet website (fig. 8; Oklahoma Climatological Survey, 2008a, 2008 b) indicated more severe precipitation deficits in 2006 than in table 1. However, these data do show how Water Year 2006 differs from normal and give a sense of regional rainfall deficits.

\section{Climate Division 1 Panhandle}

Climate Division 1 Panhandle is in far northwest Oklahoma. Water Year 2006 was the $22^{\text {nd }}$ driest in the 82 years of record from 1925-2006, with 16.69 inches of rainfall, a deficit of 2.85 inches or 85 percent of normal area precipitation (table 1). Water Year 1956 was the driest year, from the 1952-56 drought period, with only 11.34 inches of rainfall, a deficit of 8.20 inches or 58 percent of normal annual area precipitation.

\section{Climate Division 2 North Central}

Climate Division 2 North Central is in north-central Oklahoma. Water Year 2006 was the seventh driest in the 82 years of record from 1925-2006, with 20.23 inches of rainfall, a deficit of 8.71 inches or 70 percent of normal area precipitation (table 1). Water Year 1956 was the driest year, from the 1952-56 drought period, with only 15.10 inches of rainfall, a deficit of 13.84 inches or 52 percent of normal annual area precipitation.

\section{Climate Division 3 Northeast}

Climate Division 3 Northeast is in northeast Oklahoma. Water Year 2006 was the fifth driest in the 82 years of record from 1925-2006, with 28.29 inches of rainfall, a deficit of 10.67 inches or 73 percent of normal area precipitation (table 1). Water Year 1956 was the driest year, from the 1952-56 drought period, with only 22.90 inches of rainfall, a deficit of 16.06 inches or 59 percent of normal annual area precipitation.

\section{Climate Division 4 West Central}

Climate Division 4 West Central is in west-central Oklahoma. Water Year 2006 was the $28^{\text {th }}$ driest in the 82 years of record from 1925-2006, with 23.46 inches of rainfall, a deficit of 3.09 inches or 88 percent of normal area precipitation (table 1). Water Year 1952 was the driest year, from the 1952-56 drought period, with only 15.98 inches of rainfall, a deficit of 10.57 inches or 60 percent of normal annual area precipitation. 

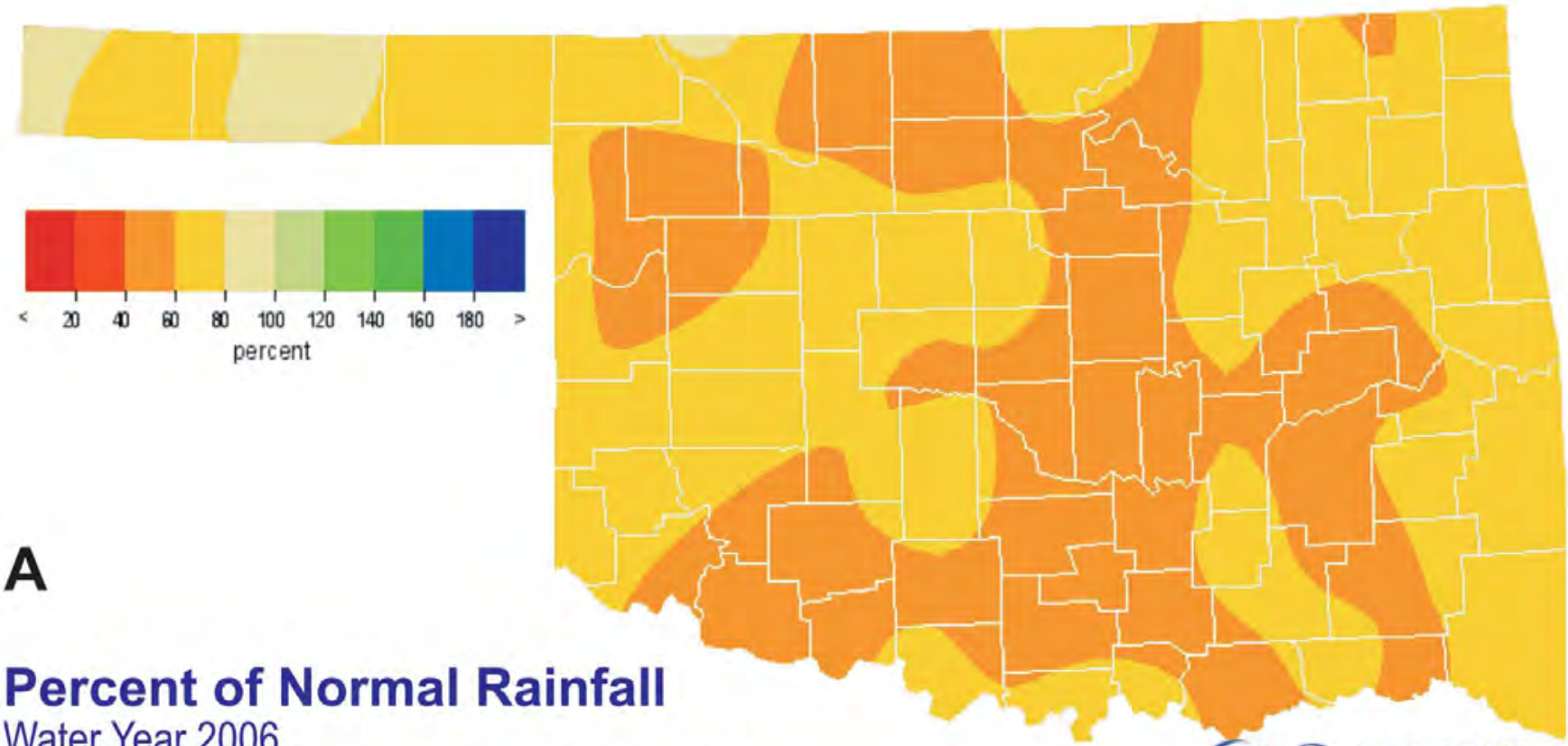

Percent of Normal Rainfall

Water Year 2006

October 1, 2005, through September 30, 2006

copyright (c)2006 Oklahoma Clin atological Survey. All rights reserved. Raintall data collected by Oklahoma Mesonet

C) OKLAHOMA Image created 15:27 CST Dec 18,2006

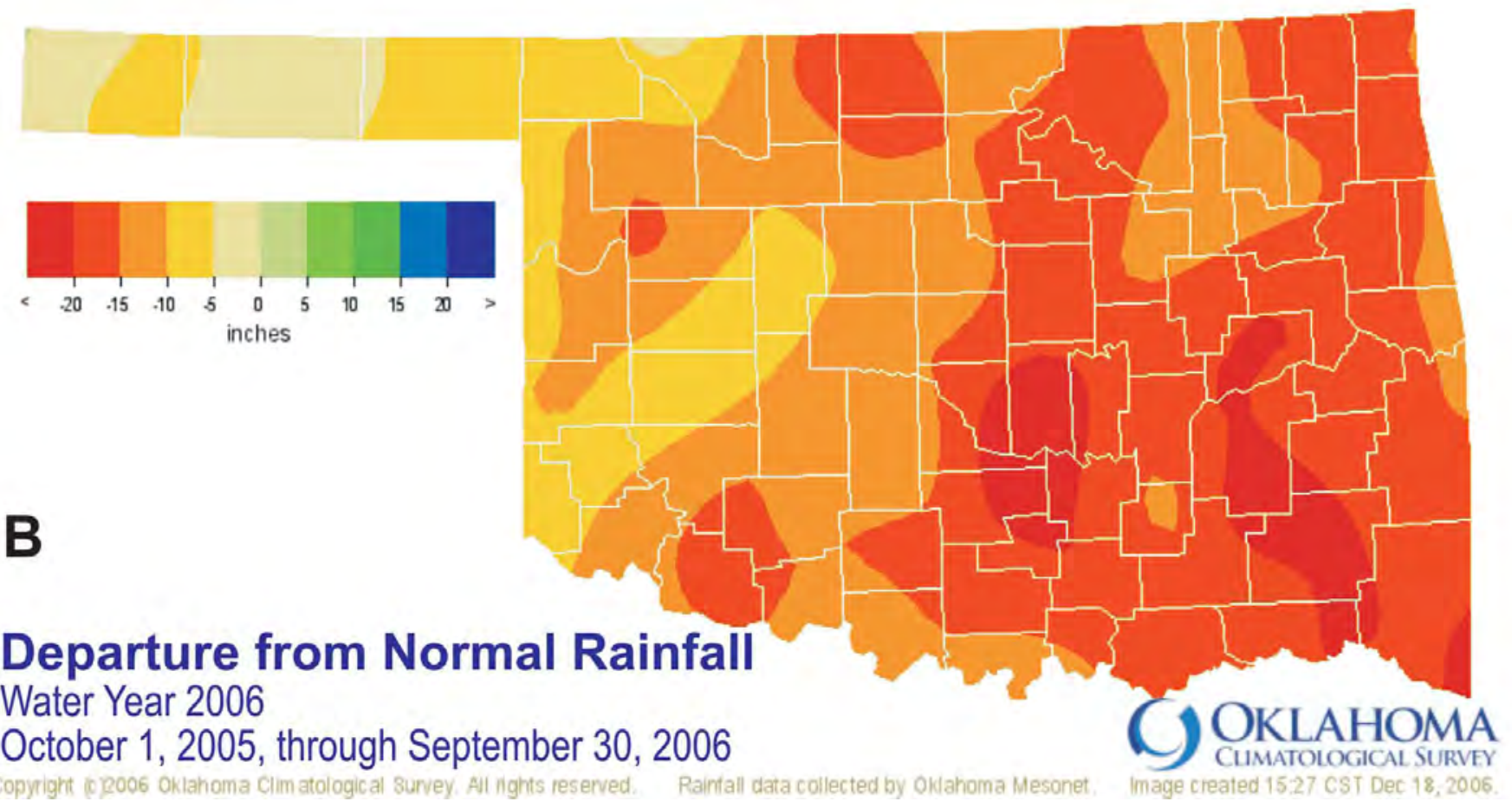

Figure 8. Oklahoma $(A)$ percent of normal rainfall, Water Year 2006 (Oklahoma Climatological Survey, 2008a) $(B)$ departure from normal rainfall, Water Year 2006 (Oklahoma Climatological Survey, 2008b). 


\section{Climate Division 5 Central}

Climate Division 5 Central is in central Oklahoma. Water Year 2006 was the third driest in the 82 years of record from 1925-2006, with 24.17 inches of rainfall, a deficit of 9.56 inches or 72 percent of normal area precipitation (table 1). Water Year 1956 was the driest year, from the 1952-56 drought period, with only 19.74 inches of rainfall, a deficit of 13.99 inches or 59 percent of normal annual area precipitation.

\section{Climate Division 6 East Central}

Climate Division 6 East Central is in east-central Oklahoma. Water Year 2006 was the second driest in the 82 years of record from 1925-2006, with 27.70 inches of rainfall, a deficit of 15.21 inches or 65 percent of normal area precipitation (table 1). Water Year 1956 was the driest year, from the 1952-56 drought period, with only 23.86 inches of rainfall, a deficit of 19.05 inches or 56 percent of normal annual area precipitation.

\section{Climate Division 7 Southwest}

Climate Division 7 Southwest is in southwest Oklahoma. Water Year 2006 was the third driest in the 82 years of record from 1925-2006, with 18.59 inches of rainfall, a deficit of 8.97 inches or 67 percent of normal area precipitation (table 1). Water Year 1956 was the driest year, from the 1952-56 drought period, with only 17.45 inches of rainfall, a deficit of 10.11 inches or 63 percent of normal annual area precipitation.

\section{Climate Division 8 South Central}

Climate Division 8 South Central is in south-central Oklahoma. Water Year 2006 was the third driest in the 82 years of record from 1925-2006, with 24.45 inches of rainfall, a deficit of 12.18 inches or 67 percent of normal area precipitation (table 1). Water Year 1956 was the driest year, from the 1952-56 drought period, with only 16.46 inches of rainfall, a deficit of 20.17 inches or 45 percent of normal annual area precipitation.

\section{Climate Division 9 Southeast}

Climate Division 9 Southeast is in southeast Oklahoma. Water Year 2006 was the sixth driest in the 82 years of record from 1925-2006, with 34.89 inches of rainfall, a deficit of 13.62 inches or 72 percent of normal area precipitation (table 1). Water Year 1956 was the driest year, from the 1952-56 drought period, with only 25.10 inches of rainfall, a deficit of 23.41 inches or 52 percent of normal annual area precipitation.

\section{Streamflow of Long-Term Sites}

Twelve long-term streamflow-gaging sites with periods of record ranging from 62 to 78 years were selected to show how streamflow deficits varied by region (fig. 9, table 2). Two graphs are presented for each long-term site (figs. 10 to 21). The first graph is similar to the statewide runoff plot in figure 4. The annual mean streamflow (U.S. Geological Survey, 2007b) for each water year of the period of record is plotted as a departure bar from the long-term median annual flow ("normal" annual flow, blue line), and a 5-year weighted-average departure streamflow is plotted as a red line (A graphs). Wetter years plot above the median line and drier years plot below the median line. Water Year 2006 then can be compared to the dry years from the four previous major hydrologic droughts in the 20th century by the depth of bars. The length and severity of the water year 2002-2006 drought period in terms of streamflow deficit can be compared to the four previous major hydrologic droughts by the 5-year weighted average line.

The second graph shows a comparison of the daily-mean flow from Water Year 2006 (red line; U.S. Geological Survey, 2008d) to the long-term daily mean flow (blue line; U.S. Geological Survey, 2008e) and provides an indication of how the streamflow deficits changed seasonally (B graphs).

Table 2 shows how Water Year 2006 streamflow from each long-term site compares with the driest year from each of the four previous major hydrologic droughts in the 20th century, and shows the rank and percent of long-term medianannual flow ("normal") for each low-flow year. Statewide runoff during the driest years also is ranked. Statewide runoff in Water Year 2006 was sixth driest in the 82 years of record from 1925-2006.

\section{Salt Fork Arkansas River at Tonkawa}

Salt Fork Arkansas River at Tonkawa (07151000) is a streamflow-gaging site in north-central Oklahoma. Water Year 2006 was the sixth driest in the 65 years of record from 1942-2006, with just 19 percent of normal annual flow (table 2). Water Year 1954 was the driest year, from the 1952-56 drought period, with 12 percent of normal annual flow. Zero flow was not recorded during Water Year 2006, with some wet periods in November, May, and June (fig. 10). The lowest flow was at the end of the water year in August and September (fig. 10; appendix 1; U.S. Geological Survey, 2008c).

\section{Chikaskia River near Blackwell}

Chikaskia River near Blackwell (07152000) is a streamflow-gaging site in north-central Oklahoma. Water Year 2006 was the $15^{\text {th }}$ driest in the 70 years of record from 1937-2006, with 45 percent of normal annual flow (table 2). Water Year 1954 was the driest year, from the 1952-56 drought period, 


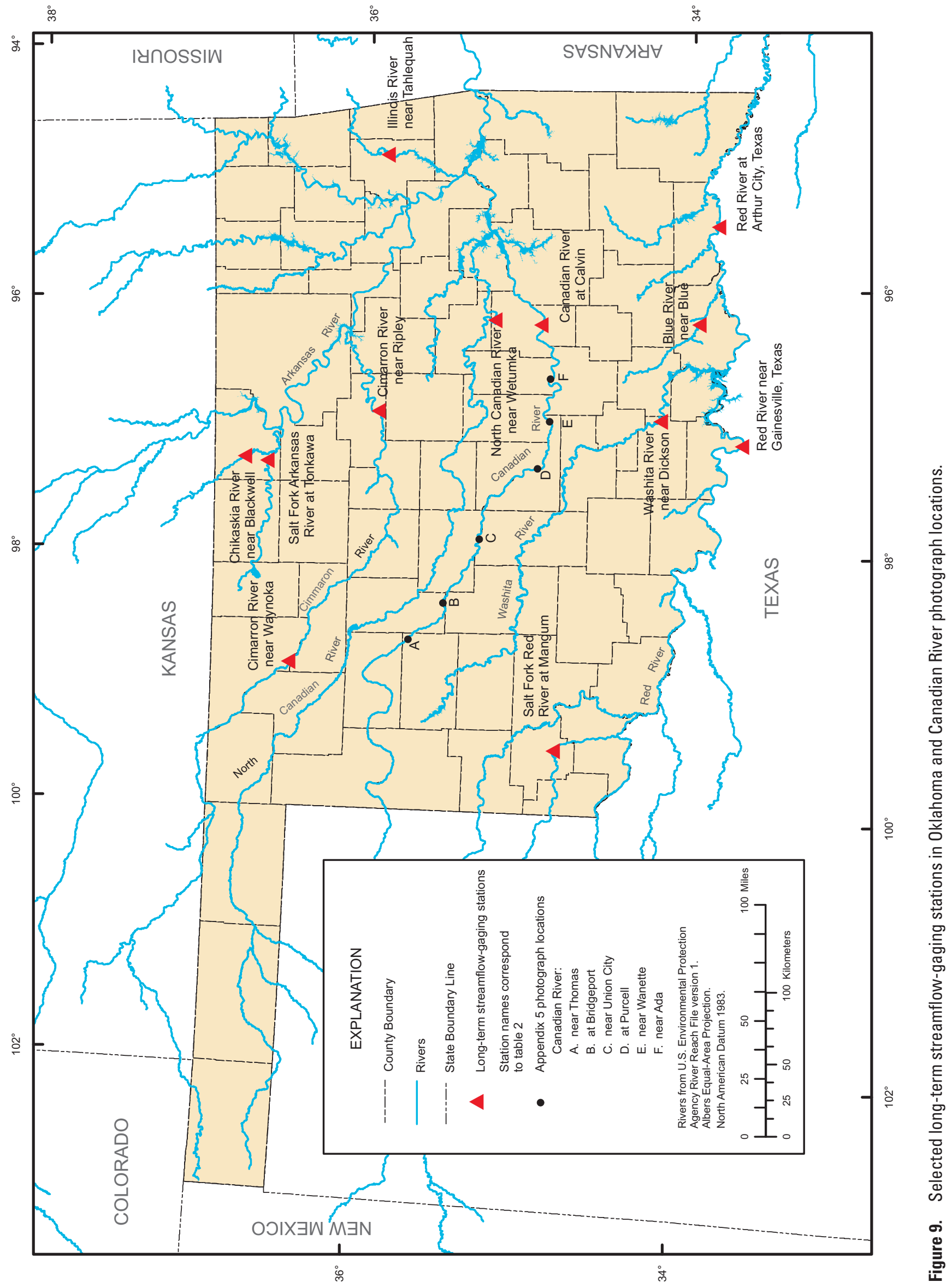


Table 2. Summary of streamflow conditions at selected long-term streamflow-gaging stations in Oklahoma comparing the median of mean annual streamflow (measure of "normal" streamflow) with average annual streamflow during periods of previous documented hydrologic droughts and the recent hydrologic drought period.

[yr, year; avg, average; Rank, rank of driest year of drought period out of period of record; mi², square miles; N, nonregulated; R, regulated; WY, water year; $\mathrm{ft}^{3} / \mathrm{s}$, cubic feet per second; SW, statewide]

\begin{tabular}{|c|c|c|c|c|c|c|c|}
\hline $\begin{array}{l}\text { Site } \\
\text { no. }\end{array}$ & $\begin{array}{l}\text { Station } \\
\text { number }\end{array}$ & Station name & $\begin{array}{c}\text { Contributing } \\
\text { drainage } \\
\text { area } \\
\left(\mathrm{mi}^{2}\right)\end{array}$ & $\begin{array}{l}\text { Type of } \\
\text { record } \\
\text { (N/R) }\end{array}$ & $\begin{array}{l}\text { Continuous record } \\
\text { period of record } \\
\text { (complete WY) }\end{array}$ & $\begin{array}{l}\text { Years } \\
\text { of } \\
\text { record }\end{array}$ & $\begin{array}{c}\text { Long-term } \\
\text { annual } \\
\text { median } \\
\left(\mathrm{ft}^{3} / \mathrm{s}\right)\end{array}$ \\
\hline
\end{tabular}

\begin{tabular}{|c|c|c|c|c|c|c|c|}
\hline SW & & Statewide $^{1}$ & & & $1925-2006^{1}$ & 82 & \\
\hline 1 & 07151000 & Salt Fork Arkansas River at Tonkawa, Okla. & 4,520 & $\mathrm{R}$ & $1942-2006$ & 65 & 808 \\
\hline 2 & 07152000 & Chikaskia River near Blackwell, Okla. & 1,859 & $\mathrm{~N}$ & $1937-2006$ & 70 & 480 \\
\hline 4 & 07161450 & Cimarron River near Ripley, Okla. ${ }^{2}$ & 13,053 & $\mathrm{~N}$ & $1940-2006$ & 67 & 1,345 \\
\hline
\end{tabular}

\begin{tabular}{cclcccc}
5 & 07196500 & Illinois River near Tahlequah, Okla. & 959 & N & $1936-2006$ & 71 \\
\hline 6 & 07231500 & Canadian River at Calvin, Okla. & 23,151 & N,R & $1939-42,1945-2006$ & 66
\end{tabular}

\begin{tabular}{cccccccc}
7 & 07242000 & North Canadian River near Wetumka, Okla. & 9,391 & R & $1938-2006$ & 693 \\
\hline 8 & 07300500 & Salt Fork Red River at Mangum, Okla. & 1,357 & N & $1938-2006$ & 69
\end{tabular}

\begin{tabular}{ccccccc}
9 & 07316000 & Red River near Gainesville, Texas & 24,846 & N,R & $1937-2006$ & 70 \\
\hline 10 & 07331000 & Washita River near Dickson, Okla. & 7,202 & N,R & $1929-2006$ & 78 \\
\hline
\end{tabular}

\begin{tabular}{lllllll}
11 & 07332500 & Blue River near Blue, Okla. & 476 & N & $1937-2006$ & 70 \\
12 & 07335500 & Red River at Arthur City, Texas & 38,595 & R & $1945-2006$ & 62 \\
\hline
\end{tabular}

\footnotetext{
${ }^{1}$ Ranks from Statewide Annual Runoff Summary USGS Waterwatch web page, U.S. Geological Survey (2007a) Although there is record from continuous streamflow gages since WY 1903, there were few operating gages and gaps where no gages were operating prior to 1925.

${ }^{2}$ Includes streamflow record 1940-87 from nearby station 07161000, Cimarron River at Perkins, Okla.

${ }^{3}$ Documented drought periods are modified from Tortorelli and others, 1991.

${ }^{4}$ Station records do not span entire drought period
} 
Table 2. Summary of streamflow conditions at selected long-term streamflow-gaging stations in Oklahoma comparing the median of mean annual streamflow (measure of "normal" streamflow) with average annual streamflow during periods of previous documented hydrologic droughts and the recent hydrologic drought period. - Continued

[yr, year; avg, average; Rank, rank of driest year of drought period out of period of record; mi², square miles; N, nonregulated; R, regulated; WY, water year; $\mathrm{ft}^{3} / \mathrm{s}$, cubic feet per second; SW, statewide]

\begin{tabular}{|c|c|c|c|c|c|c|c|c|c|c|c|c|}
\hline \multirow[b]{4}{*}{$\begin{array}{l}\text { Site } \\
\text { no. }\end{array}$} & \multicolumn{12}{|c|}{ Hydrologic Drought Periods } \\
\hline & \multirow{2}{*}{\multicolumn{2}{|c|}{$\begin{array}{c}1929-41^{3} \\
\text { Lowest yr / Rank }\end{array}$}} & \multirow{2}{*}{\multicolumn{2}{|c|}{$\begin{array}{c}1952-56^{3} \\
\text { Lowest yr / Rank }\end{array}$}} & \multirow{2}{*}{\multicolumn{2}{|c|}{$\begin{array}{c}1961-72^{3} \\
\text { Lowest yr / Rank }\end{array}$}} & \multirow{2}{*}{\multicolumn{2}{|c|}{$\begin{array}{c}1976-1981^{3} \\
\text { Lowest yr / Rank }\end{array}$}} & \multirow{2}{*}{\multicolumn{2}{|c|}{$\begin{array}{c}\text { 2002-2006 } \\
\text { Lowest yr / Rank }\end{array}$}} & \multirow{2}{*}{\multicolumn{2}{|c|}{2006}} \\
\hline & & & & & & & & & & & & \\
\hline & $\begin{array}{c}\text { Avg } \\
\text { annual } \\
\text { flow } \\
\left(\mathrm{ft}^{3} / \mathrm{s}\right)\end{array}$ & $\begin{array}{l}\text { Percent } \\
\text { long- } \\
\text { term } \\
\text { median }\end{array}$ & $\begin{array}{c}\text { Avg } \\
\text { annual } \\
\text { flow } \\
\left(\mathrm{ft}^{3} / \mathrm{s}\right)\end{array}$ & $\begin{array}{c}\text { Percent } \\
\text { long- } \\
\text { term } \\
\text { median }\end{array}$ & $\begin{array}{c}\text { Avg } \\
\text { annual } \\
\text { flow } \\
\left(\mathrm{ft}^{3} / \mathrm{s}\right)\end{array}$ & $\begin{array}{l}\text { Percent } \\
\text { Iong- } \\
\text { term } \\
\text { median }\end{array}$ & $\begin{array}{c}\text { Avg } \\
\text { annual } \\
\text { flow } \\
\left(\mathrm{ft}^{3} / \mathrm{s}\right)\end{array}$ & $\begin{array}{l}\text { Percent } \\
\text { long- } \\
\text { term } \\
\text { median }\end{array}$ & $\begin{array}{c}\text { Avg } \\
\text { annual } \\
\text { flow } \\
\left(\mathrm{ft}^{3} / \mathrm{s}\right)\end{array}$ & $\begin{array}{l}\text { Percent } \\
\text { long- } \\
\text { term } \\
\text { median }\end{array}$ & $\begin{array}{c}\text { Avg } \\
\text { annual } \\
\text { flow } \\
\left(\mathrm{ft}^{3} / \mathbf{s}\right)\end{array}$ & $\begin{array}{c}\text { Percent } \\
\text { long- } \\
\text { term } \\
\text { median }\end{array}$ \\
\hline SW & 1940 & 1 & 1953 & 2 & 1964 & 4 & 1981 & 7 & 2006 & 6 & & 6 \\
\hline \multirow[t]{2}{*}{1} & NA & & 1954 & 1 & 1964 & 3 & 1981 & 13 & 2006 & 6 & & 6 \\
\hline & & & 95.5 & $12 \%$ & 137 & $17 \%$ & 280 & $35 \%$ & 157 & $19 \%$ & 157 & $19 \%$ \\
\hline \multirow[t]{2}{*}{2} & $1940^{4}$ & 2 & 1954 & 1 & 1966 & 4 & 1981 & 7 & 2006 & 15 & & 15 \\
\hline & 76.6 & $16 \%$ & 71.0 & $15 \%$ & 97.6 & $20 \%$ & 152 & $32 \%$ & 217 & $45 \%$ & 217 & $45 \%$ \\
\hline \multirow[t]{2}{*}{3} & $1939^{4}$ & 26 & 1956 & 5 & 1971 & 4 & 1977 & 17 & 2002 & 3 & & 10 \\
\hline & 174 & $75 \%$ & 53.6 & $23 \%$ & 46.7 & $20 \%$ & 134 & $58 \%$ & 46.0 & $20 \%$ & 96.1 & $42 \%$ \\
\hline \multirow[t]{2}{*}{4} & $1940^{4}$ & 4 & 1953 & 1 & 1971 & 2 & 1981 & 11 & 2006 & 12 & & 12 \\
\hline & 307 & $23 \%$ & 235 & $17 \%$ & 294 & $22 \%$ & 455 & $34 \%$ & 491 & $37 \%$ & 491 & $37 \%$ \\
\hline \multirow[t]{2}{*}{5} & $1940^{4}$ & 6 & 1954 & 1 & 1964 & 3 & 1981 & 5 & 2006 & 8 & & 8 \\
\hline & 279 & $30 \%$ & 193 & $21 \%$ & 239 & $26 \%$ & 275 & $30 \%$ & 289 & $31 \%$ & 289 & $31 \%$ \\
\hline \multirow[t]{2}{*}{6} & $1940^{4}$ & 8 & 1956 & 6 & 1966 & 3 & 1981 & 1 & 2006 & 2 & & 2 \\
\hline & 478 & $35 \%$ & 393 & $29 \%$ & 217 & $16 \%$ & 184 & $13 \%$ & 190 & $14 \%$ & 190 & $14 \%$ \\
\hline \multirow[t]{2}{*}{7} & $1940^{4}$ & 2 & 1956 & 1 & 1963 & 3 & 1981 & 5 & 2006 & 4 & & 4 \\
\hline & 157 & $23 \%$ & 156 & $23 \%$ & 166 & $24 \%$ & 178 & $26 \%$ & 176 & $26 \%$ & 176 & $26 \%$ \\
\hline \multirow[t]{2}{*}{8} & $1940^{4}$ & 1 & 1952 & 4 & 1971 & 2 & 1981 & 5 & 2006 & 3 & & 3 \\
\hline & 12.3 & $17 \%$ & 17.5 & $24 \%$ & 12.5 & $17 \%$ & 22.7 & $32 \%$ & 14.4 & $20 \%$ & 14.4 & $20 \%$ \\
\hline \multirow[t]{2}{*}{9} & $1939^{4}$ & 5 & 1953 & 2 & 1964 & 3 & 1983 & 12 & 2006 & 1 & & 1 \\
\hline & 1,010 & $40 \%$ & 651 & $26 \%$ & 654 & $26 \%$ & 1,274 & $50 \%$ & 567 & $22 \%$ & 567 & $22 \%$ \\
\hline \multirow[t]{2}{*}{10} & $1939^{4}$ & 3 & 1956 & 5 & 1964 & 1 & 1981 & 7 & 2006 & 2 & & 2 \\
\hline & 391 & $28 \%$ & 441 & $31 \%$ & 340 & $24 \%$ & 495 & $35 \%$ & 384 & $27 \%$ & 384 & $27 \%$ \\
\hline \multirow[t]{2}{*}{11} & $1939^{4}$ & 2 & 1956 & 1 & 1964 & 9 & 1980 & 4 & 2006 & 5 & & 5 \\
\hline & 42.9 & $17 \%$ & 30.8 & $12 \%$ & 114 & $45 \%$ & 77.7 & $31 \%$ & 79.5 & $31 \%$ & 79.5 & $31 \%$ \\
\hline \multirow[t]{2}{*}{12} & NA & & 1952 & 9 & 1964 & 2 & 1980 & 3 & 2006 & 1 & & 1 \\
\hline & & & 4,182 & $58 \%$ & 2,754 & $38 \%$ & 2,953 & $41 \%$ & 1,794 & $25 \%$ & 1,794 & $25 \%$ \\
\hline
\end{tabular}



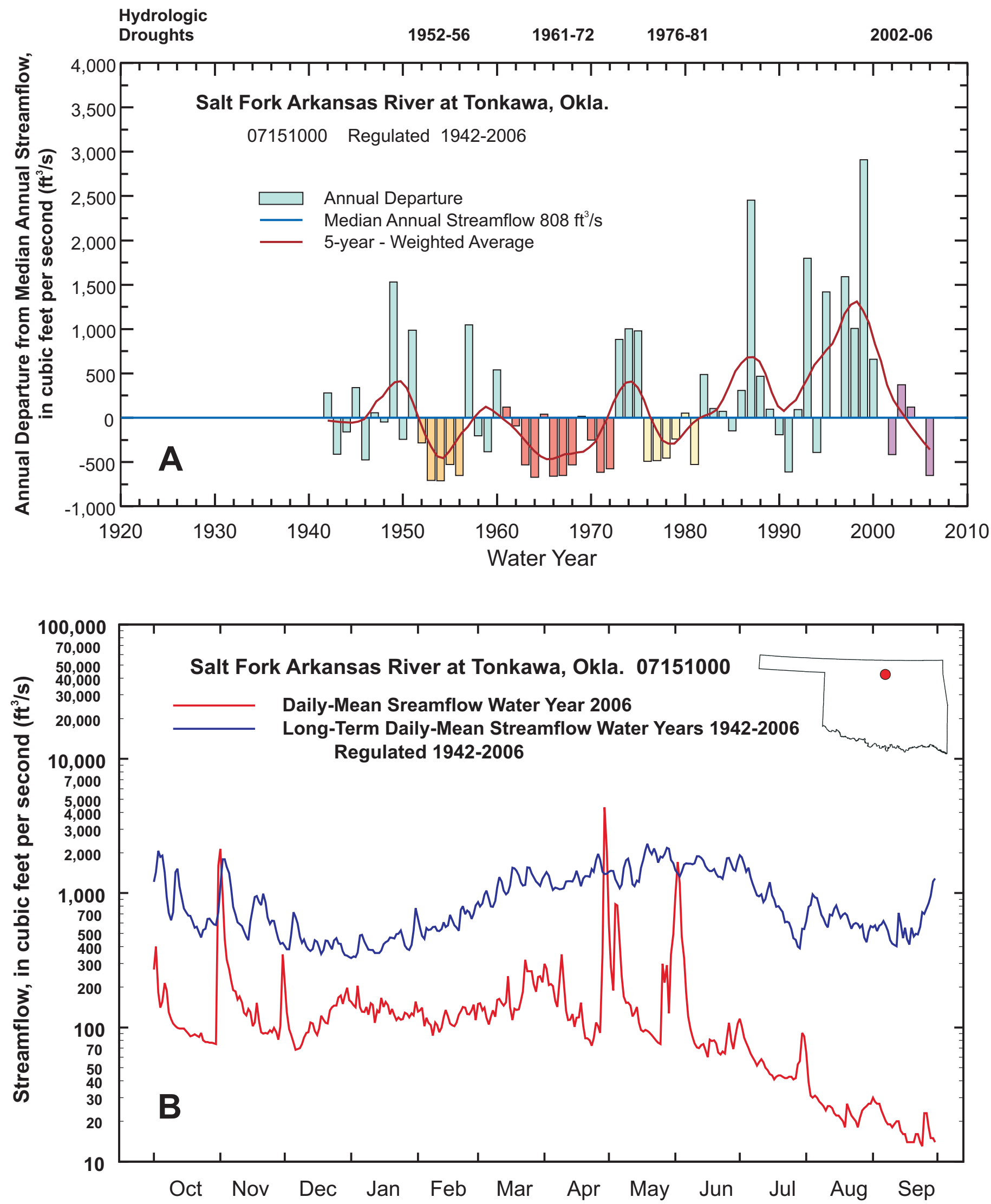

Figure 10. Salt Fork Arkansas River at Tonkawa $(A)$ annual departure from long-term median annual streamflow, water years 1942-2006 (B) comparing daily-mean streamflow of Water Year 2006 and long-term daily-mean streamflow, water years 1942-2006. 

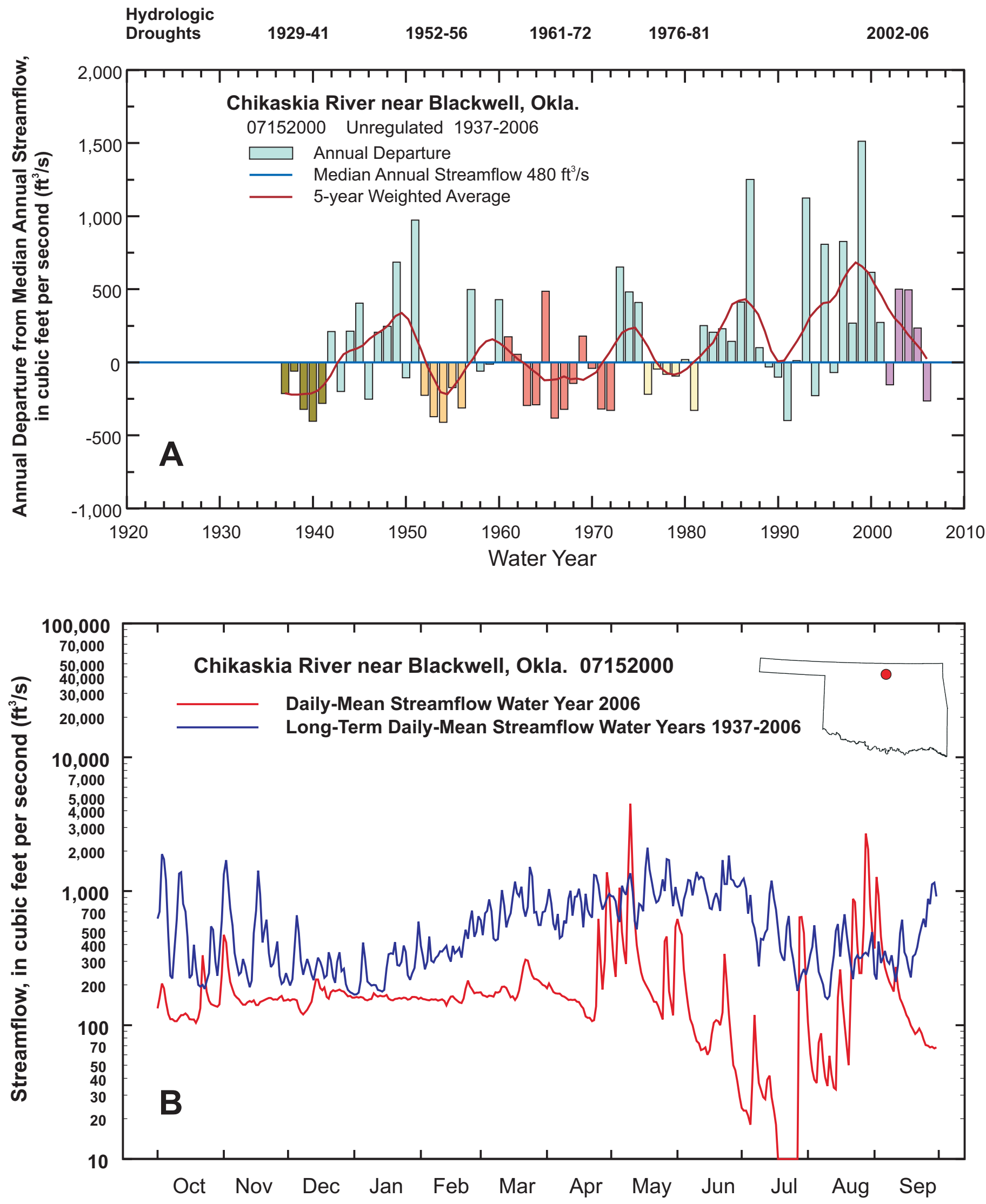

Figure 11. Chikaskia River near Blackwell ( $A$ ) annual departure from long-term median annual streamflow, water years 1937-2006 $(B)$ comparing daily-mean streamflow of Water Year 2006 and long-term daily-mean streamflow, water years 1937-2006. 

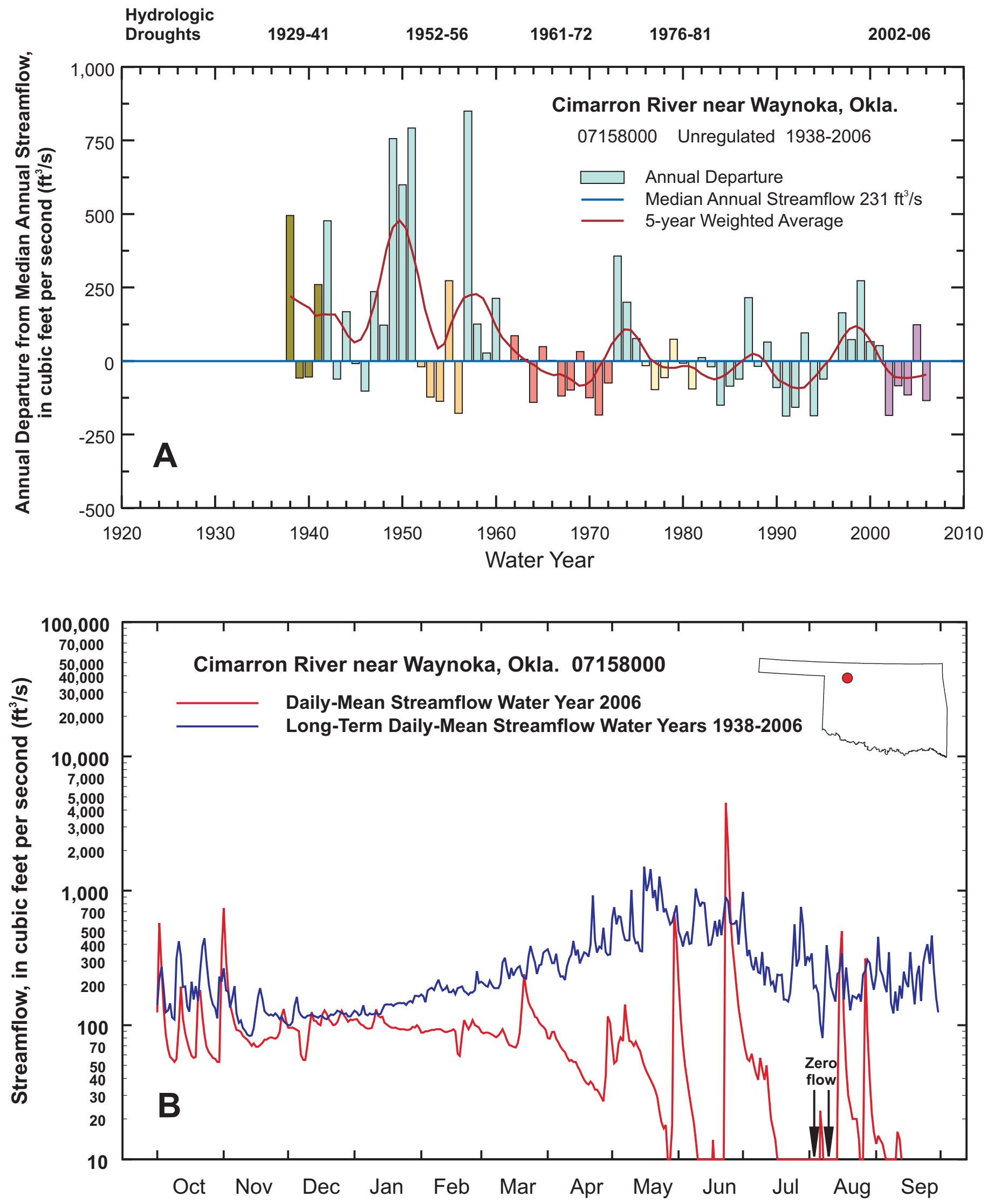

Figure 12. Cimarron River near Waynoka $(A)$ annual departure from long-term median annual streamflow, water years 1938-2006 (B) comparing daily-mean streamflow of Water Year 2006 and long-term daily-mean streamflow, water years 1938-2006. 

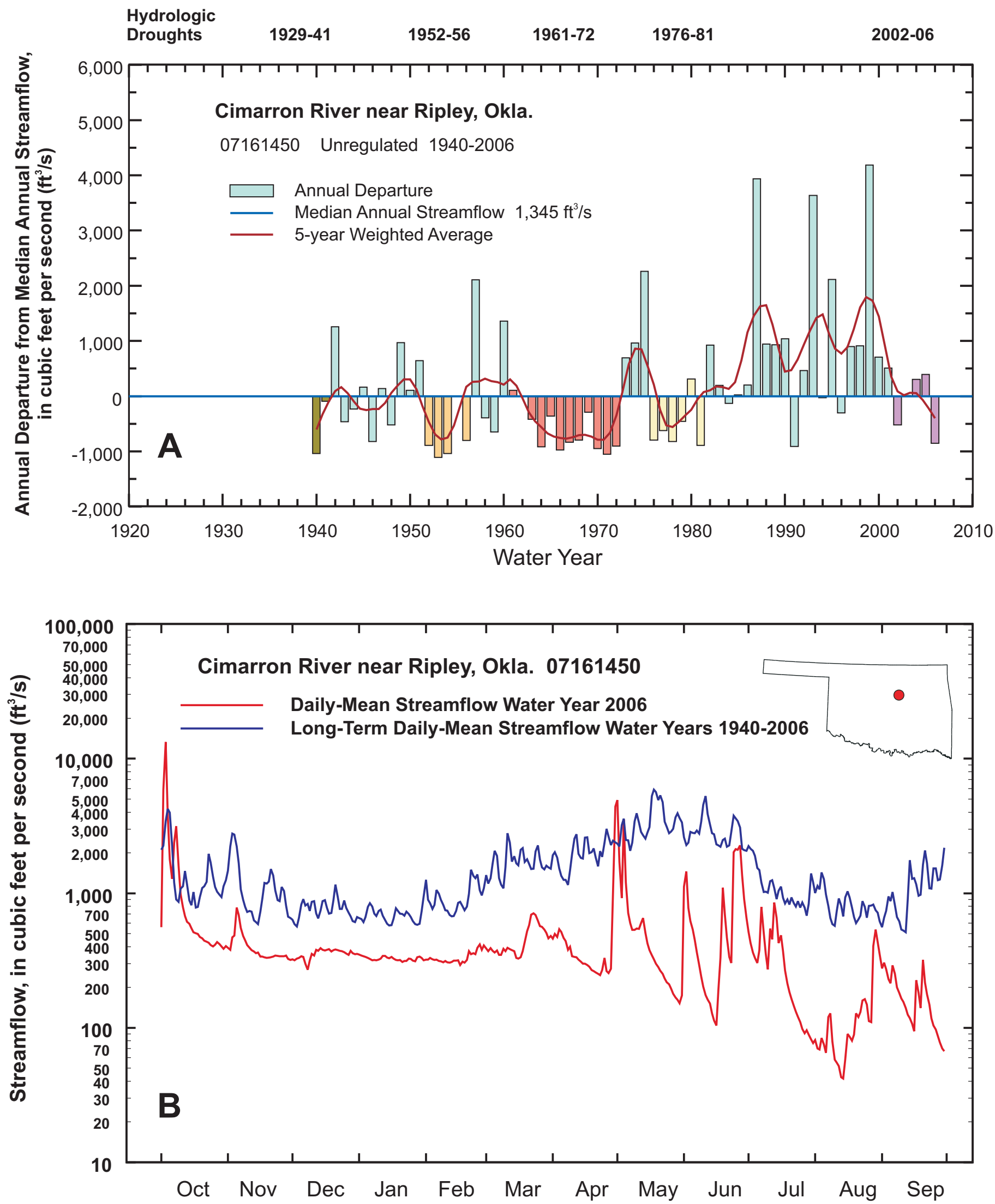

Figure 13. Cimarron River near Ripley $(A)$ annual departure from long-term median annual streamflow, water years 1940-2006 (B) comparing daily-mean streamflow of Water Year 2006 and long-term daily-mean streamflow, water years 1940-2006. Includes streamflow record 1940-87 from nearby station 0716100, Cimarron River at Perkins. 
Hydrologic Drought of Water Year 2006 Compared with Four Major Drought Periods of the 20th Century in Oklahoma
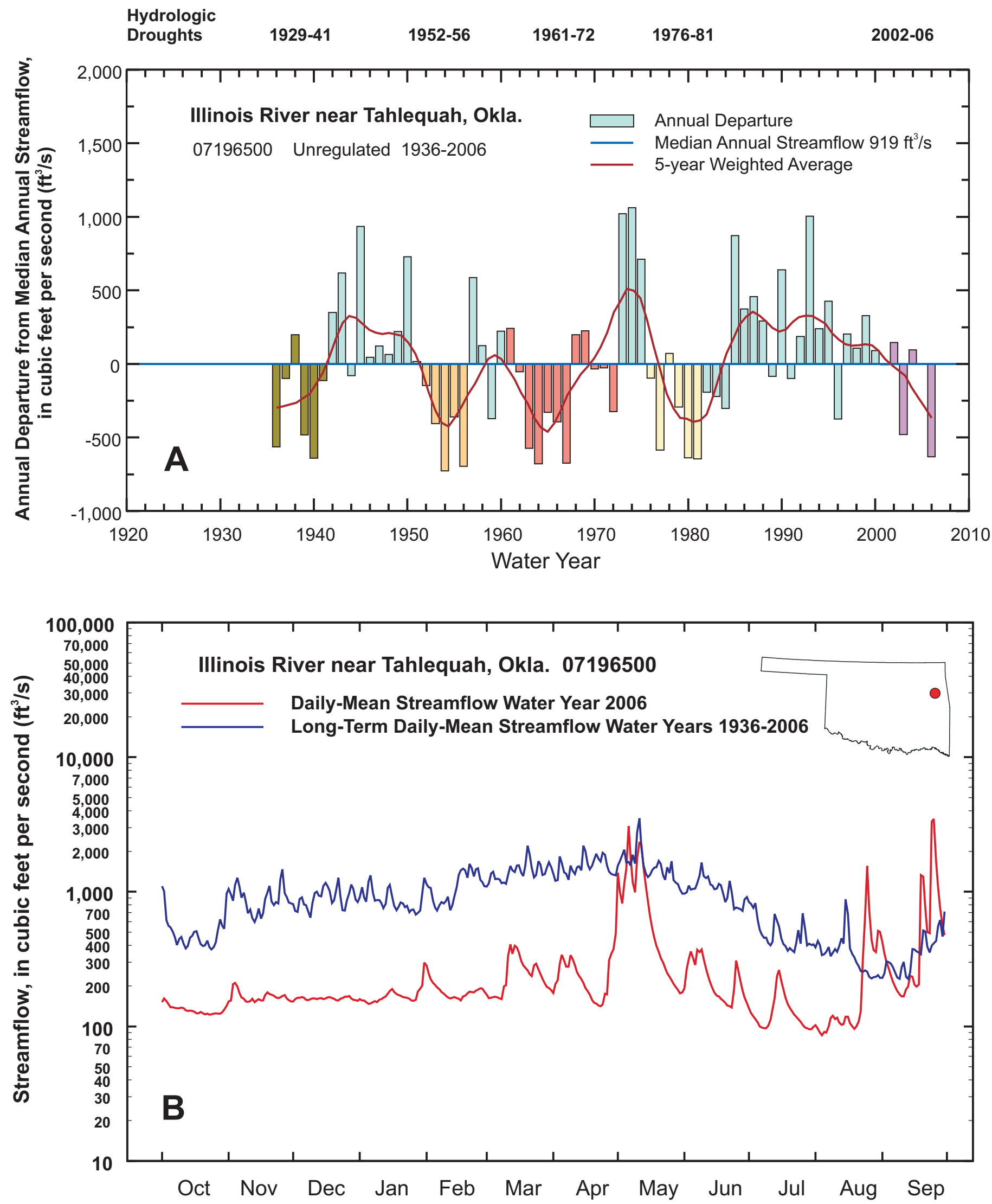

Figure 14. Illinois River near Tahlequah $(A)$ annual departure from long-term median annual streamflow, water years 1936-2006 (B) comparing daily-mean streamflow of Water Year 2006 and long-term daily-mean streamflow, water years 1936-2006. 

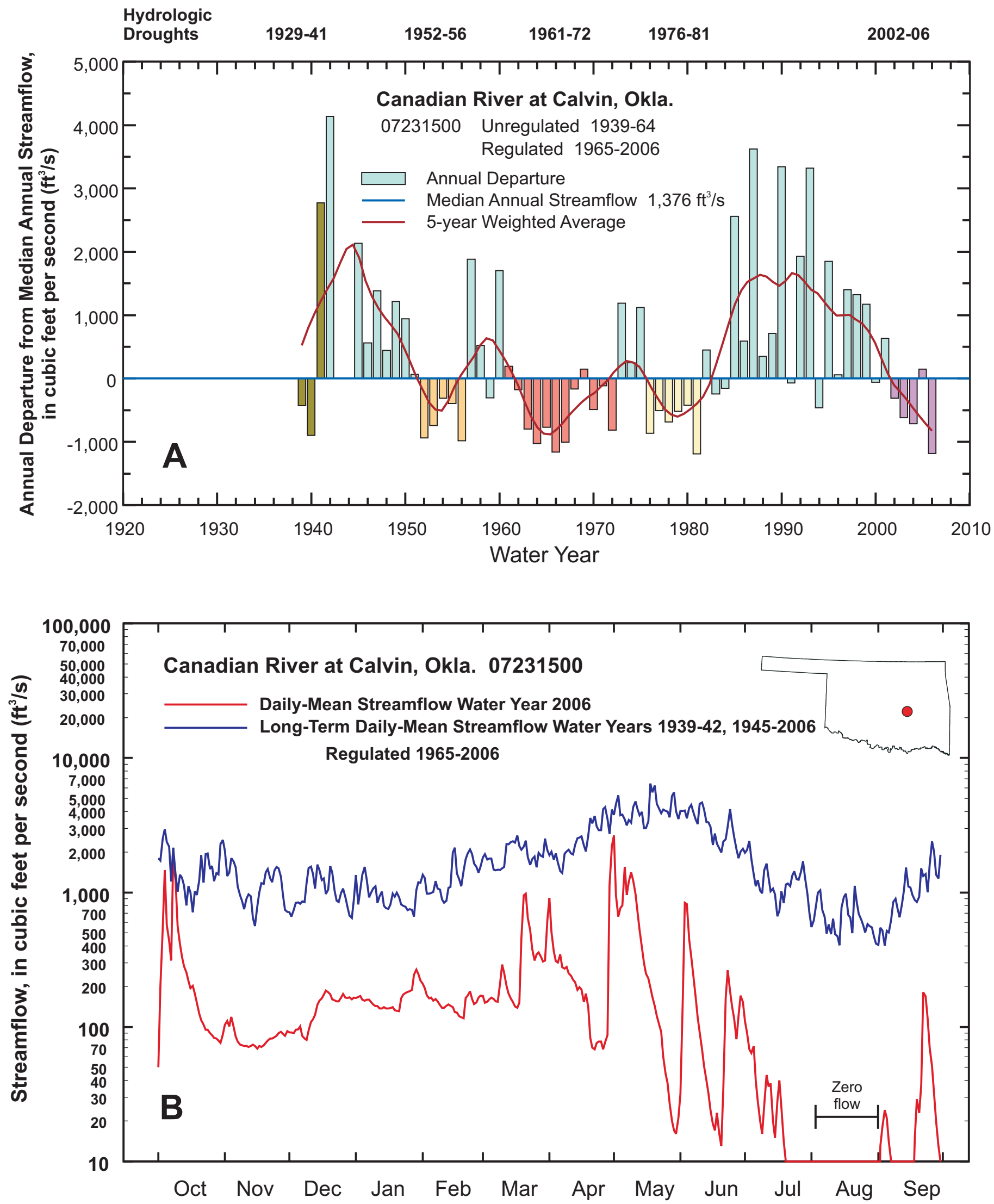

Figure 15. Canadian River at Calvin $(A)$ annual departure from long-term median annual streamflow, water years 1939-2006 (B) comparing daily-mean streamflow of Water Year 2006 and long-term daily-mean streamflow, water years 1939-2006. 
Hydrologic Drought of Water Year 2006 Compared with Four Major Drought Periods of the 20th Century in Oklahoma
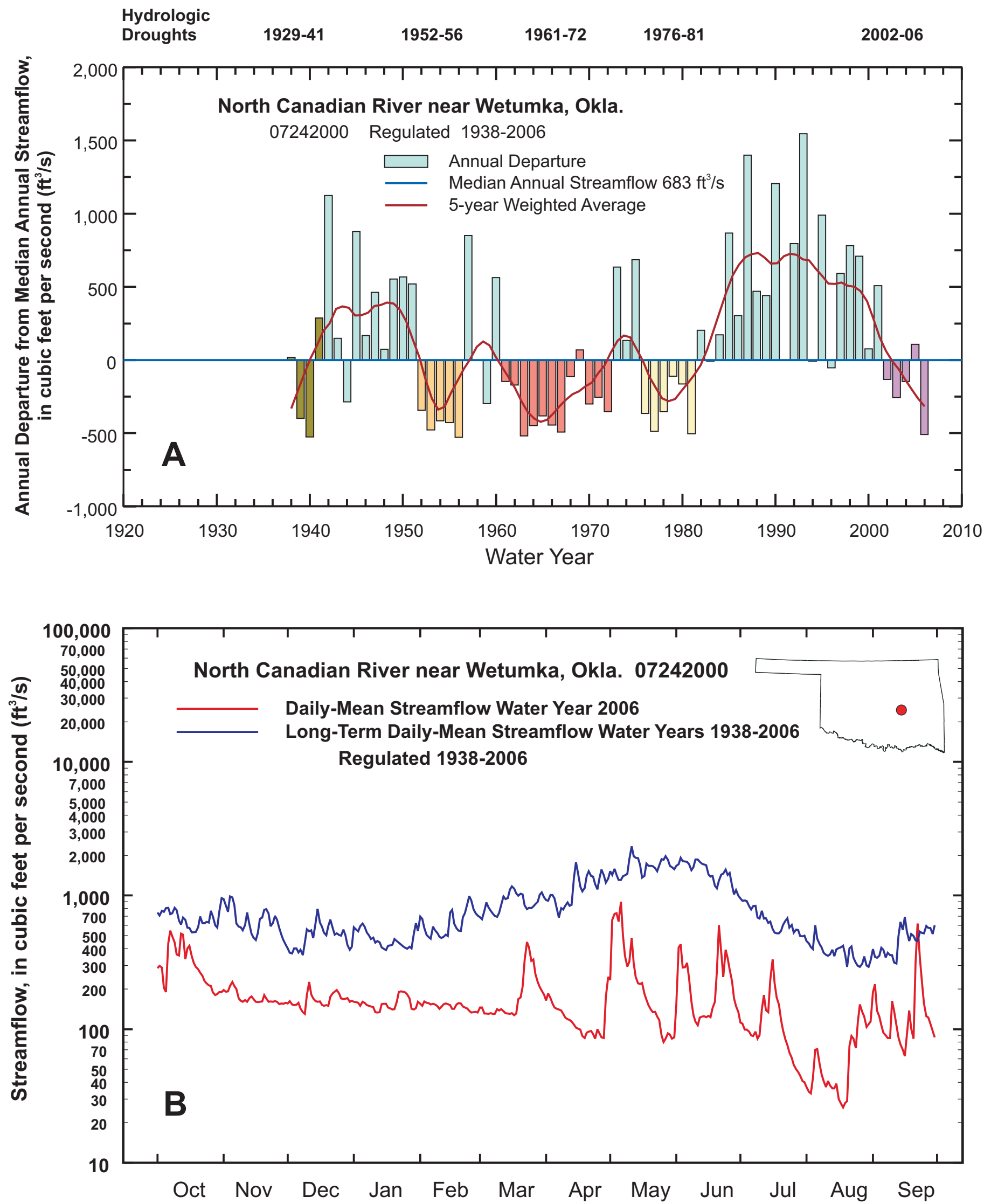

Figure 16. North Canadian River near Wetumka $(A)$ annual departure from long-term median annual streamflow, water years 1938-2006 (B) comparing daily-mean streamflow of Water Year 2006 and long-term daily-mean streamflow, water years 1938-2006. 

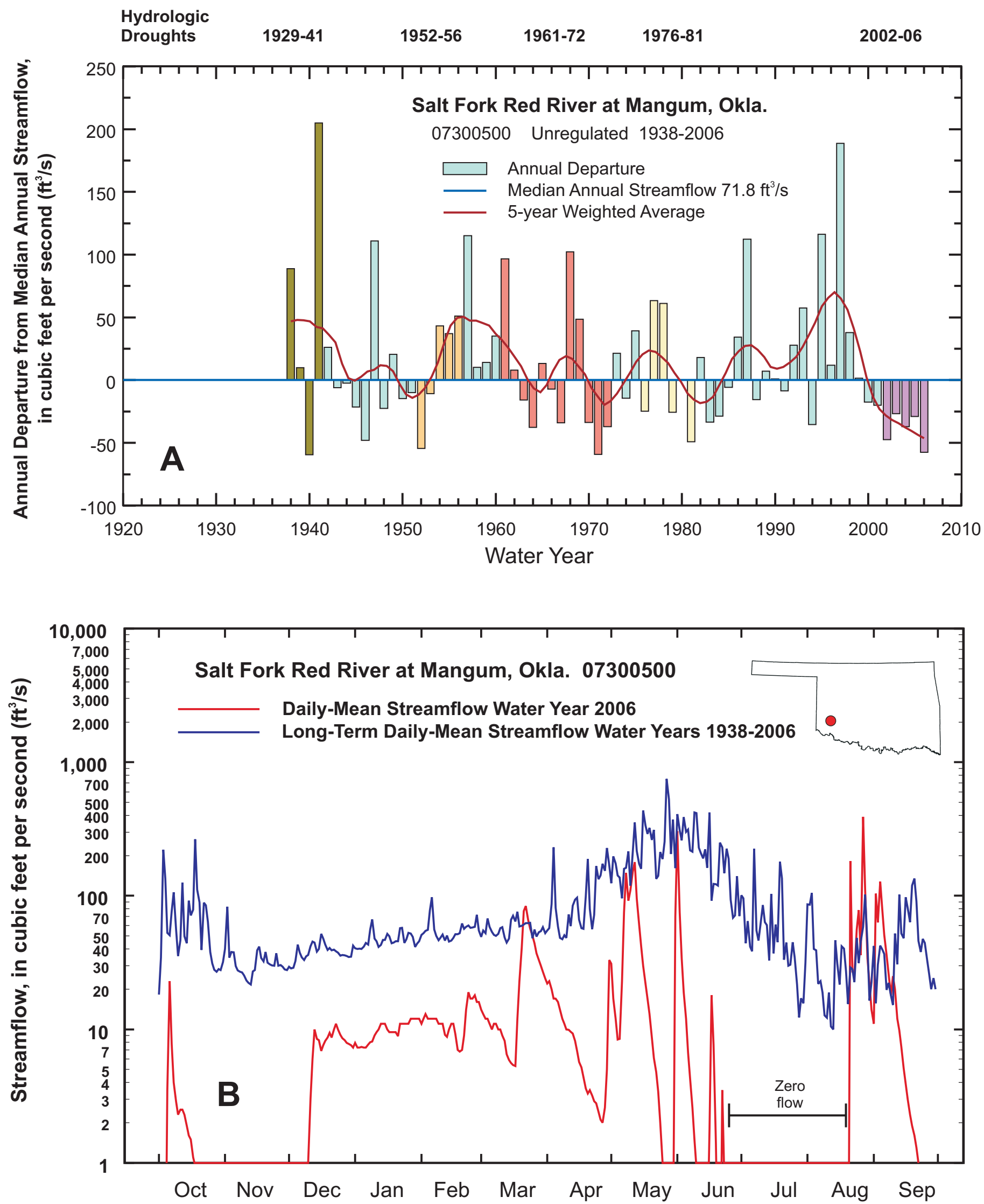

Figure 17. Salt Fork Red River at Mangum $(A)$ annual departure from long-term median annual streamflow, water years 1938-2006 (B) comparing daily-mean streamflow of Water Year 2006 and long-term daily-mean streamflow, water years 1938-2006. 

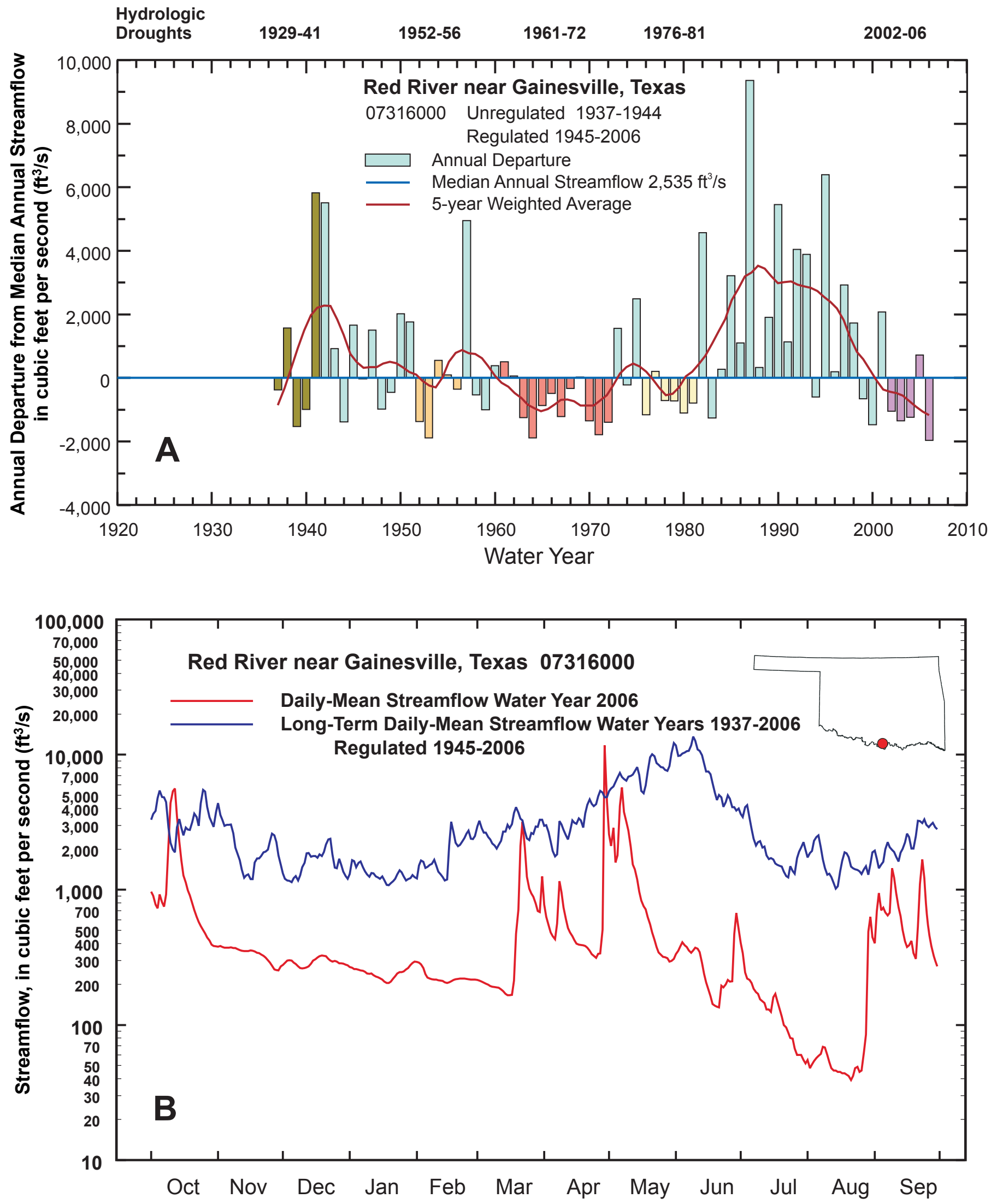

Figure 18. Red River near Gainesville, Texas, $(A)$ annual departure from long-term median annual streamflow, water years $1937-2006$ (B) comparing daily-mean streamflow of Water Year 2006 and long-term daily-mean streamflow, water years $1937-2006$. 
with 15 percent of normal annual flow. Zero flow was not recorded during Water Year 2006, with some wet periods in November, April-May, and August-September (fig. 11). The lowest flow was near the end of the water year in July (fig. 11; appendix 2; U.S. Geological Survey, 2008c).

\section{Cimarron River near Waynoka}

Cimarron River near Waynoka (07158000) is a streamflow-gaging site in northwest Oklahoma. Water Year 2006 was the $10^{\text {th }}$ driest in the 69 years of record from 1938-2006, with 42 percent of normal annual flow (table 2). Water Year 2002 was the third driest year, from the 2002-2006 drought period, with 20 percent of normal annual flow. Zero flow was recorded in Water Year 2006 during the first part of August (fig. 12). The lowest flow was at the end of the water year in first part of August and last part of September (fig. 12; appendix 3; U.S. Geological Survey, 2008c).

\section{Cimarron River near Ripley}

Cimarron River near Ripley (07161450) is a streamflowgaging site in central Oklahoma. Water Year 2006 was the $12^{\text {th }}$ driest in the 67 years of record from 1940-2006, with 37 percent of normal annual flow (table 2). Water Year 1953 was the driest year, from the 1952-56 drought period, with 17 percent of normal annual flow. Zero flow was not recorded during Water Year 2006, with some wet periods in October, May-July, and August-September (fig. 13). The lowest flow was near the end of the water year in August (fig. 13; appendix 4; U.S. Geological Survey, 2008c).

\section{Illinois River near Tahlequah}

Illinois River near Tahlequah (07196500) is a streamflow-gaging site in east-central Oklahoma. Water Year 2006 was the $8^{\text {th }}$ driest in the 71 years of record from 1936-2006, with just 31 percent of normal annual flow (table 2). Water Year 1954 was the driest year, from the 1952-56 drought period, with 21 percent of normal annual flow. Zero flow was not recorded during Water Year 2006, with some wet periods in May, August, and September (fig. 14). The lowest flow was near the end of the water year in August (fig. 14; U.S. Geological Survey, 2008c).

\section{Canadian River at Calvin}

Canadian River at Calvin (07231500) is a streamflowgaging site in east-central Oklahoma. Water Year 2006 was the second driest in the 66 years of record from 1939-42, 1945-2006; with just 14 percent of normal annual flow (table 2). Water Year 1981 was the driest year, from the 1976-81 drought period, with 13 percent of normal annual flow. Zero flow was recorded in Water Year 2006 during most of the month of August with some wet periods in October and March through June (fig. 15). The lowest flow was at the end of the water year in August and September (fig. 15; U.S. Geological Survey, 2008c).

Daniel Fenner of U.S. Fish and Wildlife Service (written commun., 2006) photographically documented no flow or little flow during mid-August on the reach of the Canadian River near Thomas upstream from the streamflow-gaging site at Bridgeport to near Ada, just upstream from the streamflowgaging site at Calvin (fig. 9, appendix 5).

\section{North Canadian River near Wetumka}

North Canadian River near Wetumka (07242000) is a streamflow-gaging site in central Oklahoma. Water Year 2006 was the fourth driest in the 69 years of record from 1938-2006, with just 26 percent of normal annual flow (table 2). Water Year 1956 was the driest year, from the 1952-56 drought period, with 23 percent of normal annual flow. Zero flow was not recorded during Water Year 2006, with some wet periods in October, March through June and September (fig. 16). The lowest flow was near the end of the water year in August (fig. 16; U.S. Geological Survey, 2008c).

\section{Salt Fork Red River at Mangum}

Salt Fork Red River near Mangum (07300500) is a streamflow-gaging site in southwest Oklahoma. Water Year 2006 was the third driest in the 69 years of record from 1938-2006, with just 20 percent of normal annual flow (table 2). Water Year 1940 was the driest year, from the 1929-41 drought period, with 17 percent of normal annual flow. Zero flow was recorded in Water Year 2006 during late June through August, with some wet periods in October, March through June and late August and September (fig. 17; U.S. Geological Survey, 2008c). Low flow was recorded from October through March, and some days in April through September (fig. 17).

\section{Red River near Gainesville, Texas}

Red River near Gainesville, Texas, (07316000) is a streamflow-gaging site in south-central Oklahoma. Water Year 2006 was the driest in the 70 years of record from 1937-2006, with just 22 percent of normal annual flow (table 2). Water Year 1953 was second driest year, from the 1952-56 drought period, with 26 percent of normal flow. Zero flow was not recorded during Water Year 2006, with some wet periods in October, March, May, and September (fig. 18). The lowest flow was near the end of the water year in August (fig. 18, U.S. Geological Survey, 2008c). 


\section{Washita River near Dickson}

Washita River near Dickson (07331000) is a streamflowgaging site in south-central Oklahoma. Water Year 2006 was the second driest in the 78 years of record from 1929-2006, with just 27 percent of normal annual flow (table 2). Water Year 1964 was the driest year, from the 1961-72 drought period, with 24 percent of normal annual flow. Zero flow was not recorded during Water Year 2006, with some wet periods in October, March, May, and September (fig. 19). The lowest flow was near the end of the water year in August (fig. 19; appendix 6; U.S. Geological Survey, 2008c).

\section{Blue River near Blue}

Blue River near Blue (07332500) is a streamflow-gaging site in south-central Oklahoma. Water Year 2006 was the fifth driest in the 70 years of record from 1937-2006, with just 31 percent of normal annual flow (table 2). Water Year 1956 was the driest year, from the 1952-56 drought period, with 12 percent of normal annual flow. Zero flow was not recorded during Water Year 2006, with some wet periods in March through May (fig. 20). The lowest flow was near the end of the water year in August and September (fig. 20; U.S. Geological Survey, 2008c).

\section{Red River at Arthur City, Texas}

Red River at Arthur City, Texas (07335500) is a streamflow-gaging site in southeast Oklahoma. Water Year 2006 was the driest in the 62 years of record from 1945-2006, with just 25 percent of normal annual flow (table 2). Water Year 1964 was the second driest year, from the 1961-72 drought period, with 38 percent of normal annual flow. Zero flow was not recorded during Water Year 2006, with some wet periods in March through May (fig. 21). The lowest flow was near the end of the water year in August and September (fig. 21; U.S. Geological Survey, 2008c).

\section{Effects of Low Streamflows}

Hydrologic drought is associated with the effects of periods of precipitation deficits on streamflow, lake and reservoir levels, and ground water. Although all droughts start with precipitation deficits, hydrologists are more concerned with how this deficit affects the hydrologic system. Hydrologic droughts commonly lag the meteorological and agricultural droughts. During hydrologic droughts, precipitation deficiencies take longer to show up in components of the hydrologic system. For example, precipitation deficits may result in a rapid depletion of soil moisture that has an immediate effect on agriculture (Jackson, 2006a), but the effect on reservoir levels may not affect water supply, hydroelectric power production, or recreational uses for several months. Water in the hydrologic storage systems, rivers and reservoirs, commonly has multiple and competing purposes including flood control, irrigation, recreation, navigation, hydropower, and wildlife habitat. Competition for this water escalates during drought and conflicts between water users increase substantially (National Drought Mitigation Center, 2006a).

\section{Conditions at Major Reservoirs}

The hydrologic drought of Water Year 2006 substantially affected the reservoirs in the state. The effects on 31 selected major lakes or reservoirs at three times of the water year are presented in table 3 (fig. 22; Oklahoma Water Resources Board, 2006b; U.S. Army Corps of Engineers, 2007). Table 3 shows the conservation storage in these lakes, expressed both in terms of volume and percent of conservation storage, on October 4, 2006, a few days after the end of the Water Year 2006. On that day the statewide total conservation storage was 86.3 percent. Table 3 also compares levels at these reservoirs, expressed as percent of conservation storage, on two other days: (1) the levels on December 21, 2005, when the statewide total conservation storage was lowest, 84.5 percent, and (2) May 24, 2006, when the statewide total conservation storage was the highest, 96.8 percent. The north-central region of the state consistently had the highest percent of conservation storage (or wettest) while the southwest region of the state consistently had the lowest percent of conservation storage (or driest) at all three times of the water year. Lake Altus at Lugert (site 21, fig. 22) in the southwest region was the driest reservoir for the entire water year (appendix 7).

Lake Eufaula (site 18, fig. 22) is a good example of the dependence several water-use customers have on the reservoirs. Six municipalities, eight rural water districts, a hydroelectric plant, and natural gas plant all use water from the lake in addition to recreational use (Jackson, 2006b). However, it must be noted that the condition of farm ponds across Oklahoma was more drastically affected than the major reservoirs. Hundreds of farm ponds across Oklahoma had completely dried up by January 15, 2006 (Jackson, 2006b).

\section{Hydroelectric Power Generation}

Hydroelectric power in Oklahoma was greatly reduced during Water Year 2006 because of reduction in available streamflow as a result of the hydrologic drought. Table 4 illustrates the drastic reduction in hydroelectric power generation at selected hydroelectric plants from Calendar Year 2005 to Water Year 2006. Even though there was a 3-month overlap between October through December 2005, the Water Year 2006 hydroelectric power generation at sites in Oklahoma was only 7 to 47 percent of the Calendar Year 2005 power generation (table 4). 

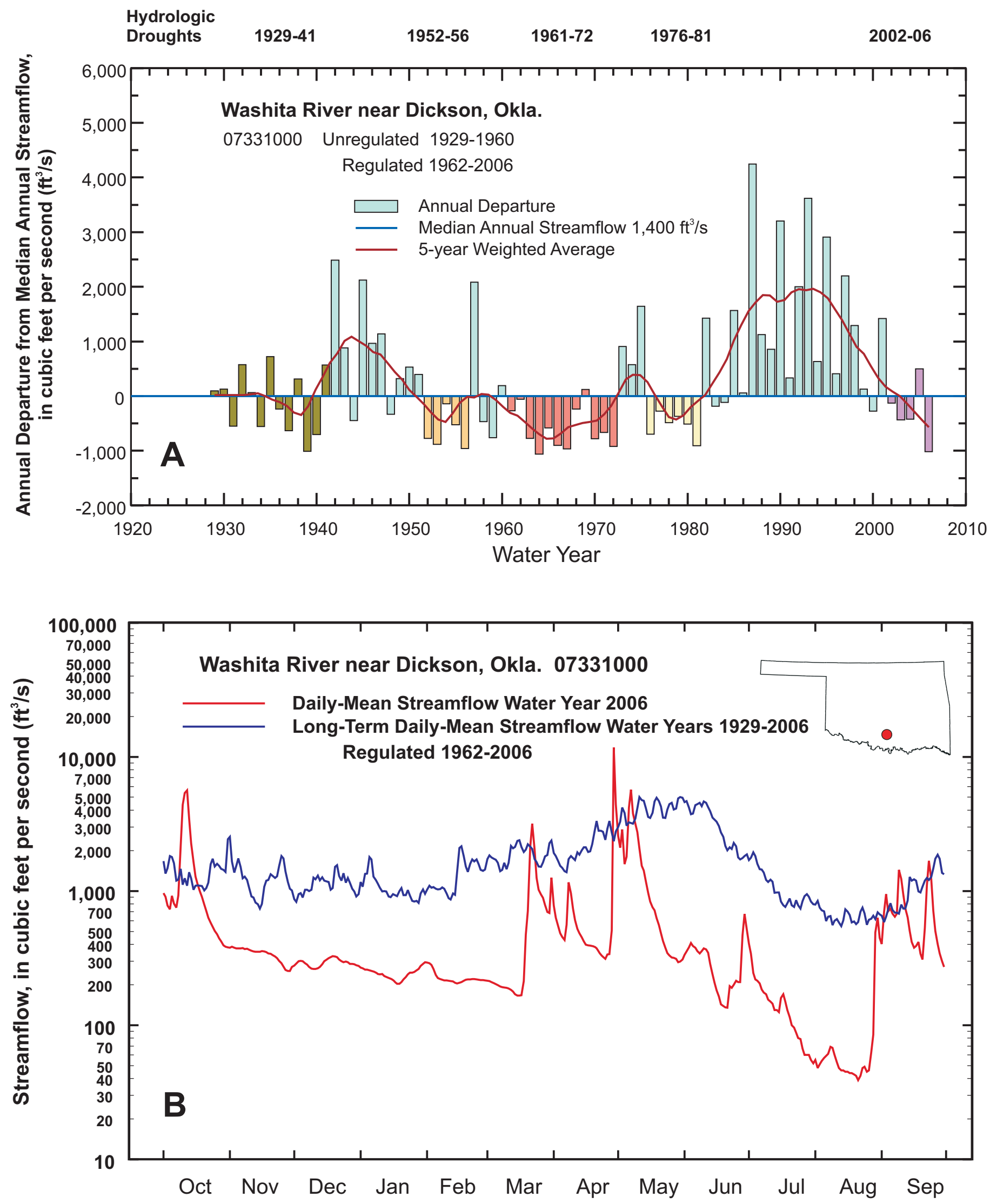

Figure 19. Washita River near Dickson $(A)$ annual departure from long-term median annual streamflow, water years 1929-2006 (B) comparing daily-mean streamflow of Water Year 2006 and long-term daily-mean streamflow, water years 1929-2006. 

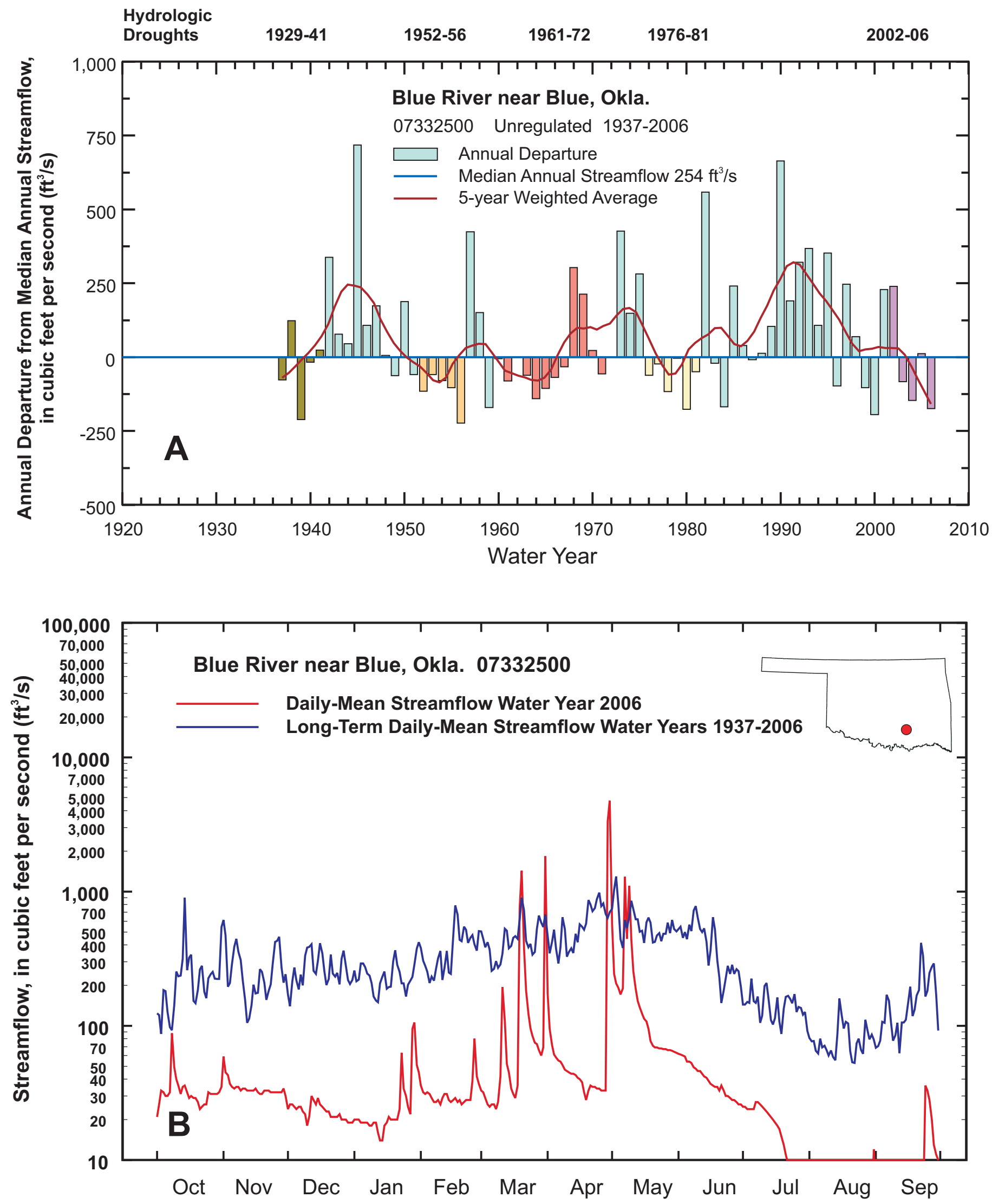

Figure 20. Blue River near Blue $(A)$ annual departure from long-term median annual streamflow, water years $1937-2006(B)$ comparing daily-mean streamflow of Water Year 2006 and long-term daily-mean streamflow, water years 1937-2006. 

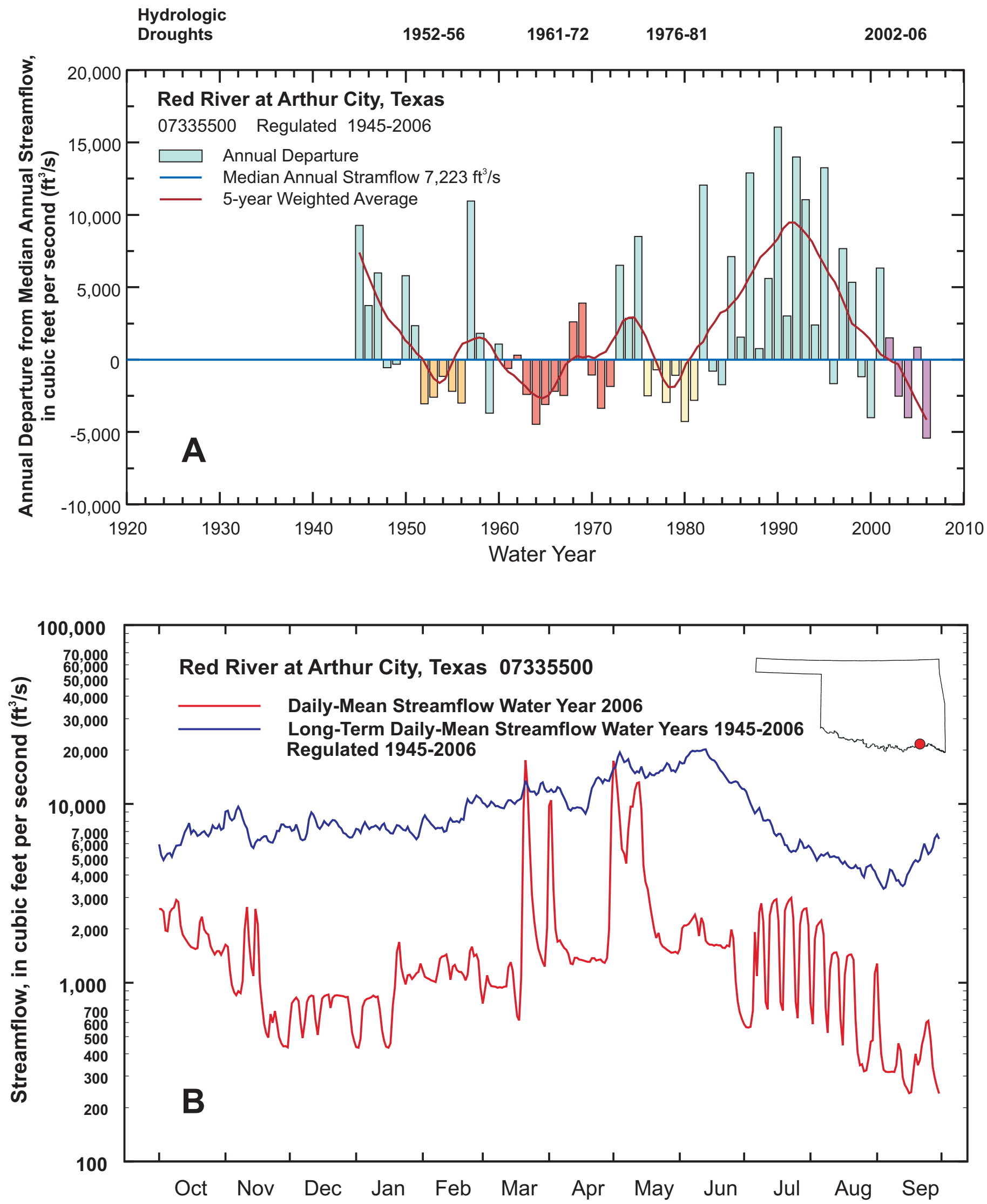

Figure 21. Red River at Arthur City, Texas, $(A)$ annual departure from long-term median annual streamflow, water years $1945-2006$ (B) comparing daily-mean streamflow of Water Year 2006 and long-term daily-mean streamflow, water years 1945-2006. 


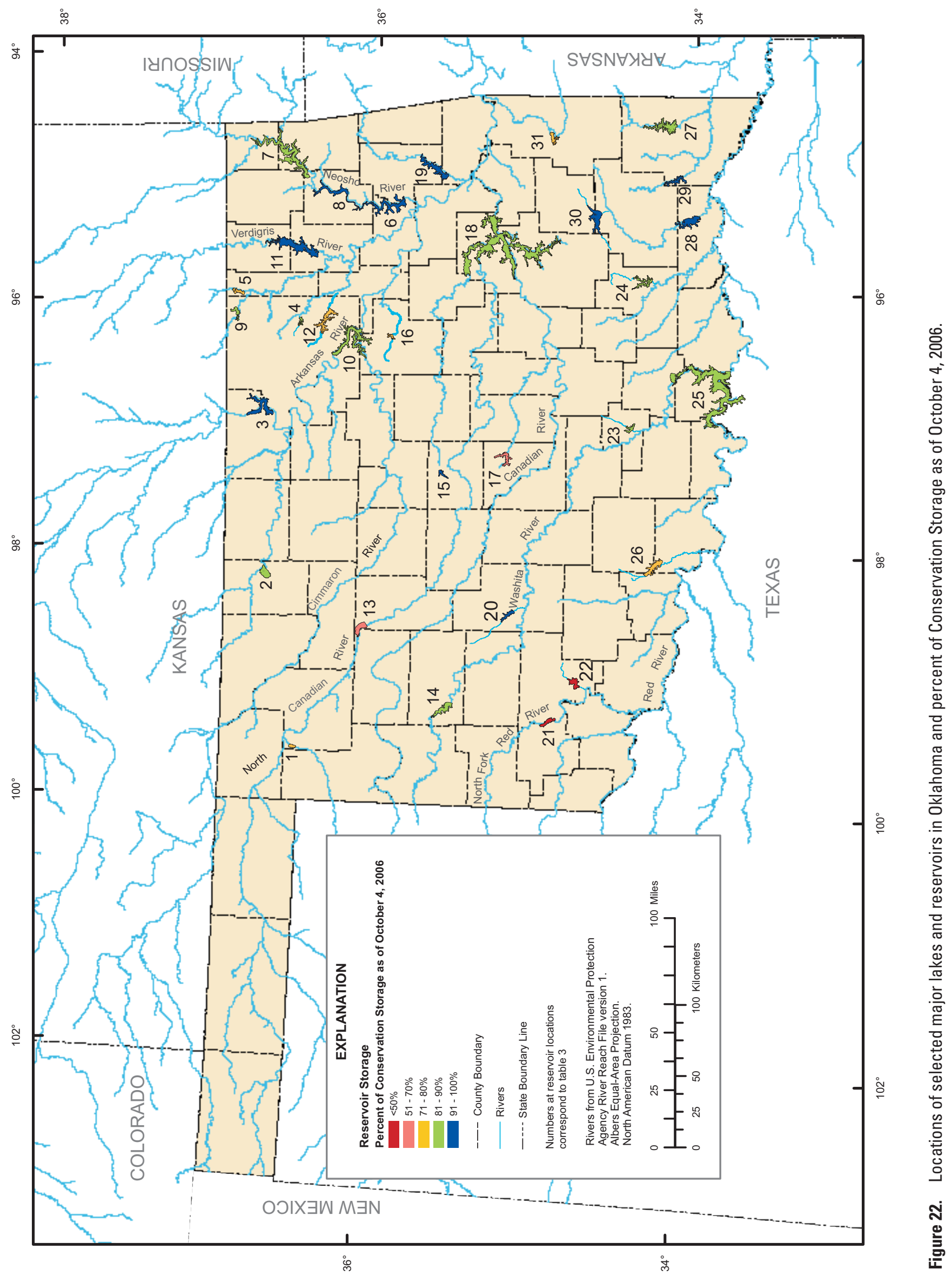


Table 3. Storage in selected major Oklahoma lakes and reservoirs during October 4, 2006, by National Weather Service Climate Division, and comparison with December 21, 2005, and May 24, 2006, storage.

[Shading indicates reservoir storage below 80 percent of total conservation storage; WY, Water Year]

\begin{tabular}{|c|c|c|c|c|c|c|}
\hline \multirow[b]{2}{*}{$\begin{array}{c}\text { Site } \\
\text { number } \\
\text { (fig. 22) }\end{array}$} & \multirow[b]{2}{*}{$\begin{array}{l}\text { Climate Division } \\
\text { Lake or Reservoir }\end{array}$} & \multirow{2}{*}{$\begin{array}{c}\text { Conservation } \\
\text { storage } \\
\text { (acre-feet) }\end{array}$} & \multirow{2}{*}{$\begin{array}{c}\text { 10/04/06 } \\
\text { storage } \\
\text { (acre-feet) }\end{array}$} & \multicolumn{3}{|c|}{ Percent of conservation storage } \\
\hline & & & & $\begin{array}{l}\text { WY end } \\
10 / 4 / 2006^{a}\end{array}$ & $\begin{array}{l}\text { WY driest } \\
12 / 21 / 2005^{b}\end{array}$ & $\begin{array}{l}\text { WY wettest } \\
5 / 24 / 2006^{c}\end{array}$ \\
\hline
\end{tabular}

2-North Central

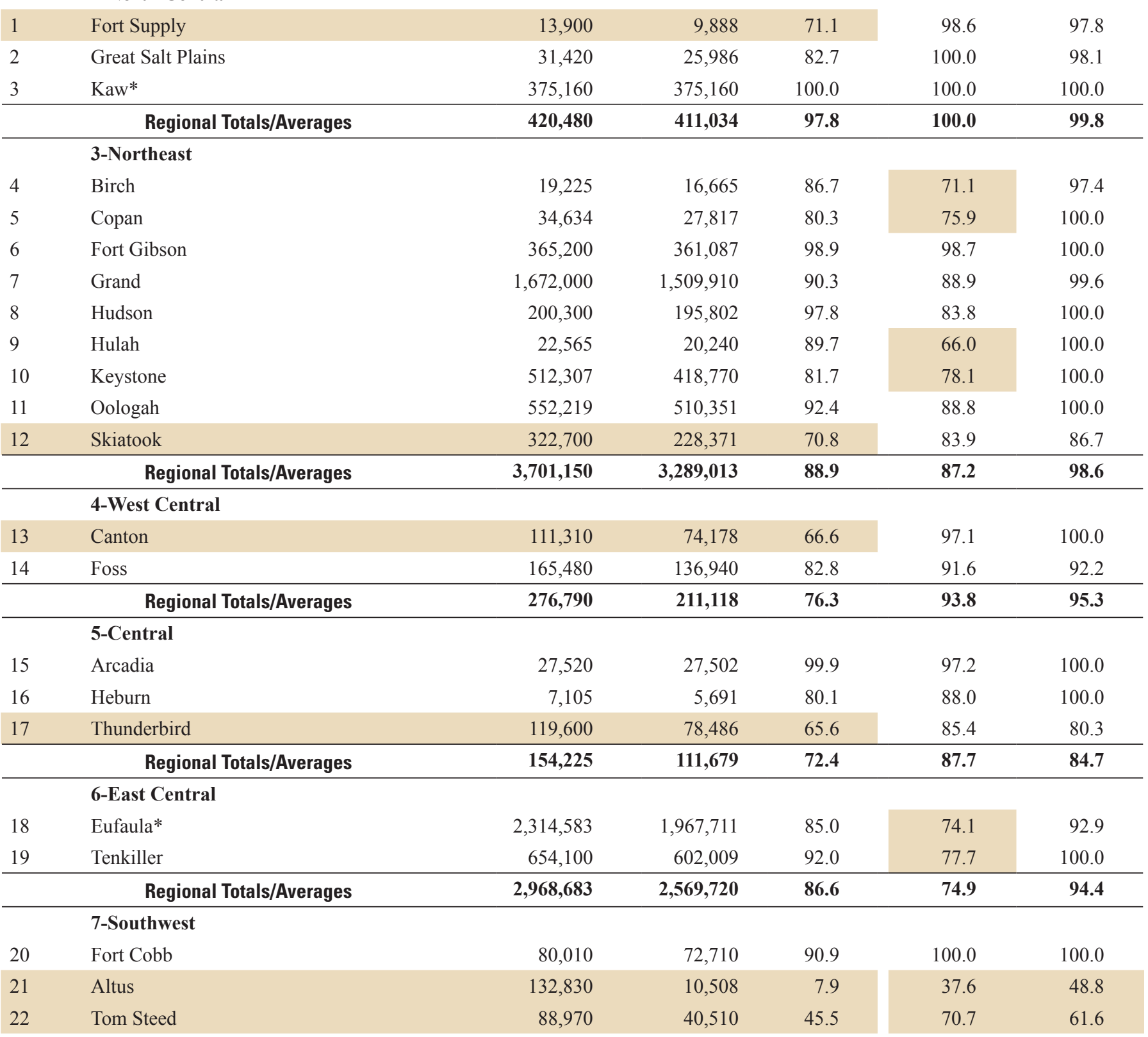


Table 3. Storage in selected major Oklahoma lakes and reservoirs during October 4, 2006, by National Weather Service Climate Division, and comparison with December 21, 2005, and May 24, 2006, storage. - Continued

[Shading indicates reservoir storage below 80 percent of total conservation storage; WY, Water Year]

\begin{tabular}{|c|c|c|c|c|c|c|}
\hline \multirow[b]{2}{*}{$\begin{array}{c}\text { Site } \\
\text { number } \\
\text { (fig. 22) }\end{array}$} & \multirow{2}{*}{$\begin{array}{l}\text { Climate Division } \\
\text { Lake or Reservoir }\end{array}$} & \multirow{2}{*}{$\begin{array}{l}\text { Conservation } \\
\text { storage } \\
\text { (acre-feet) }\end{array}$} & \multirow{2}{*}{$\begin{array}{c}10 / 04 / 06 \\
\text { storage } \\
\text { (acre-feet) }\end{array}$} & \multicolumn{3}{|c|}{ Percent of conservation storage } \\
\hline & & & & $\begin{array}{l}\text { WY end } \\
10 / 4 / 2006 \text { a }\end{array}$ & $\begin{array}{l}\text { WY driest } \\
12 / 21 / 2005^{b}\end{array}$ & $\begin{array}{l}\text { WY wettest } \\
5 / 24 / 2006^{\circ}\end{array}$ \\
\hline & Regional Totals/Averages & 301,810 & 123,728 & 41.0 & 63.9 & 66.1 \\
\hline & 8-South Central & & & & & \\
\hline 23 & Arbuckle & 72,400 & 63,165 & 87.2 & 95.9 & 100.0 \\
\hline 24 & McGee Creek & 113,930 & 96,505 & 84.7 & 89.6 & 100.0 \\
\hline 25 & Texoma* & $2,556,122$ & $2,257,985$ & 88.3 & 92.4 & 100.0 \\
\hline \multirow[t]{3}{*}{26} & Waurika* & 190,200 & 139,059 & 73.1 & 93.3 & 89.2 \\
\hline & Regional Totals/Averages & $2,932,652$ & $2,556,714$ & 87.2 & 92.4 & 99.3 \\
\hline & 9- Southeast & & & & & \\
\hline 27 & Broken Bow* & 954,175 & 796,073 & 83.4 & 77.5 & 97.4 \\
\hline 28 & Hugo* & 158,617 & 158,617 & 100.0 & 66.5 & 100.0 \\
\hline 29 & Pine Creek* & 53,750 & 53,750 & 100.0 & 80.6 & 100.0 \\
\hline 30 & Sardis & 274,330 & 252,137 & 91.9 & 90.1 & 100.0 \\
\hline \multirow[t]{4}{*}{31} & Wister & 60,162 & 47,915 & 79.6 & 62.6 & 100.0 \\
\hline & Regional Totals/Averages & $1,501,034$ & $1,308,492$ & 87.2 & 78.0 & 98.4 \\
\hline & State Totals & $12,256,824$ & $10,581,498$ & 86.3 & 84.5 & 96.8 \\
\hline & Reservoirs below 80 percent Storage & & & 8 & 11 & 2 \\
\hline
\end{tabular}

* indicates seasonal pool operation; actual storage figures/percents may vary

a WY end, 10/4/2006, approximates end of WY 2006 State Total Conservation Storage (Oklahoma Water Resources Board, 2006a).

${ }^{\mathrm{b}}$ WY driest, 12/21/2005, approximates lowest State Total Conservation Storage for WY 2006 (Oklahoma Water Resources Board, 2005).

${ }^{c}$ WY wettest, 5/24/2006, approximates highest State Total Conservation Storage for WY 2006 (Oklahoma Water Resources Board, 2006b).

\section{Ground Water at a Long-Term Site}

A long-term recording ground-water well that has a close hydraulic connection between streams and the aquifer illustrates the effect the Water Year 2006 drought had on groundwater levels in south-central Oklahoma. Figure 23 shows the daily ground-water levels in the Fittstown well during Water Year 2006 (red line; U.S. Geological Survey, 2007f) compared to the long-term mean-daily water level (blue line; U.S. Geological Survey, 2008e). The water level was almost 17 feet lower than normal in March; although, late spring rains caused a rise in water levels in May. At the end of the water year the water level was more than 9 feet lower than normal.

\section{Wildfires}

Fire danger was critical because of the drought starting in November 2005. Hundreds of homes had been destroyed and nearly 600,000 acres were burned by January 2006 (Knapp, 2006; Slater, 2006). In a 24-hour period starting January 1 , 2006, more than 30 separate fires burned more than 81,000 acres and more than a dozen homes were lost (Knapp, 2006). Governor Brad Henry issued a statewide burn ban in November 2005 that remained in effect, though discontinued several times, until the last counties were removed from the ban on December 4, 2006.

\section{Summary}

Water Year 2006 (October 1, 2005, to September 30, 2006) was a year of extreme hydrologic drought and the driest year in the recent 2002-2006 drought in Oklahoma. The severity of this recent drought can be evaluated by comparing it with four previous major hydrologic droughts, water years 1929-41, 1952-56, 1961-72, and 1976-81.

The period of water years 1925-2006 was selected as the period of record because before 1925 few continuous record streamflow-gaging sites existed and gaps existed where no streamflow-gaging sites were operated. Statewide annual precipitation in Water Year 2006 was second driest with 
72 percent of normal precipitation and statewide annual runoff in Water Year 2006 was sixth driest in the 82 years of record.

Annual area-averaged precipitation totals by the nine National Weather Service Climate Divisions from Water Year 2006 are compared to those during four previous major hydrologic droughts in the 20th century to show how rainfall deficits in Oklahoma varied by region. Only two of the nine climate divisions, Climate Division 1 Panhandle and Climate Division 4 West Central, had minor rainfall deficits, with 85 percent or more of normal precipitation; while the rest of the climate divisions had severe rainfall deficits in Water Year 2006 ranging from only 65 to 73 percent of normal annual precipitation. The East Central, Southwest, and South Central Climate Divisions were hardest hit with only 65 to 67 percent of normal annual precipitation.

Regional streamflow patterns for Water Year 2006 indicate that Oklahoma was part of the regionwide below-normal streamflow conditions for Arkansas-White-Red River Basin, the sixth driest since 1930. The percentage of long-term stations in Oklahoma (with at least 30 years of record) having below-normal streamflow reached 80 to 85 percent for some days in August and November 2006.

Twelve long-term streamflow-gaging sites with periods of record ranging from 62 to 78 years were selected to show how streamflow deficits varied by region. The hydrologic drought worsened going from north to south in Oklahoma, ranging from 45 percent in the north, to just 14 percent in east-central Oklahoma, and 20 percent of normal annual streamflow in the southwest. The Chikaskia River near Blackwell and the Cimarron River near Waynoka in north-central Oklahoma had 45 and 42 percent of normal annual streamflow during Water Year 2006, respectively. The Canadian River at Calvin in east-central Oklahoma had only 14 percent of normal annual streamflow, the second driest year in 66 years; the Salt Fork Red River near Mangum in southwest Oklahoma had only 20 percent of normal annual streamflow, the third driest in the 69 years of record and the Red River near Gainesville in south-central Oklahoma had only 22 percent of normal annual streamflow, the driest year in 70 years.

Some effects of low streamflows during Water Year 2006 include (1) major reservoirs had only 86.3 percent of

Table 4. Comparison of hydroelectric power generation at selected Oklahoma hydroelectric plants between Calendar Year 2005 and Water Year 2006.

[GWh, Gigawatt-hour; CY, calendar year]

\begin{tabular}{|c|c|c|c|c|c|}
\hline \multirow[b]{2}{*}{$\begin{array}{c}\text { Site } \\
\text { number } \\
\text { (fig.22) }\end{array}$} & \multirow[b]{2}{*}{$\begin{array}{c}\text { Lake } \\
\text { hydroelectric } \\
\text { generation project }\end{array}$} & \multirow[b]{2}{*}{ Climate division } & \multirow{2}{*}{$\begin{array}{c}\text { Calendar Year } \\
2005 \\
\text { power } \\
\text { (GWh) }\end{array}$} & \multicolumn{2}{|c|}{ Water Year 2006} \\
\hline & & & & $\begin{array}{l}\text { Power } \\
\text { (GWh) }\end{array}$ & $\begin{array}{l}\text { Percent of } \\
\text { CY } 2005 \\
\text { power }\end{array}$ \\
\hline 3 & Kaw $^{1}$ & 2-North Central & 130 & 36 & 28 \\
\hline 6 & Fort Gibson ${ }^{2}$ & 3-Northeast & 231 & 46 & 20 \\
\hline 7 & Grand (Pensacola) ${ }^{3}$ & 3-Northeast & 452 & 101 & 22 \\
\hline 8 & Hudson (RS Kerr) ${ }^{3}$ & 3-Northeast & 235 & 40 & 17 \\
\hline 8 & Salina $^{3,4}$ & 3-Northeast & 276 & 130 & 47 \\
\hline 10 & Keystone $^{2}$ & 3-Northeast & 310 & 113 & 36 \\
\hline 18 & Eufaula $^{2}$ & 6-East Central & 192 & 13 & 7 \\
\hline 19 & Tenkiller $^{2}$ & 6-East Central & 95 & 21 & 22 \\
\hline 27 & Broken Bow ${ }^{2}$ & 9-Southeast & 98 & 29 & 30 \\
\hline
\end{tabular}

\footnotetext{
${ }^{1}$ Data from Oklahoma Municipal Power Authority (OMPA) Calendar Year 2005 data from R. Morecroft (OMPA, written commun., 2008). Water Year 2006 data from D. Osburn (OMPA, written commun., 2008).

${ }^{2}$ Data from Department of Energy, Southwestern Power Administration (SWPA), Calendar Year 2005 data from J. Croton (SWPA, written commun., 2007), and Water Year 2006 data from Southwestern Power Administration (2007).

${ }^{3}$ Data from Grand River Dam Authority (GRDA). All data from A. Bishop (GRDA, written commun., 2007)

${ }^{4}$ Salina Pumped Storage Project, Chimney Rock Reservoir. Water used on the Salina Creek Arm of Lake Hudson, classified as offstream project.
} 


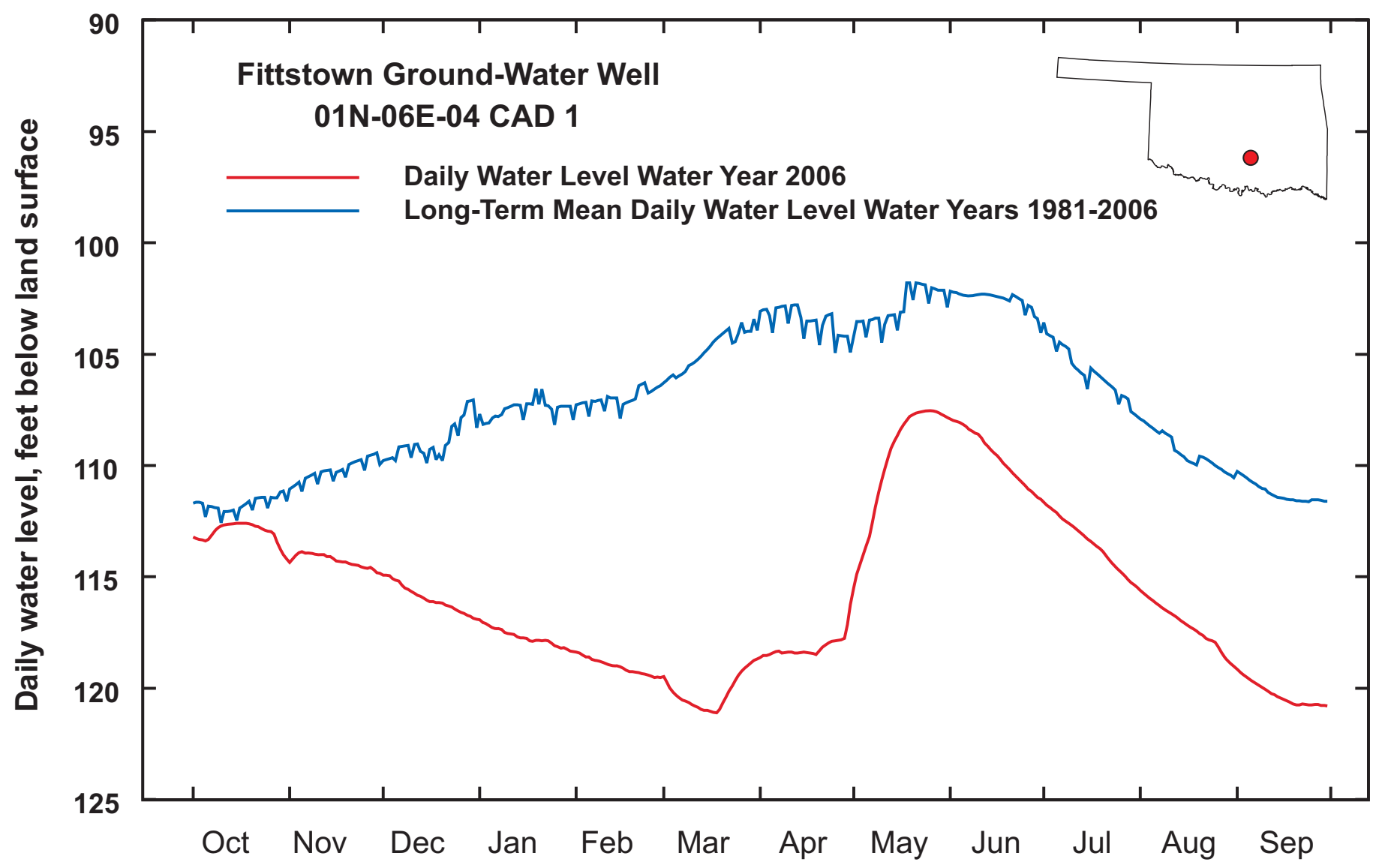

Figure 23. Fittstown ground-water well, comparing daily water levels for Water Year 2006 and long-term mean-daily water levels, water years 1981-2006.

the statewide conservation storage available at the end of the water year, (2) hydroelectric power generation at sites in Oklahoma was only 7 to 47 percent of the Calendar Year 2005 power generation, (3) ground water at a long-term site in south-central Oklahoma had a drop in water level of more than 17 feet lower than normal, and (4) wildfires burned more than 600,000 acres.

\section{Selected References}

Bisbee, Julie, 2006, Lack of rain forces producers to sell cattle: The Oklahoman, July 11, 2006, accessed March 6, 2008, at http://www.newsok.com/article/keyword/2000621/

Blazs, R.L., Walters, D.M., Coffey, T.E., Boyle, D.L., and Wellman, J.J., 2007, Water resources data, Oklahoma, water year 2006: U.S. Geological Survey Water-Data Report OK-06-1, 394 p.
Cole-Frowe, Carol, 2007, Water puzzle - State struggles with uneven water supply: Enid News, November 28, 2007 , accessed December 12, 2007 at http://www.enidnews. com/waterstories/local_story_332113854.html/resources_ printstory

Egan, Timothy, 2006, The worst hard time: New York, Houghton Mifflin Company, $340 \mathrm{p}$.

Hoyt, J.C., 1936, Droughts of 1930-34: U.S. Geological Survey Water Supply Paper 680, 106 p.

Hoyt, J.C., 1938, Drought of 1936: U.S. Geological Survey Water Supply Paper 820, 62 p.

Holmes, R.R., Jr., 2008, Drought - Perceptions, effects, and assessment: U.S. Geological Survey, 3 p., accessed February 6, 2008, at http://il.water.usgs.gov/hydro_conditions/ drought_intro.html 
Hutchison, M.A., 2000, Several Oklahoma cities remain flush with plentiful water sources: The Oklahoman, July 24, 2000, accessed July 25, 2000, at http://www.oklahoman. com/cgi-in/shart? ID $=520839 \&$ TP $=$ getarticle

Jackson, Ron, 2006a, Farmers, ranchers feeling drain of persistent drought conditions: The Oklahoman, July 11, 2006, accessed March 6, 2008, at http://www.newsok.com/articles keyword/20006201

Jackson, Ron, 2006b, When will the rain come?: The Oklahoman, January 15, 2006, accessed March 10, 2008, at http://olive.newsok.com/APA26136/PrintArt. asp? SkinFolder $=$ Oklahoman

Jian, Xiaodong, Wolock, D.M., and Lins, H.F., 2007, Streamflow of 2006, water year summary: U.S. Geological Survey, accessed January 10, 2008, at http://water.usgs.gov/waterwa tch/2006summary/\#regional

Johnson, Cullen, 1956, City to buy land for lake: The Oklahoman, December 19, 1956, accessed March 11, 2008, at http://olive.newsok.com/APA26136/PrintArt. asp? SkinFolder=Oklahoman

Knapp, Adam, 2006, Oklahoma under burn ban as wild fires rage across state: About.com, March 16, 2006, accessed March 6, 2008, at http://www.newsok.com/article keyword/1788696

McNutt, Michael, 2006a, Ag department declares state a natural disaster area: The Oklahoman, March 16, 2006, accessed March 6, 2008, at http://www.newsok.com/article keyword/1788696/

McNutt, Michael, 2006b, Gov. issues statewide burn ban: The Oklahoman, August 2, 2006, accessed March 6, 2008, at http://www.newsok.com/article/keyword/2824513

McNutt, Michael, 2006c, Burn ban lifted for some: The Oklahoman, September 13, 2006, accessed March 31, 2008, at http://olive.newsok.com/APA26136/PrintArt. asp?SkinFolder=Oklahoman

Nace, R.L. and Pluhowski, E.J., 1965, Drought of 1950's with special reference to the Midcontinent: U.S. Geological Survey Water Supply Paper 1804, 88 p.

National Agricultural Statistics Service, 2007, Oklahoma agricultural statistics 2007: National Agricultural Statistics Service, $107 \mathrm{p}$.

National Climatic Data Center, 2007a, Statewide monthly total precipitation data, Calendar Year 1895-2006, file drd964x. pcpst.txt: National Climatic Data Center, accessed May 9, 2007, at http://wwwl.ncdc.noaa.gov/pub/data/cirs/drd964x. pcpst.txt
National Climatic Data Center, 2007b, State Climate Division monthly total precipitation data, Calendar Year 1895-2006, file drd964x.pcp.txt: National Climatic Data Center, accessed May 9, 2007, at http://www1.ncdc.noaa.gov/pub/ data/cirs/drd964x.pcp.txt

National Climatic Data Center, 2007c, Climate of 2006, annual review U.S. drought, January 11, 2007: National Climatic Data Center, accessed May 9, 2007, at http://www. hcdc.noaa.gov/oa/climate/research/2006/ann/droughtsummary.htm

National Drought Mitigation Center, 2006a, What is drought? - Understanding and defining drought: National Drought Mitigation Center, accessed September 13, 2006, at http:// www.drought.unl.edu/whatis/concept.htm

National Drought Mitigation Center, 2006b, What is drought? - Drought in the dust bowl years: National Drought Mitigation Center, accessed September 13, 2006, at http://www. drought.unl.edu/whatis/dustbowl.htm

National Drought Mitigation Center, 2007, U.S. Drought Monitor: National Drought Mitigation Center, accessed December 21, 2007, at http://www.drought.unl.edu/dm/ monitor.html

Oklahoma Climatological Survey, 2005, Oklahoma Climate - Winter 2005-2006: Oklahoma Climatological Survey, accessed January 18, 2008, at http://climate.mesonet.org/ seasonal_summary.html

Oklahoma Climatological Survey, 2006a, Oklahoma Climate - Spring 2006: Oklahoma Climatological Survey, accessed January 18, 2008, at http://climate.mesonet.org/seasonal summary.htm

Oklahoma Climatological Survey, 2006b, Oklahoma Climate Summer 2006: Oklahoma Climatological Survey, accessed January 18, 2008, at http://climate.mesonet.org/seasonal_ summary.html

Oklahoma Climatological Survey, 2006c, Oklahoma Climate - Fall 2006: Oklahoma Climatological Survey, accessed January 18, 2008, at http://climate.mesonet.org/seasonal_ summary.html

Oklahoma Climatological Survey, 2008a, Percentage of normal rainfall, water year 2006: Oklahoma Climatological Survey, accessed January 16, 2008, at http://climate. mesonet.org/rainfall/2006waterpct.gif

Oklahoma Climatological Survey, 2008b, Departure from normal rainfall, inches, water year 2006: Oklahoma Climatological Survey, accessed January 16, 2008, at http://climate. mesonet.org/rainfall/2006waterdel.gif

Oklahoma Climatological Survey, 2008c, Drought Monitoring Tools: Oklahoma Climatological Survey, accessed January 18, 2008, at http://climate.mesonet.org/rainfall_update.html 
Oklahoma Water Resources Board, 2005, Oklahoma Water Resources Bulletin and summary of current conditions, December 21, 2005: Oklahoma Water Resources Board, accessed October 5, 2006, at http:///www.owrb.ok.gov supply/drought/pdf_dro/2005/189_1221_2005.pdt

Oklahoma Water Resources Board, 2006a, Oklahoma Water Resources Bulletin and summary of current conditions, October 4, 2006: Oklahoma Water Resources Board, accessed October 5, 2006, at http://www.owrb.ok.gov/ supply/drought/pdf_dro/2006/209_1004_2006.pdf

Oklahoma Water Resources Board, 2006b, Oklahoma Water Resources Bulletin and summary of current conditions, May 24, 2006: Oklahoma Water Resources Board, accessed October 5, 2006, at http://www.owrb.ok.gov/supply/drought/ pdf_dro/2006/200_0524_2006.pdf

Oklahoma Water Resources Board, 2007a, Hydrologic drought of Water Year 2006 - A historical context: Oklahoma Water Resources Board, 4 p.

Slater, Grant, 2006, How DRY can it get?: The Oklahoman, July 2, 2006,accessed March 6, 2008 at http://www.newsok. com/article/keyword/1882166/

Southwestern Power Administration, 2007, 2004-2006 Annual report: Southwestern Power Administration, accessed October 17, 2008, at http://www.swpa.gov/PDFs/SWPA_ FY2004-2006_annual_report.pdf

Sutter, J. D., 2006, Drought continues to wither state: The Oklahoman, September 3, 2006.

Tortorelli, R.L., 2002, Statistical summaries of streamflow in Oklahoma through 1999: U.S. Geological Survey WaterResources Investigations Report 02-4025, $510 \mathrm{p}$.

Tortorelli, R.L., Cooter, E.J., and Schuelein, J.W., 1991, Oklahoma - Floods and droughts, in U.S. Geological Survey, National water summary 1988-1989 - Hydrologic events and floods and droughts: U.S. Geological Survey WaterSupply Paper 2375, p. 451-458.

U.S. Army Corps of Engineers, 2007, Tulsa district water control home page: U.S. Army Corps of Engineers, accessed March 13, 2007, at http://www.swt-wc.usace.army.mil/

U.S. Geological Survey, 2007a, Water watch - Past streamflow conditions - Table of computed median runoff $(\mathrm{mm} /$ day), by water-year, for Oklahoma: U.S. Geological Survey, accessed January 11, 2007, at http://water.usgs.gov/ waterwatch $/ ? m=$ statesum $\& r=o k$
U.S. Geological Survey, 2007b, Automated data processing system (ADAPS), Daily Values Monthly and Annual Statistics (DVMAS): U.S. Geological Survey.

U.S. Geological Survey, 2007c, Drought watch - USGS Streamflow information on drought: U.S. Geological Survey, accessed November 27, 2007, at http://water.usgs.gov waterwatch $/ ? m=p a 07 d \_d r y \& r=o k \& w=p a 07 a \_d r y \% 2 C p l o l$

U.S. Geological Survey, 2007d, National Water Information System, web interface, USGS surface-water daily data for Oklahoma: U.S. Geological Survey, accessed November 27, 2007, at http://waterdata.usgs.gov/ok/nwis/dv/?referred module $=$ sh

U.S. Geological Survey, 2007e, Automated data processing system (ADAPS), Daily Values Daily Summary Statistics (DVDAYSTAT): U.S. Geological Survey.

U.S. Geological Survey, 2007f, National Water Information System, web interface, USGS ground-water daily data for Oklahoma: U.S. Geological Survey, accessed November 27, 2007, at http://waterdata.usgs.gov/ok/nwis/dv/?referred module $=g$ w

U.S. Geological Survey, 2008a, Streamflow of 2006 - Water Year Summary: U.S. Geological Survey, accessed January 10, 2008, at http://water.usgs.gov/ waterwatch/2006summary/

U.S. Geological Survey, 2008b, U.S. Geological Survey Photographic Library, Oklahoma: U.S. Geological Survey, accessed February 22, 2008, at http://libraryphoto. cr.usgs.gov/cgi-bin/search.cgi? search mode=noPunct: free_form $=$ Oklahoma; free form $=$; free_form $=$; free form $=;$ start $=50$

U.S. Geological Survey, 2008c, Water-resources data for the United States, Water Year 2006: U.S. Geological Survey, accessed March 6, 2008, at http://wdr.water.usgs.gov wy2006/search.jsp

U.S. Geological Survey, 2008d, National Water Information System, web interface, USGS ground-water-level daily statistics for Oklahoma: U.S. Geological Survey, accessed October 20, 2008, at http://waterdata.usgs.gov/ok/nwis/ dvstat $/$ referred_module $=g \mathrm{w}$

Vance, Brian, ed., 2007, Oklahoma water atlas: Oklahoma Water Resources Board, $190 \mathrm{p}$. 


\section{Appendixes}




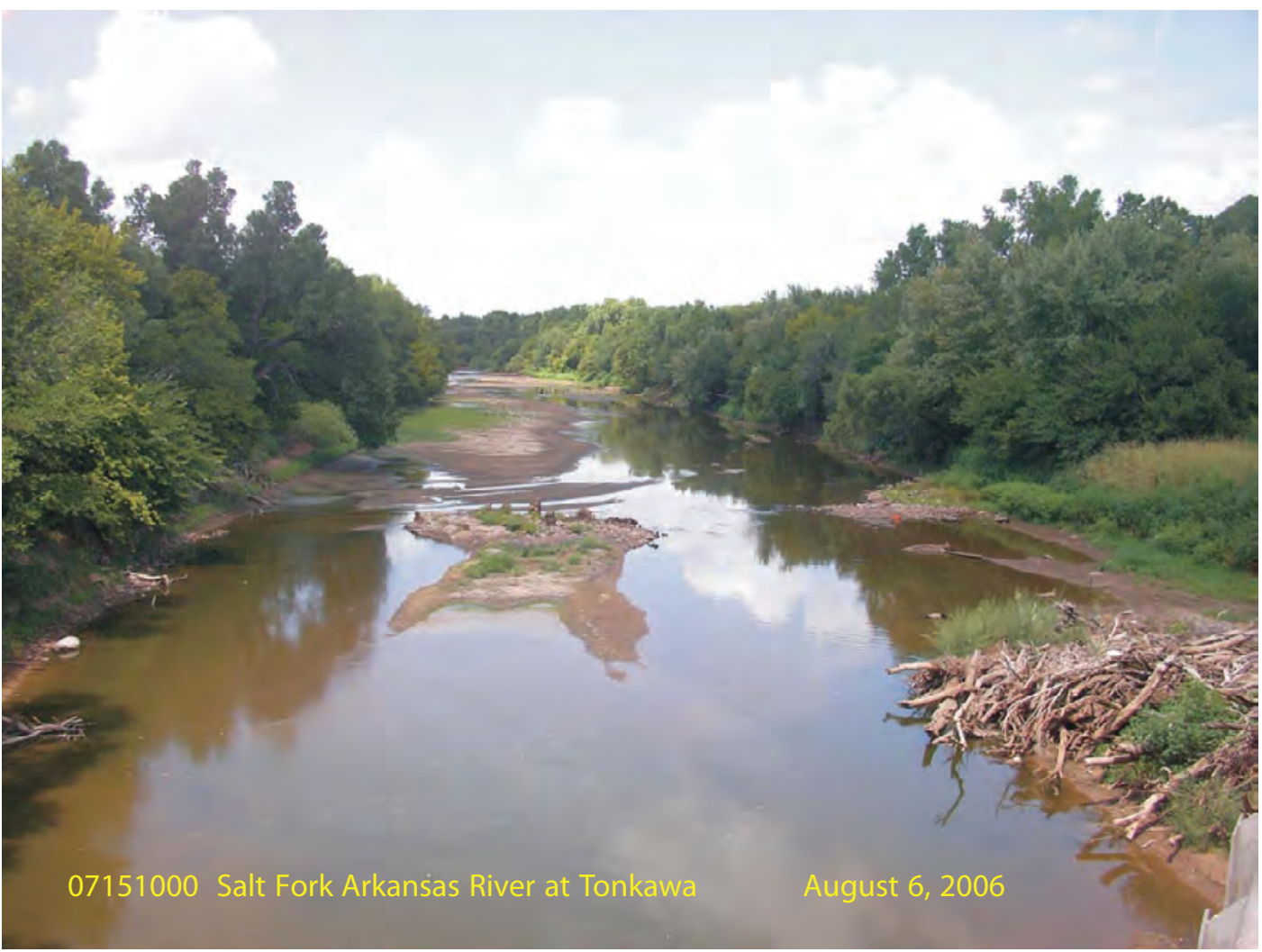

Appendix 1. Salt Fork of Arkansas River at Tonkawa (0751000), showing low flow, 30 cubic feet per second, looking upstream from U.S. Highway 77 bridge, August 6, 2006. Photographer: Jim Norvell, USGS.

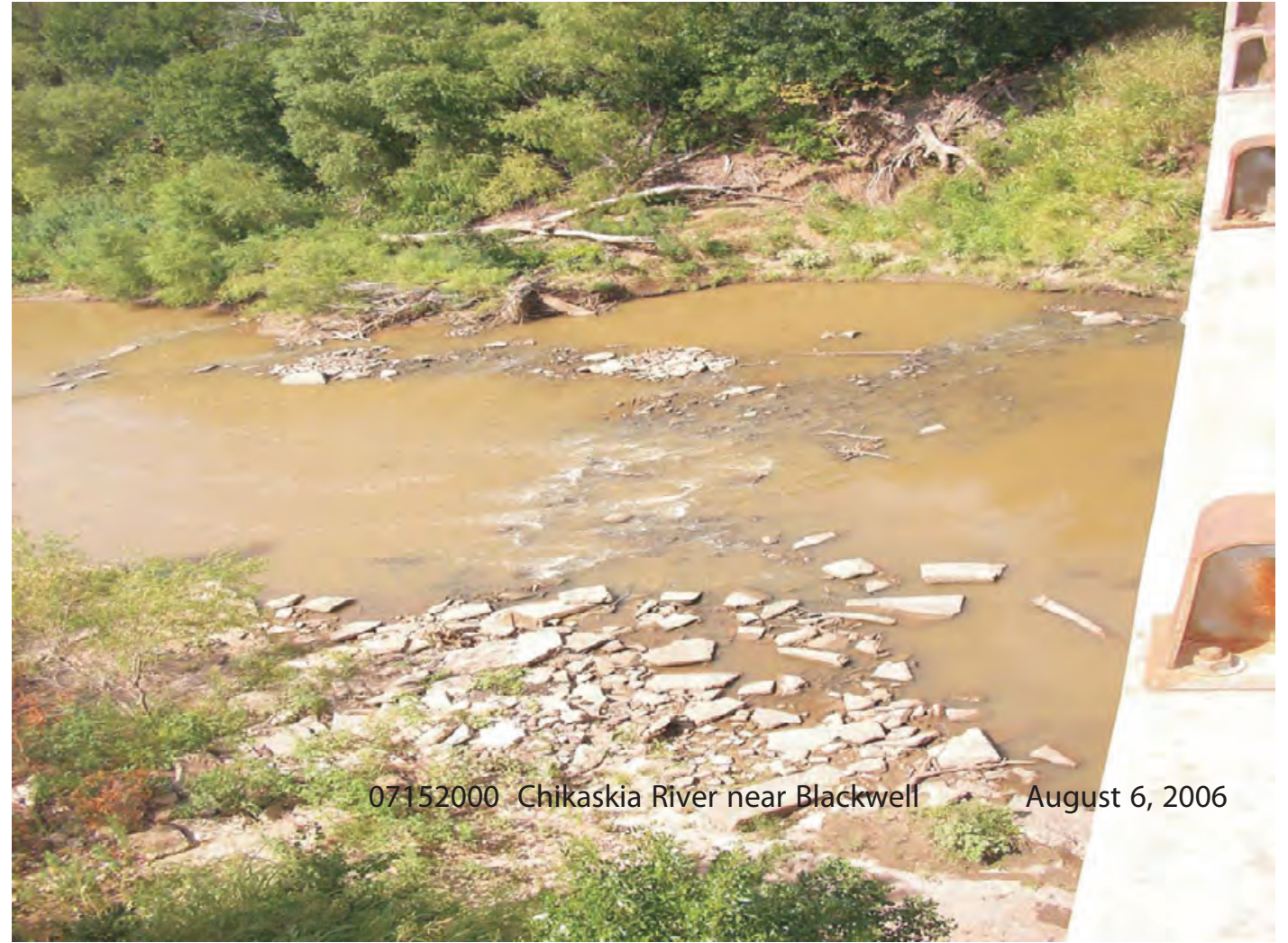

Appendix 2. Chikaskia River near Blackwell (07152000), showing low flow, 74 cubic feet per second, looking downstream from State Highway 11 bridge, August 6, 2006. Photographer: Jim Norvell, USGS. 


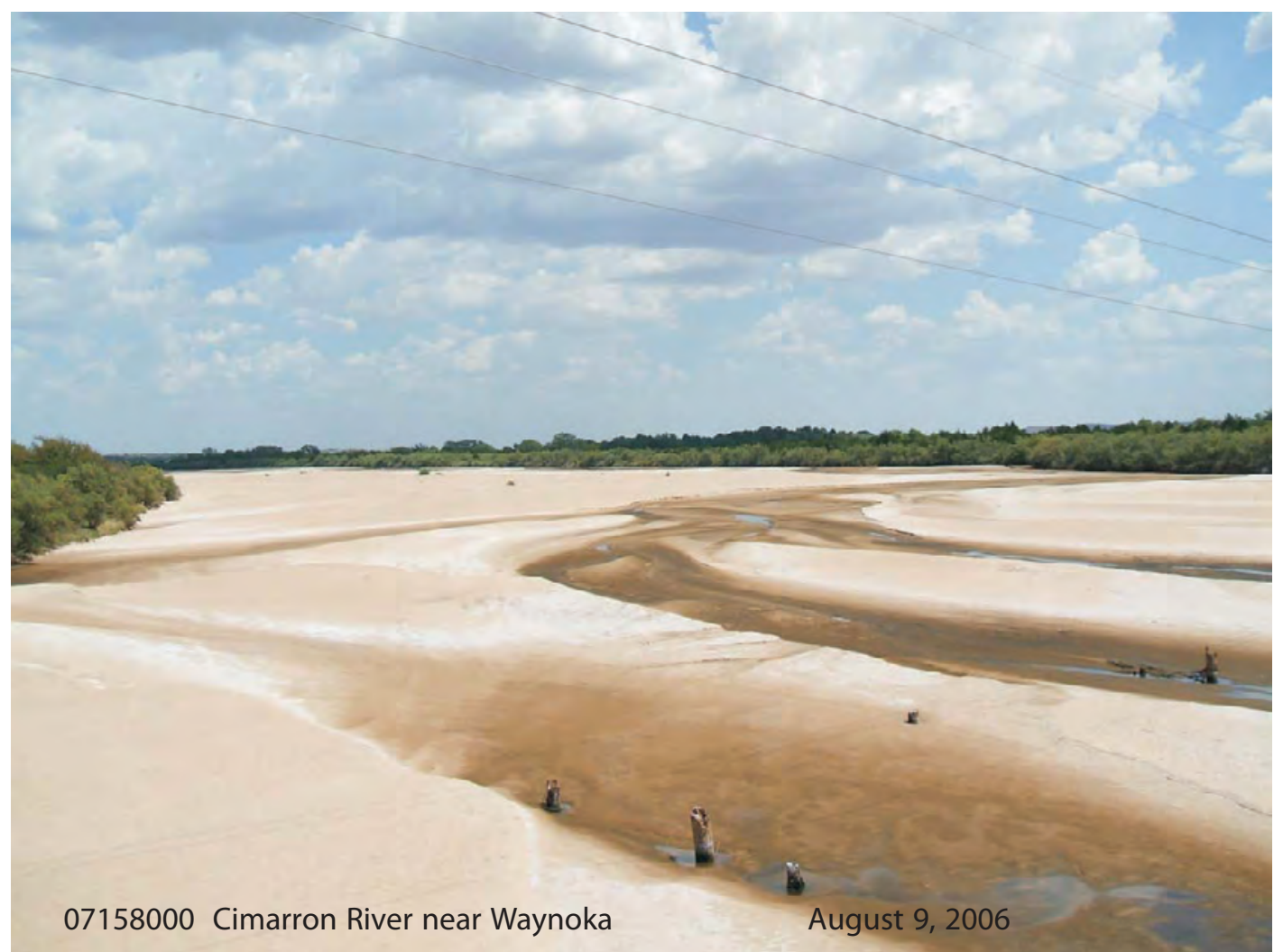

Appendix 3. Cimarron River near Waynoka (07158000), showing low flow, 0.17 cubic foot per second, looking downstream from U.S. Highway 281 bridge, August 9, 2006. Photographer: Marty Phillips, USGS.

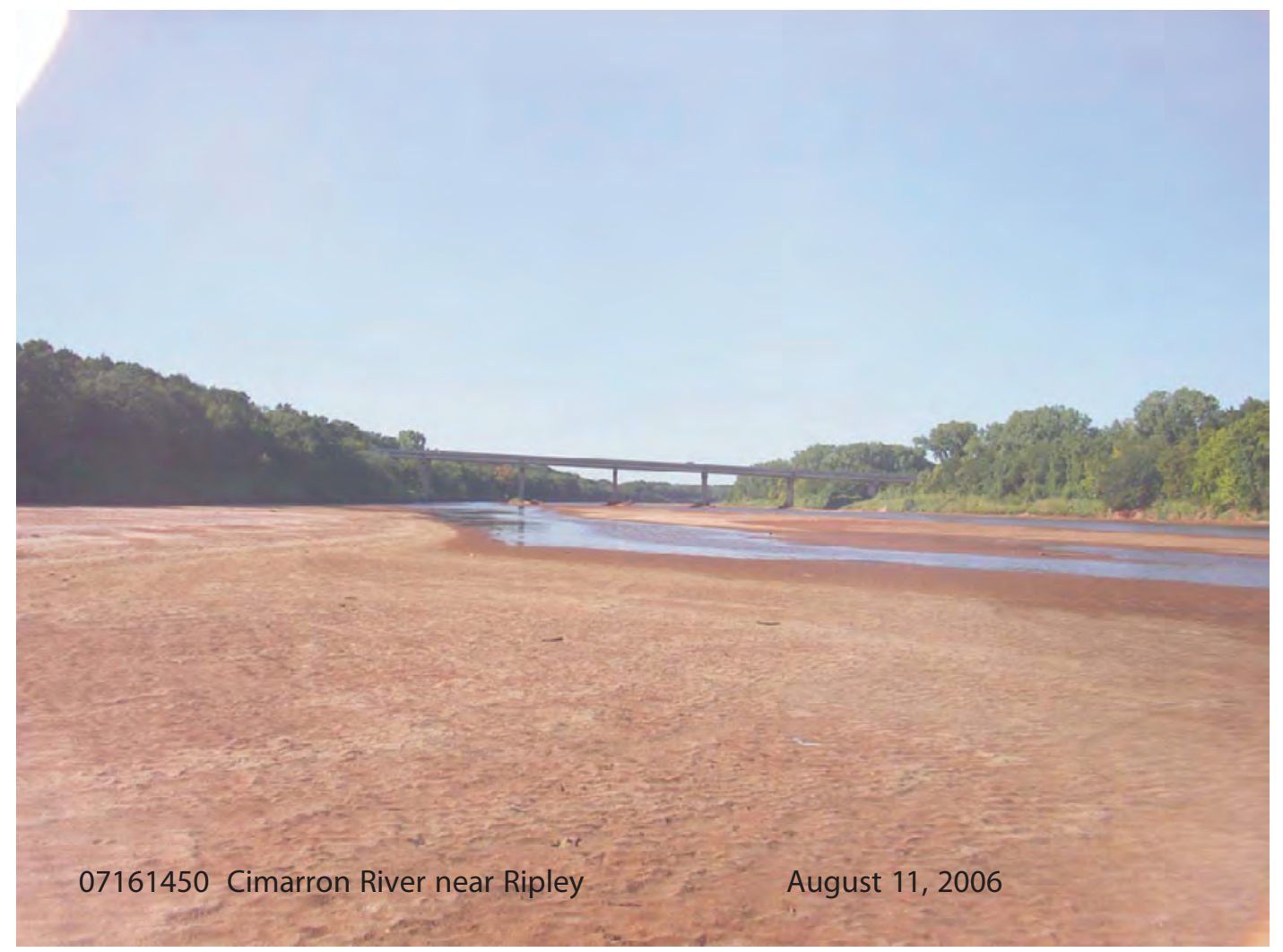

Appendix 4. Cimarron River near Ripley (07161450), showing low flow, 55 cubic feet per second, looking upstream toward State Highway 33 bridge, August 11, 2006. Photographer: Marty Phillips, USGS. 

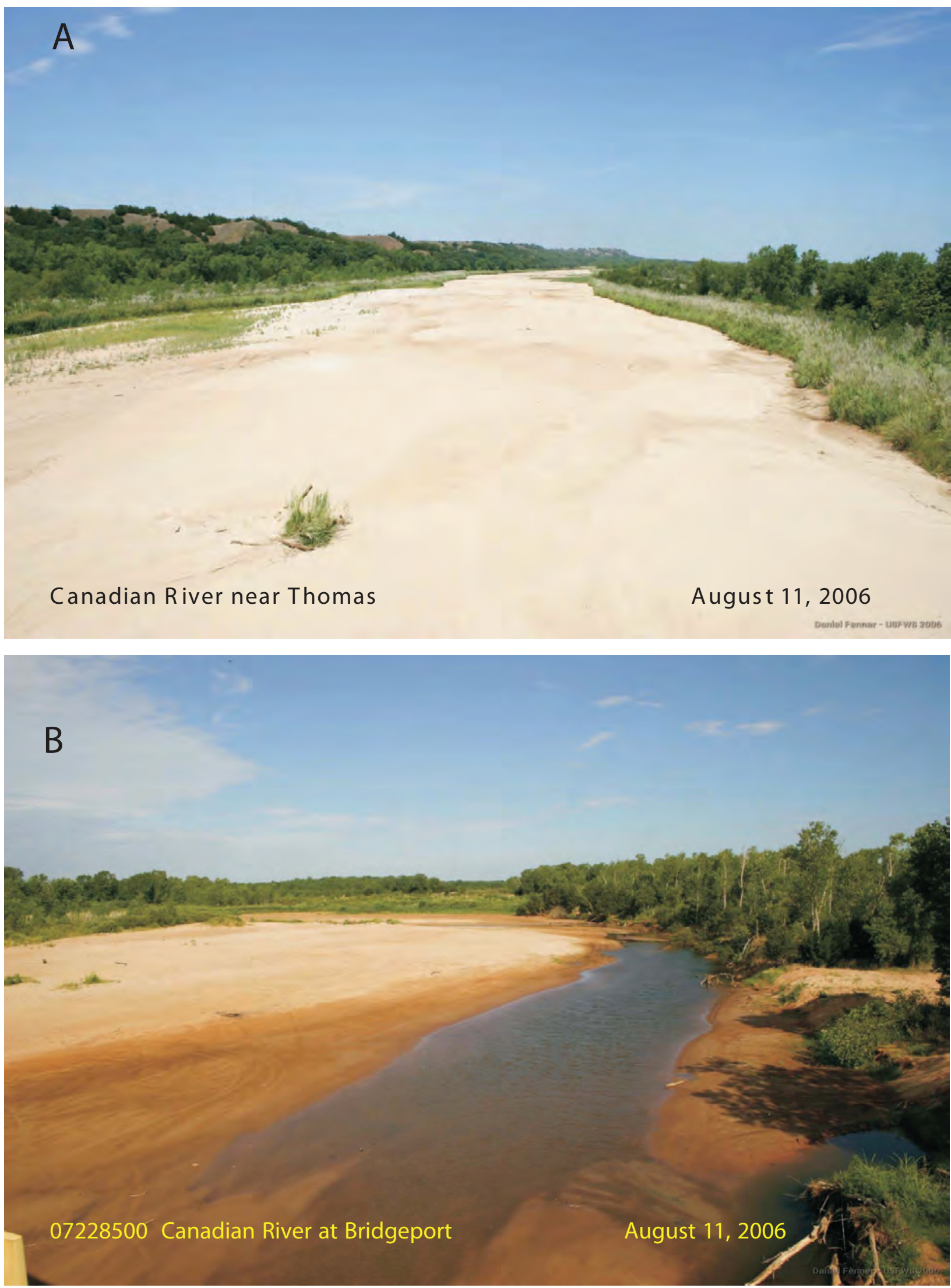

Appendix 5. Canadian River upstream to downstream, August 11, 2006: $(A)$ near Thomas, showing no flow, looking upstream from State Highway 33 bridge $(B)$ at Bridgeport (07228500), showing low flow and pools, 2.9 cubic feet per second, looking upstream from U.S. Highway 281 bridge. All photographs: David Fenner, USFWS, and locations are shown on fig. 9. - Continued 

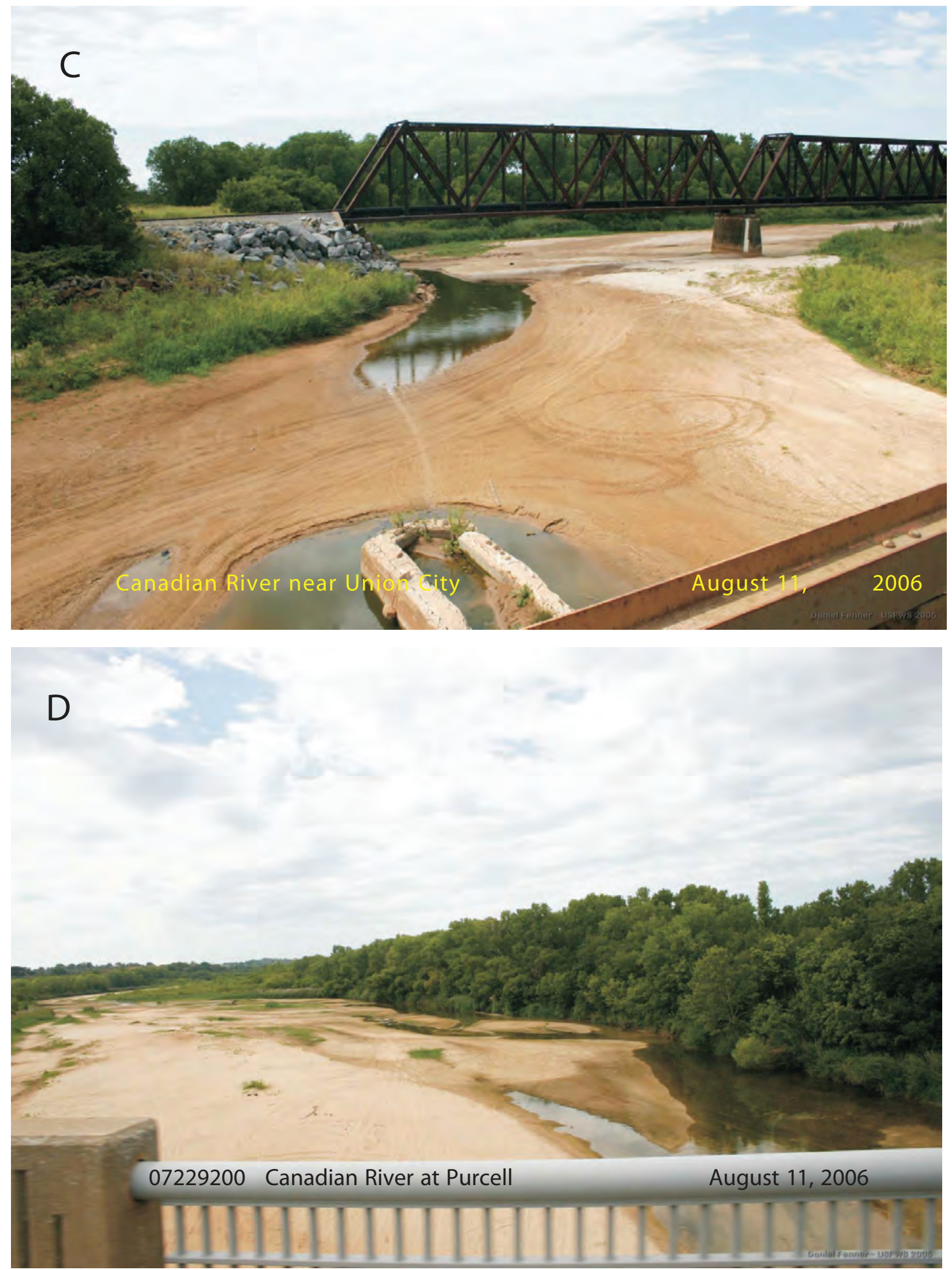

Appendix 5. Canadian River upstream to downstream, August 11, 2006: $(C)$ near Union City, showing no flow and pools, looking upstream from State Highway 81 bridge (D) at Purcell (07229200), showing low flow and pools, 4.2 cubic feet per second, looking upstream from U.S. Highway 77 bridge. All photographs: David Fenner, USFWS, and locations are shown on fig. 9. —Continued 

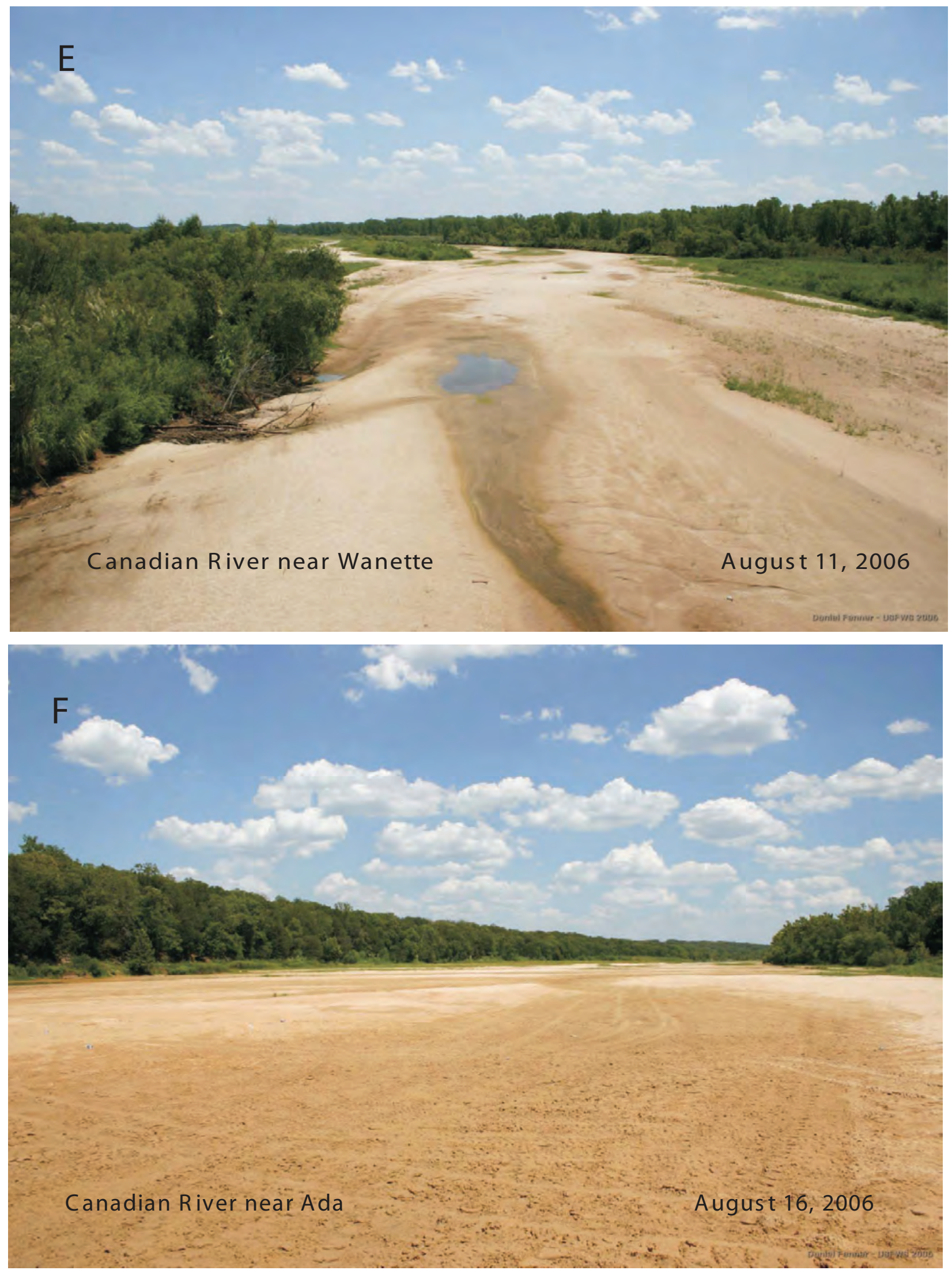

Appendix 5. Canadian River upstream to downstream: $(E)$ near Wanette, showing no flow, looking upstream from State Highway 102 bridge, August 11, 2006 (F) near Ada, showing no flow, looking downstream from State Highway 99 bridge, August 16, 2006. All photographs: David Fenner, USFWS, and locations are shown on fig. 9. 


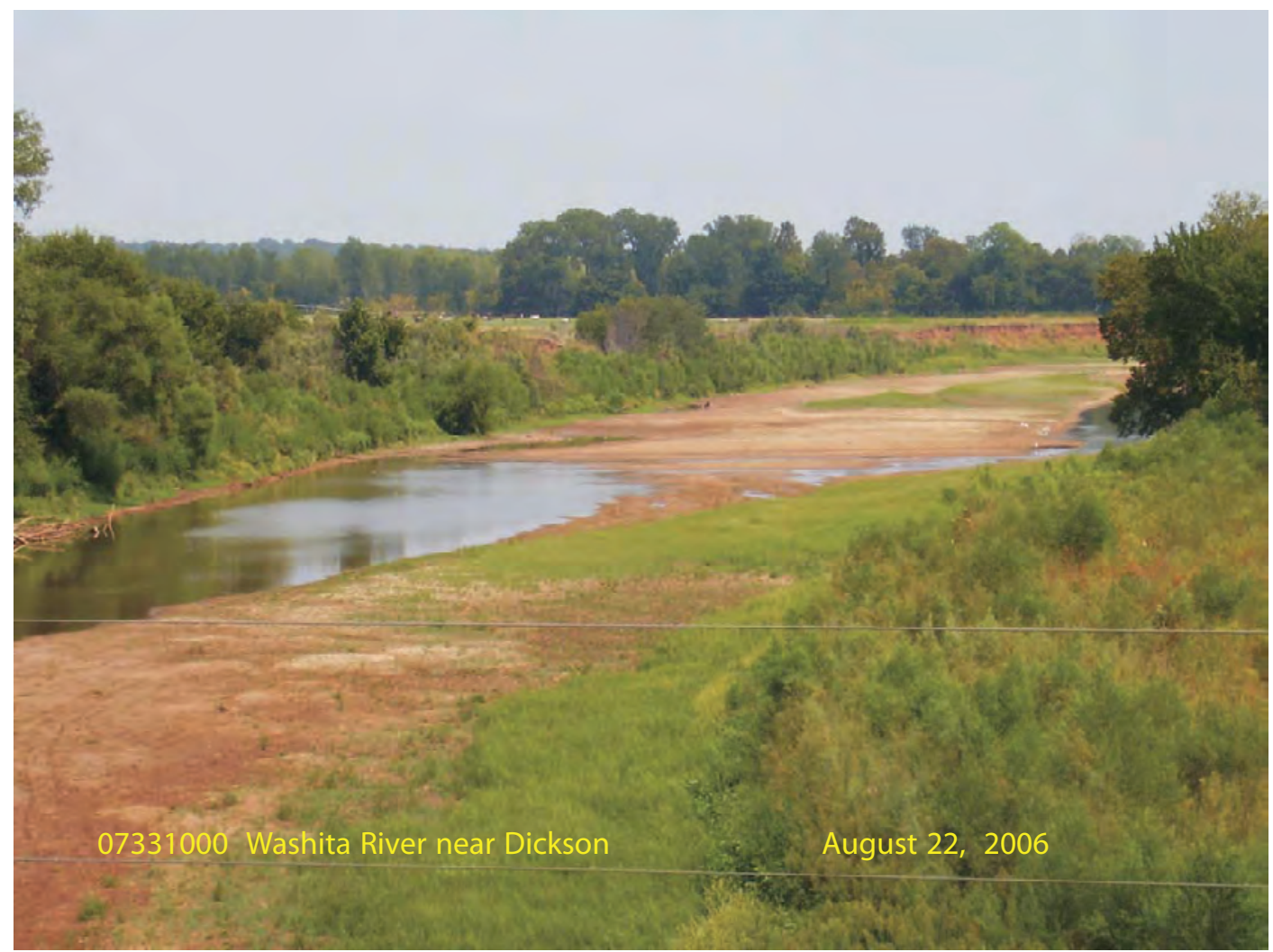

Appendix 6. Washita River near Dickson (07331000), showing low flow and pools, 5.7 cubic feet per second, looking downstream from U.S. Highway 177 bridge, August 22, 2006. Photographer: Ernest Smith, USGS.

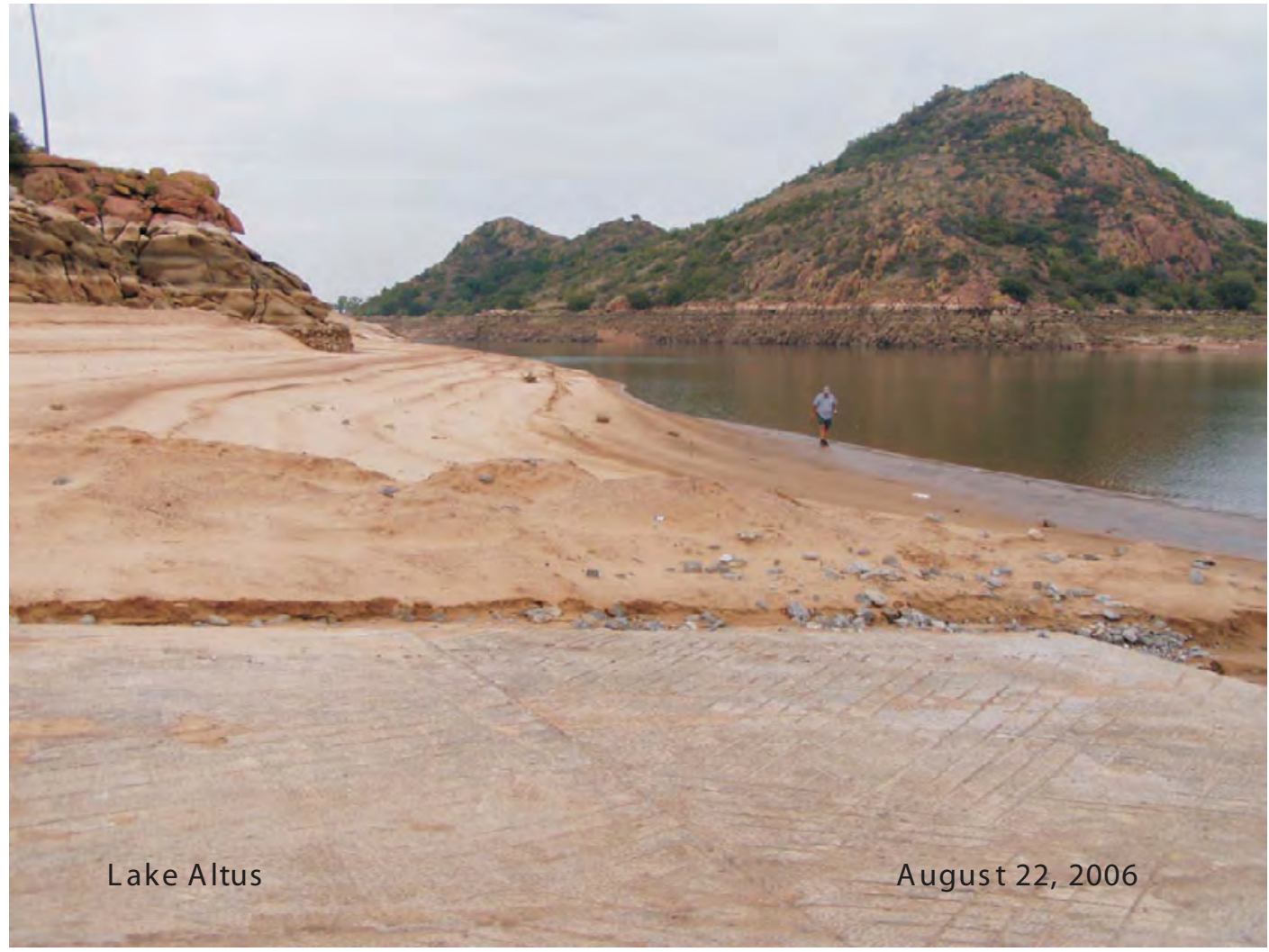

Appendix 7. Lake Altus at Lugert (07302500), showing very low lake elevation, 7.7 percent of conservation storage, looking upstream from dam, August 22, 2006. Photographer: Martin Schneider, USGS. 
Back Cover: Picture of children in the Sam Noble Oklahoma Museum of Natural History summer program walking on Lake Thunderbird's shoreline, Cleveland County, Oklahoma, published July 2, 2006. Photographer: Steve Sisney. Copyright 2006, The Oklahoma Publishing Company.

Publishing support provided by:

Lafayette Publishing Service Center

For more information concerning this publication, contact:

Director, USGS Oklahoma Water Science Center

202 NW 66th St., Bldg. 7

Oklahoma City, OK 73116

(405) 810-4400

Or visit the Oklahoma Water Science Center Web site at: http://ok.water.usgs.gov 


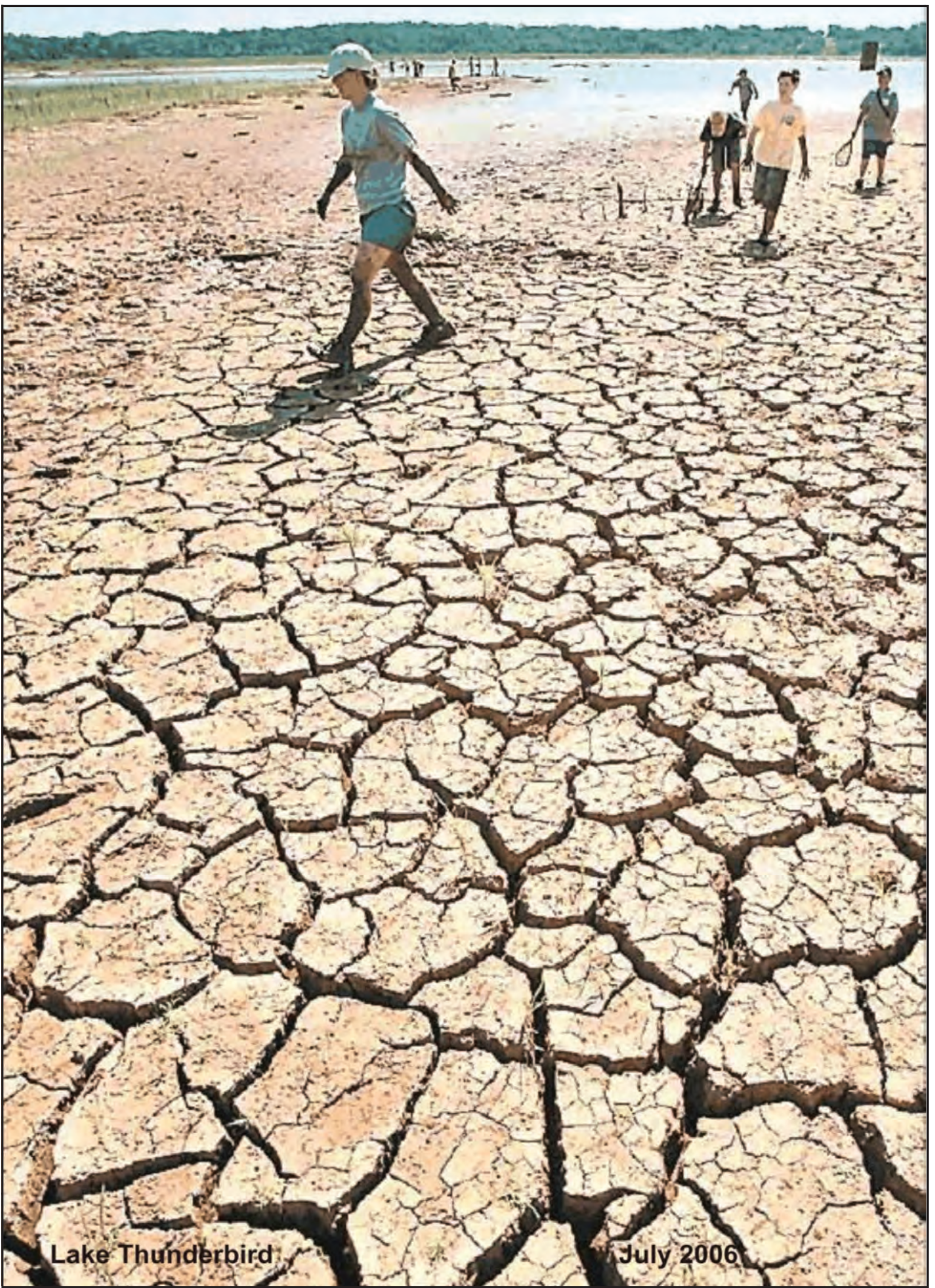

